AUTHORS: Alonso-Blanco, E., Gómez-Moreno, F.J., Artíñano, B., Iglesias-Samitier, S., Juncal-Bello, V., Piñeiro-Iglesias, M., López-Mahía, P., Pérez, N., Brines, M., Alastuey, A., García, M.I., Rodríguez, S., Sorribas, M., Águila, A.D., Titos, G., Lyamani, H., Alados-Arboledas, L.

TITLE: Temporal and spatial variability of atmospheric particle number size distributions across Spain

JOURNAL: Atmospheric Environment, 190, pp. 146-160. YEAR: 2018

DOI: 10.1016/j.atmosenv.2018.06.046 


\title{
TEMPORAL AND SPATIAL VARIABILITY OF ATMOSPHERIC PARTICLE NUMBER SIZE DISTRIBUTIONS ACROSS SPAIN
}

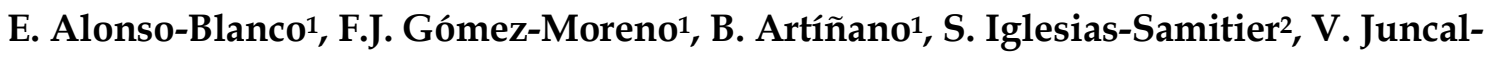

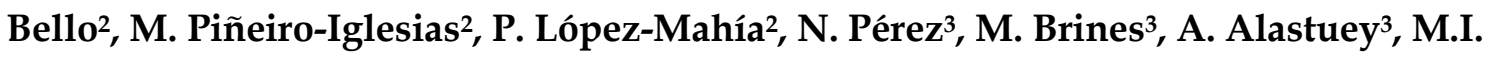
García $^{4}$, S. Rodríguez ${ }^{4}$, M. Sorribas ${ }^{5}$, A. del Águila ${ }^{5}$, G. Titos ${ }^{6,3}$, H. Lyamani ${ }^{6,7}$ and L. Alados-Arboledas ${ }^{6,7}$

[1] Department of Environment Associated Unit CSIC-CIEMAT on Atmospheric Pollution, CIEMAT, Madrid.

[2] Universidade da Coruña, Grupo Química Analítica Aplicada, Instituto Universitario de Medio Ambiente (IUMA), Centro de Investigaciones Científicas Avanzadas (CICA), Departamento de Química, Facultade de Ciencias, A Coruña, Spain.

[3] Institute of Environmental Assessment and Water Research (IDAEA-CSIC), Barcelona, Spain.

[4] Izaña Atmospheric Research Centre, (IARC/CIAI), AEMet, Santa Cruz de Tenerife, Spain.

[5] Atmospheric Sounding Station “El Arenosillo", INTA, Mazagón-Huelva, Spain.

[6] Andalusian Institute for Earth System Research, IISTA-CEAMA, University of Granada, Granada, Spain.

[7] Applied Physics Department, University of Granada, Granada, Spain.

Correspondence to: E. Alonso-Blanco (elisabeth.alonso@ciemat.es) 


\section{Highlights}

Spatio-temporal variability of ultrafine particles at 7 sites in Spain was assessed.

Meteorology and ultrafine particles sources control the site-to-site variability.

Differences in ultrafine particles between inland and coastal sites were documented.

Ultrafine particle bursts influenced the total number concentration in clean areas.

Shrinkages processes were noticed at several sites during the warm period.

\section{Abstract}

This study synthesizes for the first time results from simultaneous aerosol measurements performed at seven diverse locations distributed all over the Spanish geography. The observations were carried out during two field campaigns in 20122013, one-month each and during different seasons. These field campaigns were performed in the framework of the Spanish Network of DMAs (REDMAAS) activities. Measurement sites were grouped as polluted sites (urban background) and clean sites (rural background and high-altitude sites). Seasonal differences were more important at polluted sites, mainly related to meteorology and aerosol sources. Higher total particle concentrations were found during the cold period, driven mainly by Aitken-mode particles (traffic-related aerosol particles). In clean sites, particle concentrations were higher during the warm period. Mild meteorological conditions in combination with the absence of local sources during the cold period make atmospheric nucleation an important contributor to ultrafine particles. These results are reflected in aerosol dynamical processes. Ultrafine particle bursts were frequent in both periods at the clean sites and in the warm period at most polluted sites. Shrinkages processes were identified at three sites (two polluted and one clean site) during the warm period. Meteorology (wind speed and solar radiation) and a highly-volatile aerosol (formed from atmospheric nucleation or traffic emissions) explain this behaviour. Ultrafine particles exhibited a different behaviour at inland and coastal sites. The highest total particle concentrations were observed at coastal 
sites during the warm period. At these sites, the smallest particle modal diameters and the highest variations of particle number size distributions in the smaller particle size range were also found, particularly in the warm period. This may be the result of the high diffusion conditions and mixing of different air masses (clean and polluted) caused by sea-land breezes. Our findings can be explained by the local and regional characteristics of each site, such as meteorology and aerosol sources (types, proximity...) and the influence of meteorology on atmospheric transformation processes.

Keywords: Aerosol dynamical processes, Particle number size distribution, Scanning mobility particle sizer, New particle formation, Nucleation, Aerosol particle shrinkage events.

\section{Introduction}

Atmospheric aerosol particles are one of the most poorly understood components of the Earth's atmosphere (IPCC, 2013). The large diversity of sources, formation and transformation processes give rise to a large number of different aerosol species, and their properties, therefore, are also widely variable. Hence, it is needed to characterize them to know how they behave in the atmosphere to assess, for example, their effects on health and climate. In this regard, aerosol size distribution, i.e. the amount of particles and its physical size, is a critical parameter for health (Sioutas et al., 2005) and climate impacts (IPCC, 2013) studies.

The particle size is directly associated with the risks posed by ambient particulate matter to human health (Heal et al., 2012; HEI, 2013; Rückerl et al., 2011; Tobías et al., 2018). Sub-micrometer aerosol particles enter the human body mainly via inhalation. Many of these particles are deposited in the respiratory tract and others, the smallest particles, make their way until they are incorporated into the bloodstream. In the same way, the particle size plays also a crucial role on aerosol-climate interactions, especially with regard to the direct radiative effect. Small particles scatter more effectively the light per unit mass than larger particles (Seinfeld and Pandis, 2016). 
Furthermore, these have a longer atmospheric lifetime in the atmosphere. Consequently, they may also affect climate via indirect effects such as altering cloud properties (cloud droplet size, concentration...) (Rosenfeld et al., 2008).

Ultrafine particle properties are greatly dependent on their sources and sinks and vary geographically as a function of the land use and atmospheric processing and transport. Thus, the size distribution of the aerosols in the atmosphere at different spatial and temporal scales can be very different as well as their associated effects (Heal et al., 2012).

In-situ measurements of aerosol size distributions are provided by many kinds of instruments based on two principles of operation; light-scattering (Willeke and Liu, 1976) and electric field (Liu and Pui, 1974). Of both of them, the differential mobility analyzer (DMA) used in conjunction with a particle counting system (condensation particle counter (CPC) or electrometers), called Scanning Mobility Particle Sizer (SMPS), is the most common technique employed for long-term characterization of the atmospheric submicrometric aerosol fraction.

Continuous measurements of aerosol size distributions have been analyzed in numerous research studies in diverse locations including high-altitude (Dzepina et al., 2015; García et al., 2014; Herrmann et al., 2015; Rose et al., 2015), remote (Asmi et al., 2016; Järvinen et al., 2013; Kivekäs et al., 2009), rural (Dal Maso et al., 2005; Lihavainen et al., 2016; Shen et al., 2011) and urban (Peng et al., 2017; Wehner and Wiedensohler, 2003; Wu et al., 2008) environments around the globe. However, the current understanding of the spatio-temporal variations of aerosol physical properties in different regions and seasons is still insufficient.

In the European continent, only three relevant studies (Asmi et al., 2011; Beddows et al., 2014; Birmili et al., 2009) have been found in the literature, all of them carried out within the framework of aerosol instrumentation networks. These networks are GUAN (German Ultrafine Aerosol Network) (Birmili et al., 2009), and EUSAAR (European Supersites for Atmospheric Aerosol Research) Network (Asmi et al., 2011; Beddows et al., 2014), the latter included within the Aerosols, Clouds, and Trace 
gases Research InfraStructure (ACTRIS) Network (www.actris.eu), its follow-up project. A similar investigation was conducted in East Asia (Peng et al., 2014). Out of them, only the Asmi et al. (2011) and Beddows et al. (2014), study attributes to meteorological causes the variations observed in the size distribution. However, none of the previous studies included measurements performed in southern Europe where the meteorological conditions are significantly different compared to sites in central and north of Europe.

Numerous works have been devoted to the study of aerosol size distributions in the north of Spain (Iglesias-Samitier et al., 2014), east (Cusack et al., 2013b; Ripoll et al., 2014), centre (Gómez-Moreno et al., 2011), south (Sorribas et al., 2015; Sorribas et al., 2011) and the Canary Islands (García et al., 2014). However, a joint interpretation of the spatial and temporal variability of the particle size distribution in Spain is still lacking.

In 2010, the significant number of Spanish sites monitoring atmospheric aerosol size distributions and the need to exchange scientific and technical information about these measurements promoted the creation of the Spanish Network of Environmental DMAs (REDMAAS) with the participation of the interested research centres. A main purpose was to provide a set of recommendations and unifying criteria concerning instrumentation, calibration and measurement protocols (GómezMoreno et al., 2015). Currently REDMAAS is formed by seven observation sites operated by six research groups.

The REDMAAS activities focussed on not only an annual DMAs intercomparison, but also field campaigns aimed at obtaining representative datasets with spatiotemporal resolution over Spain. For this last purpose, two intensive periods of measurements, one month-long each, with clearly different atmospheric conditions (pollution levels and meteorology), were selected. Simultaneous data sets collected at the seven REDMAAS sites differing in proximity to pollution sources, meteorological characteristics and aerosol dynamical processes have been analysed and results are presented in this work. Thus, the objectives of paper are: (1) to compare particle number size distributions throughout Spain, (2) to evaluate the influence of the 
aerosol sources and meteorology on the sub-micron particles and (3) to study the different aerosol dynamical processes.

A list of the acronyms used for parameters and measurement sites considered in this study is shown in Table S1.

\section{Field campaigns description}

The first campaign corresponded to a warm period (1-30 June 2012), while the second one to a cold period (13 December 2012-15 January 2013). The seven REDMAAS monitoring sites may be considered as representative of most of the environmental conditions in the Spanish territory because of their different geographical position, land uses and pollution sources in the surrounding areas.

\subsection{Measurement Site Descriptions}

The REDMAAS sites have been categorized based on their characteristics and, according to the criteria established by the European Environment Agency (Larssen et al., 1999), in: urban background (UB) (4 sites) and rural background (RB) (2 sites), incorporating for this study a third type of site, one high-altitude (HA) site. The measurement locations are shown in Fig. 1. For the sake of simplicity, in this work UB sites will be referred to as "polluted sites" and RB and HA sites as "clean sites".

A brief description of all the sites from north to south, emphasizing the most significant features of their surroundings is given below:

A Coruña site $\left(\mathrm{ACN}-\mathrm{UB}, 43.3^{\circ} \mathrm{N}, 8.4^{\circ} \mathrm{W}, 45 \mathrm{~m}\right.$ a.s.l. (metres above sea level)): A Coruña is a coastal city in the northwest of Spain with a quarter of a million inhabitants. The climate is Atlantic (Csb as classified by Köppen (Koppen, 1918)). The aerosol measurements were carried out at the urban background site installed at the University of A Coruña, $\sim 1 \mathrm{~km}$ from the coastline. The main anthropogenic sources are the emissions from traffic and domestic activities, but also industrial emissions can influence air quality in the study area. Because of its proximity to the sea, the local wind pattern is mainly driven by the land-sea breeze. North-westerly synoptic winds are dominant and generally carry relatively clean air from the sea, but other 
wind directions are also recorded, with a significant contribution to air pollution levels at this site.

Montseny site (MSY-RB, 41.8 ${ }^{\circ} \mathrm{N}, 2^{\circ}$ E, $720 \mathrm{~m}$ a.s.1.): the MSY-RB site is located inside the Montseny Natural Park, about $40 \mathrm{~km}$ north-northeast from Barcelona city and approximately $25 \mathrm{~km}$ from the Mediterranean coastline. Although the site is relatively far from anthropogenic sources, both industrial emissions and air pollutants from the metropolitan area are transported by mountain breezes, contributing to background particle concentrations at this site. The abundant vegetation that surrounds the site enhance the biogenic volatile organic compounds load, being biogenic aerosol particles a significant contributor to ultrafine particles at this site (Cusack et al., 2013b).

Barcelona site (BCN-UB, 41.4 ${ }^{\circ} \mathrm{N}, 2^{\circ} 1^{\circ}$ E $68 \mathrm{~m}$ a.s.1.): Barcelona is the second largest and most populated city in Spain, around 1,6 million inhabitants. It is located on the northeastern coast of Spain, with a Mediterranean climate. The main pollution source in the Barcelona urban area is road traffic, but other sources such as industrial and harbor activities (anthropogenic) or African dust outbreaks and sea salt aerosol (natural) contribute as well to atmospheric particle pollution. Sea breezes dominate the transport patterns of atmospheric pollution in the city. The experimental site is situated within the university campus in the Institute of Environmental Assessment and Water Research (IDAEA-CSIC). The site is close to one of the largest avenues in the city with a high traffic density.

Madrid site (CIEMAT-UB, $40.5^{\circ} \mathrm{N}, 3.7^{\circ} \mathrm{W}, 657 \mathrm{~m}$ a.s.1.): with just over three million inhabitants, Madrid is the largest city in Spain. In a non-industrial urban context, the urban sources such as traffic and domestic activities are the main atmospheric pollution sources. The Madrid region is surrounded by the Sistema Central mountain range to the north and northeast at approximately $50 \mathrm{~km}$ distance from Madrid city. Consequently, the regional wind pattern is conditioned by the mountain breeze circulation (Art1 $\square$ ñano et al., 2003; Plaza and Artinano, 1994). The climate is Continental-Mediterranean (Csa according to Köppen classification) influenced by urban features. The observations of aerosol size distribution were conducted at the 
urban background site located in the CIEMAT facilities. The site lies $9 \mathrm{~km}$ northnorthwest of Madrid centre and is surrounded by three natural forested areas, Dehesa de la Villa Park ( $0.2 \mathrm{~km}$ away), Casa de Campo Park ( $2.8 \mathrm{~km}$ away) and the Monte del Pardo forest area $(\sim 3.6 \mathrm{~km}$ away). CIEMAT is directly influenced by the urban sources, especially in winter, but also by Saharan dust episodes, especially in summer.

El Arenosillo site (ARN-RB, $37.1^{\circ} \mathrm{N}, \mathbf{6 . 7}^{\circ} \mathrm{W}, 40 \mathrm{~m}$ a.s.1.): El Arenosillo- Atmospheric Sounding Station is a rural background site which belongs to the National Institute for Aerospace Technology (INTA). It is located on the south-west coast of the Iberian Peninsula, inside the Doñana Natural Park, surrounded by typical Mediterranean forest vegetation, and approximately $1 \mathrm{~km}$ to the north-west of the coastline. Two small municipalities of Mazagón ( 10 km Northwest) and Matalascañas ( 22 km Southeast) are found and although there are no local anthropogenic emissions, urban and industrial emissions from Huelva city (about $35 \mathrm{~km}$ ) impact on the regional scale, providing a rather constant aerosol background when air is coming from northwest of the sampling site. During summer, the land-sea breeze circulation is the dominant wind pattern, controlling the particle transport (Sorribas et al., 2015). Air masses with desert dust aerosol contribution are also during February-March and summer months (Sorribas et al., 2017).

Granada site (GRN-UB, 37.2 ${ }^{\circ} \mathrm{N}, 3.6^{\circ} \mathrm{W}, 680 \mathrm{~m}$ a.s.1.): Granada is located in the South of Spain, in the foothills of Sierra Nevada and about $50 \mathrm{~km}$ from the coast. It is a medium-size, around 250,000 inhabitants, and under-industrialized city where the major local aerosol sources are traffic and soil resuspension, more important in the warm season (Lyamani et al., 2010). During winter, domestic heating based on fueloil combustion and biomass burning are additional sources of pollution (Titos et al., 2017). Granada can also be affected by other source regions and long range transport of anthropogenic and natural aerosol such as dust (Lyamani et al., 2010). The site is located to the southwest of the city on the terrace of a two-storey building. Surroundings can be classified as a mixed residential-commercial-traffic area. 
Izaña site (IZAÑA-HA, 28.3 ${ }^{\circ} \mathrm{N}, \mathbf{1 6 . 5}^{\circ} \mathrm{W}, 2367 \mathrm{~m}$ a.s.1.): The Izaña Observatory, operated by the Meteorological State Agency of Spain (AEMET), is located in a remote environment, at high altitude (2367 $\mathrm{m}$ a.s.1.) in Tenerife Island, off North Africa. The site is located above the inversion layer typical of the subtropical region. Izaña is exposed to the westerly winds typical of the North Atlantic (García et al., 2017a), except in summertime, when it is impacted by the dusty Saharan Air Layer (Rodríguez et al., 2015). At night, anticyclonic subsidence and unperturbed free conditions prevails at Izaña, whereas during daylight upslope winds occurs, resulting in the transport of some local aerosol precursor liked to anthropogenic and biogenic sources and new particle formation events (García et al., 2014; García et al., 2017b; Rodríguez et al., 2009).

\subsection{Methodology}

\subsubsection{Instruments and measurements}

Simultaneous measurements of particle number size distributions (PNSDs) were obtained at all described monitoring sites during two campaigns using two different types of measuring instruments. Both are based on the principle of the mobility of a charged particle in an electric field: the scanning mobility particle sizer (SMPS) and the ultrafine particle monitor (UFPM). In both instruments, the aerosol particles are size-selected with a Differential Mobility Analyzer (DMA). However, while the SMPS normally employs a bipolar diffusion neutralizer, in these campaigns a Kr-85 radioactive source, the UFPM uses a corona-jet charger to charge the particles. The SMPS uses a Condensation Particle Counter (CPC) for particle counting and the UFPM an aerosol electrometer.

A total of seven instruments participated in the measurement campaigns: six SMPS (five TSI long-SMPS and one custom-made SMPS IFT (Leibniz Institute for Tropospheric Research, TROPOS) and one TSI-UFPM. A summary of the operation specifications of the measurement equipment at each sampling station is shown in Table S2. 
The consistency of the functioning of the instruments over time has been tested during the intercomparison campaigns of the REDMAAS conducted annually since 2010 (Gómez-Moreno et al., 2015).

The measured range of particle sizes varied from 7.37 to $855.78 \mathrm{~nm}$ depending on the SMPS model and measurement configuration (Table S2). In the case of the TSIUFPM, its measurement size resolution ranged from 20-500 nm into 6 size channels $\left(\mathrm{N}_{20-30}, \mathrm{~N}_{30-50}, \mathrm{~N}_{50-70}, \mathrm{~N}_{70-100}, \mathrm{~N}_{100-200}\right.$ and $\mathrm{N}_{>200 \mathrm{~nm}}$ where $\mathrm{N}$ is the number of particles and its subscript the particle size range). Given that these are different measurement systems (SMPS and UFPM), instrument comparability was discussed in GómezMoreno et al. (2015). The comparison showed that the measured distributions from both instruments are in good agreement. Data acquisition resolution among the different aerosol measurement systems varied from $4.5 \mathrm{~min}$ to $10 \mathrm{~min}$, but they were averaged to $10-\mathrm{min}$ resolution for their comparison.

Corrections of multiple charge and diffusion losses for the instrument and the inlet pipe were done for SMPS systems according to the ACTRIS SMPS standards (Wiedensohler et al., 2012). These have been applied to all SMPS data sets. In the case of UFPM, the kernel matrix applied to the UFPM raw data was the one obtained from factory calibration with ammonium sulphate.

The total concentration of particles $\left(N_{t o t}\right)$ and quantitative contributions to particle number concentrations of the nucleation $\left(N_{n u c}\right)$, Aitken $\left(N_{A i t}\right)$ and accumulation $\left(N_{a c c}\right)$ modes were obtained from the PNSD (Dal Maso et al., 2005). Particles with diameters $<30 \mathrm{~nm}$ were considered the nucleation mode, particles in the range 30-100 $\mathrm{nm}$ the Aitken mode and particles $>100 \mathrm{~nm}$ the accumulation mode. Average mode diameters $\left(D_{\text {mode }}\right)$ were obtained by PNSD fitting to log-normal distributions. As can be seen in Fig. S1 data availability was higher for the cold period (79\% of the total data) than for the warm period $(60 \%)$. Gaps in the measurements were due to instrumental failures or power outages.

Meteorological parameters (temperature $(\mathrm{T})$, relative humidity $(\mathrm{RH})$, precipitation $(\mathrm{P})$, wind speed (WS) and direction (WD), atmospheric pressure, solar radiation (SR)) 
and trace gas pollutants $\left(\mathrm{NO}, \mathrm{NO}_{2}, \mathrm{O}_{3}\right.$ and $\left.\mathrm{SO}_{2}\right)$ recorded at the measurement sites were utilized in the analysis. Table S3 shows available meteorological and gaseous data for all sites during the REDMAAS field campaigns and these can be seen in Fig. S2-S3.

In this study, all the data are presented in UTC time: local time- $2 \mathrm{~h}$ (local time- $1 \mathrm{~h}$ for IZAÑA-HA) in the warm campaign and local time-1h (local time-0h for IZAÑA-HA) in the cold one.

\subsubsection{Particle dynamics analysis tools: New Particle Formation (NPF) and aerosol particle shrinkage events}

NPF and shrinkage events were identified and classified from the PNSD data following the methodologies developed by Dal Maso et al. (2005) and Alonso-Blanco et al. (2017), respectively. The categorization of these aerosol-dynamical processes is summarized in Table 1.

Both methodologies are based on a visual exploration of the daily evolution of the PNSDs using daily contour plots of the size distribution supported by quantitative criteria such as the evolution of condensation sink (CS) and aerosol growth (GR) and evaporation (ER) rates. These aerosol dynamics parameters are of particular interest to understand aerosol physical changes.

The CS is a parameter indicative of the rapidity of condensation of molecules onto available pre-existing particles (Pirjola et al., 1999). Therefore, it is strongly dependent on the particle number concentration and size distribution, i.e. large preexisting aerosol concentrations suppress NPF by consuming condensable vapours. Incomplete measurements of the size distribution may lead to an inadequate estimate of the CS. The contribution of coarse mode particles to the total sink is significant in some environments as coastal ones (Dal Maso et al., 2002). Some studies have found a lower frequency of NPF associated to a higher CS (Engler et al., 2007; Hyvärinen et al., 2008) in these environments. However, other authors have demonstrated that, in some cases, these events were not limited by a high value of CS alone (Kanawade et 
al., 2014; Kulmala et al., 2016; Kulmala et al., 2005; Zhu et al., 2014), but that the availability of precursors determined also their formation. Thus, NPF bursts are the result of the balance between the CS and the availability of the precursors, and this depends on both, the sources and sinks of each specific site. This will be discussed in section 3.4. The CS was calculated according to Eq. 14 in Kulmala et al. (2001) from the measured PNSDs.

GR (+) and evaporation ER (-) were calculated from the $D_{\text {mode }}$ for 10 -min average aerosol size distribution as outlined by Kulmala et al. (2012) during the growth and shrinkage phases respectively.

Finally, the sulfuric acid concentration $\left(\left[\mathrm{H}_{2} \mathrm{SO}_{4}\right]\right)$ in gas phase was estimated by using the general semi-empirical equation constructed by Mikkonen et al. (2011). This gaseous species is involved in NPF events (Riipinen et al., 2007). It is primarily formed by the reaction of $\mathrm{OH}^{-}$and $\mathrm{SO}_{2}$ (Seinfeld and Pandis, 2016), being $\mathrm{SO}_{2}$ emitted mainly by the combustion processes. Details of the equations used have been compiled previously in Alonso-Blanco et al. (2017).

At this point, it must be highlighted that not only $\mathrm{H}_{2} \mathrm{SO}_{4}$ seems to have an important role in aerosol particle formation. A clear association of NPF with highly oxygenated molecules (HOMS), especially those of extremely low volatility organic compounds (LVOCs) of biogenic origin, has been reported recently (Bianchi et al., 2016; Tröstl et al., 2016). This has been documented in previous studies carried out in the different REDMAAS sites, linking NPF episodes to biogenic emissions (CIEMAT-UB: GómezMoreno et al. (2011); ARN-RB : Sorribas et al. (2015); MSY-RB: Cusack et al. (2013b)), occurring mostly during the warm period and related to the presence of biogenic sources near all the sites. This issue will be further discussed in the following section. 


\section{Results and Discussion}

\subsection{Particle number concentration in different size ranges}

Particle number concentrations were evaluated using four different size ranges: $N_{\text {tot }}$, $N_{n u c}, N_{A i t}$ and $N_{a c c}$. The $5^{\text {th }}, 16^{\text {th }}, 50^{\text {th }}$ (median), $84^{\text {th }}$ and $95^{\text {th }}$ percentiles and mean are shown in Fig. 2.

$N_{\text {tot }}$ varied from the warm to the cold period campaign and from site to site (Fig. 2A and B). Thereby, ARN-RB site showed the highest level of $N_{\text {tot }}\left(8.9 \pm 3.7 \times 10^{3} \mathrm{~cm}^{-3}\right)$ during warm period in opposition to the IZAÑA-HA site $\left(8.9 \pm 6.5 \times 10^{2} \mathrm{~cm}^{-3}\right)$, while in the cold period this situation corresponded to GRN-UB $\left(11.8 \pm 4.7 \times 10^{3} \mathrm{~cm}^{-3}\right)$ and IZAÑA-HA $\left(5.2 \pm 3.6 \times 10^{2} \mathrm{~cm}^{-3}\right)$ sites respectively (Table S4). Depending on $N_{\text {tot }}$ sites were classified in two different groups of sites. At RB and HA sites (clean sites), $N_{t o t}$ concentrations were 1-2 times higher in summer than in winter. $N_{n u c}$ was responsible for the high PNC measured in the summer period ( $50 \%$ of the $\left.N_{t o t}\right)$. This result can be expected for sites with no direct emissions nearby (von Bismarck-Osten et al., 2013; Zíková and Ždímal, 2013). Photochemical production of particles at MSY-RB and IZAÑA-HA sites may be responsible for this situation. In the case of ARN-RB, not only the photochemical production contributed to the $N_{n u c}$ but also the transport of accumulated particles offshore to the site during the non-pure breeze circulation (Sorribas et al., 2011). For UB sites, the lack of data for BCN-UB and GRN-UB during the warm period led to only data from two sites was comparable between the two field campaigns, CIEMAT-UB and ACN-UB. Both sites exhibited opposite behaviour to each other. CIEMAT-UB site recorded the highest $N_{\text {tot }}$ during the cold period. In this case, $N_{t o t}$ was dominated by $N_{\text {Ait }}$, being attributed to traffic-related emissions. Conversely, ACN-UB presented a similar behaviour than clean sites, being $N_{n u c}$ the main contributor to the $N_{\text {tot }}$ for both periods. In this site, and as it happens for other coastal areas (Fernández-Camacho et al., 2010), the local circulations associated with the sea breezes controls pollutant transport. Thus, at ACN-UB, $N_{\text {tot }}$ was mainly affected by emissions from industrial plants and ships during the warm period (Fig. S4 shows that the highest $N_{n u c}$ were observed mainly with northern and western 
winds, coinciding with high values of $\mathrm{SO}_{2}$ ), while during the cold period $N_{\text {tot }}$ was affected by traffic emissions (Fig. S5 shows that $N_{\text {tot }}$ were observed with southern and western winds, coinciding with high values of $\mathrm{NO}$ and $\mathrm{NO}_{2}$ ). $\mathrm{N}_{\text {acc }}$ was the lowest contributor to $N_{\text {tot }}$ at all sites for both periods. $N_{\text {tot }}$ showed a clearly different behaviour between inland and coastal sites. Coastal sites registered the highest concentrations in the warm period, while in the cold period this situation was the opposite. This was in large part due to the effect of the sea breeze circulation on the pollutant transport (Tsai et al., 2011), particularly coastal industrial and ship emissions.

In comparison with others studies, mean $N_{\text {tot }}$ found in this study for urban sites (Table S4) was much lower, 1-9 times, than those reported for urban areas of China (Peng et al., 2014), much more populated and industrialized than the Spanish cities analysed in this study. However, our values are closer to other American (Masiol et al., 2018; Wang et al., 2011; Wang et al., 2012) and European sites (Birmili et al., 2009; von Bismarck-Osten et al., 2013), where environmental policy is more restricted. Focusing on Europe, for RB sites, values reported in literature vary widely; some examples are Ispra $\left(1.0 \times 10^{4} \mathrm{~cm}^{-3}\right.$; Rodríguez et al., 2005), some rural areas of Germany (4.0-6.0×10 $\mathrm{cm}^{-3}$; Birmili et al., 2009) or the Czech Republic $\left(1.0 \times 10^{3} \mathrm{~cm}^{-3}\right.$; Schwarz et al., 2016). In general, concentrations registered in this study were more similar to those measured in Central Europe, but seasonal effects are as marked as those found in Northern Europe (Asmi et al., 2011). IZAÑA-HA is a high-altitude site and presented a behavior similar to that observed in other mountain areas in Europe (Asmi et al., 2011), i.e. lower concentrations in winter and greater in the warm period (Table S4). This behavior is typically recorded at high-altitude sites as Jungfraujoch (Switzerland) (Herrmann et al., 2015) or Mount Waliguan (Kivekäs et al., 2009).

Whiskers plots in Fig. 2A show a large variability of $N_{\text {tot }}$ during the warm period at the clean sites and ACN-UB. This is due to day-to-day PNC variations associated mainly to the contribution of $N_{n u c}$ to the $N_{t o t}$. In the cold period, all sites presented strong PNC variations (Fig. 2B). Primary ultrafine particles attributed to traffic and domestic emissions in the polluted sites and particles nucleated in the atmosphere or 
from the coastal and regional industrial emissions in the clean sites were responsible for this situation. In both periods, IZAÑA-HA site showed the greater variability of PNC because its main source of ultrafine particles was atmospheric aerosol nucleation (García et al., 2014). Although, the measured size ranges were different for each site (Table S2), following sections support these interpretations.

\subsection{Particle number size distributions and related parameters}

The mean PNSD and the three percentiles $\left(16^{\text {th }}, 50^{\text {th }}\right.$ (median) and $\left.84^{\text {th }}\right)$ are represented in Fig. 3 for each of the stations participating in this study during both the warm and cold field campaigns. The medians of the PNSDs for each field campaign were fitted to lognormal functions. Statistics for these fittings are given in Table 2. The influence of aerosol sources and meteorology on the structure of PNSDs was evidenced. In both periods, practically all the sites presented bimodal structures (Fig. 3), suggesting a mixture of particles of different origin. The $D_{\text {mode }}$ of the finer mode was slightly smaller in the warm period $(15.0-47.6 \mathrm{~nm})$, which could be explained by the enhanced nucleation favoured by the intense solar radiation and an increased atmospheric mixing depth (higher dilution and dispersion of condensable vapours (Zhu et al., 2004)). Considering both periods, the second mode varied widely between 44.6 and $181.1 \mathrm{~nm}$, finding, in general, that $D_{\text {mode }}$ was higher for clean sites (Table 2).

In the warm period, clean sites and ACN-UB presented a major peak in the 15.0-55.3 $\mathrm{nm}$ range. This was mainly due to the impact of the nucleation-mode particles from the atmospheric production of particles or from the coastal and regional industrial emissions in coastal sites. CIEMAT-UB only showed a peak centred in $45.0 \mathrm{~nm}$ favoured by a well-mixed atmosphere (Gómez-Moreno et al., 2011). The increase of combustion processes (heating) and the accumulation of aerosols due to a higher atmospheric stability during the cold period resulted in a clear bimodal structure for polluted sites. Regarding clean sites, PNSDs showed a unimodal structure at ARNRB and a bimodal structure at MSY-RB and IZANA-HA sites. In the first case, the accumulated offshore particles transported at site and a strong background of aerosol 
particles were responsible for this behaviour while in the second case it was attributable to the contribution of atmospheric nucleation, mainly at IZAÑA-HA. In general, coastal sites presented a relatively smaller $D_{\text {mode }}$ during both periods, possibly favoured by great diffusion conditions caused by sea-land circulation and the impact of the coastal and regional industrial emissions.

It should be highlighted the much higher values of $84^{\text {th }}$ and mean vs $50^{\text {th }}$ percentile for those sites whose daily cycle is mainly prompted by photochemical induced nucleation (a high aerosol number concentration in short time periods), especially in IZAÑA-HA (Fig. 3). In ARN-RB, this is not only caused by nucleation atmospheric but also by nucleated particles moved offshore towards the land during non-pure breeze pattern that impact on $N_{n u c}$ at noon (Sorribas et al., 2011). The same situation was also found in ACN-UB, although by contribution of coastal industrial emissions to the $N_{n u c}$. Thus, the greatest amplitude was found for the smallest size ranges, in agreement with Zíková and Ždímal (2013). This effect was more pronounced for coastal sites in the warm period, where aerosol particles result from mixing between polluted and clean air caused by the sea-breeze circulation (Piazzola et al., 2012).

The daily evolution of particle number and size is plotted in Fig. 4. In polluted sites the PNSD daily pattern was mainly influenced by local sources in the cold period (Kanawade et al., 2014; Peng et al., 2014). Thus, as can be seen in Fig. 4, two concentration peaks associated with local traffic emissions were observed, one of them in the morning ( 08:00 UTC) and the other one in the evening ( 21:00 UTC). Aging of ambient particles during periods of atmospheric stability (i.e. weaker vertical mixing) resulted in high PNC for larger diameters in CIEMAT-UB. Thus, $N_{a c c}$ was higher for this period ( 2 times) (Table S4) than during the warm period. This behaviour has already been observed in cities such as Milan, Barcelona and London (Rodríguez et al., 2007). The daily variations of the meteorological parameters and trace gases in polluted sites support these results (Fig. S3 and S5). The $\mathrm{NO}_{\mathrm{x}}$ concentration showed a similar behaviour than $N_{\text {tot }}$ when winds were from the urban agglomeration. However, in the warm period the anthropogenic impact on ultrafine particles was lower than in the winter period, making the influence of meteorology 
more evident. Thus, aerosol transformation processes were more frequent during the warm period as it will be shown in the section 3.4. So, in the CIEMAT-UB site a third peak appeared at noon due to photochemical production. At ACN-UB site the daily pattern was more typical of clean sites (Fig. 4). The frequent presence of sea-breezes in this site, especially in the warm period (Iglesias-Samitier et al., 2014), seem to be responsible for this situation (see Fig. S2), smoothing the urban effects. This situation is common for urban areas located in the coastal proximity (Babu et al., 2016).

In clean areas, without the direct impact of anthropogenic local sources of aerosol particles, the meteorology influence on the daily pattern was more evident. Thus, these data showed a pronounced aerosol particles peak around midday due to the photochemical production in both campaigns. However, the contribution of background aerosol load at clean sites led to changes in $D_{\text {mode. }}$ In ARN-RB and MSYRB, contrary to the IZAÑA-HA site, the amount of background aerosol loading from transport processes of regional emissions was quite large, especially in the cold period when $\sim 70 \%$ of the PNC corresponded to $N_{A i t}+N_{a c c}$ (see section 3.3 and Fig. S4S5). In both sites, the $D_{\text {mode }}$ was significantly greater in the cold period, reinforcing the previous results (Table 2). The aging of ambient particles during the transport from regional sources seems to explain this fact (Rodríguez et al., 2005).

\subsection{Weekend-weekday effect assessment}

The difference between workdays (Monday-Friday) and weekends (SaturdaySunday) was explored in order to assess the role of local and regional emission sources on aerosol concentration. The spatial and temporal variation of PNSDs and their PNCs for workdays (WKs) and weekends (WEs) can be seen in Fig. 5 and S6 respectively.

In general, a similar shape of the particle size distribution was found at each site for both WKs and WEs (Fig. 5). However, some changes in the particle concentrations and $D_{\text {mode }}$ were observed (Table 2). In the warm period, the increase in the atmospheric mixing depth smoothed the variations between WKs and WEs. In clean sites and ACN-UB site $N_{\text {tot }}$ was higher during WEs with respect to WKs mainly due 
to a small increase in $N_{n u c}$ (Table S5) possibly promoted by the reduction in pollutant concentration from regional sources, favouring NPF. Especially remarkable was the case of IZAÑA-HA, where $N_{n u c}$ was $\sim 2$ times higher during the WEs than the WKs (Table S5). This seemed to be related to the predominant easterly winds during the WEs, sector associated with a higher frequency of NPF at this site (García et al., 2014). In CIEMAT-UB, $N_{\text {Ait }}$ and $N_{a c c}$ were slightly smaller during WEs. Here, the reduction of traffic emissions during WEs was responsible of this effect, clearly evident in the cold period. This is characteristic of this site, influenced by traffic when the wind comes from the urban agglomeration as has been described for other suburban sites (Väkevä et al., 2000; Wiedensohler et al., 2002). Modal peak diameters were higher for clean sites and ACN-UB in opposition to CIEMAT-UB, however variations in $D_{\text {mode }}$ were less pronounced.

Conversely, during the cold period, particularly at UB sites, the highest PNCs were usually observed during WKs, also observed in Asmi (2012). D mode suffered a slight shift towards lower values during WEs, being the concentration of the first modal peak lower during the WEs than during the WKs (30-60\%). These changes are clearly evidenced in the daily pattern of PNCs (Fig. S6). Thus, this was relatively smooth during WEs, especially in the morning and afternoon rush hours, suggesting that the traffic emissions are an important contributor to the ultrafine particles in these sites. In WEs, for clean sites, mean $N_{\text {tot }}$ was also lower than during WKs, however only in ARN-RB and MSY-RB $N_{n u c}$ increased. Although NPF events occurred under clean and polluted conditions in both sites as will be discussed in the section 3.4, a reduction of the aerosol background concentration might be responsible for this fact.

\subsection{Aerosol-Dynamical Processes: NPF and Shrinkage Events}

Meteorological factors such as high temperature and solar radiation (Ma and Birmili, 2015) and low relative humidity (Hamed et al., 2011) and changes in local recirculation patterns create a complex environment for aerosol and reactive gas processes. All these conditions were prevalent during the warm period (Table S6). Also, the phenological stage of the vegetation tends to be more active under high 
solar radiation and temperature, with the consequent contribution of biogenic precursors to the atmosphere (Hakola et al., 2003).

NPF were identified at all sites with the exception of ACN-UB. Since there are no data available for BCN-UB and GRN-UB during the warm period, more frequent period of NPF events, their occurrence and parameterization has not been possible to evaluate it. The evolutions of the CS and the nucleation/Aitken-modes particles (shifts of the size distribution to larger sizes) observed during NPF events in this study are typical of these processes (Guo et al., 2012; Wang et al., 2014). The number of events varied widely from one site to other. The occurrence of these processes depends on the distribution of pollution sources and meteorology. Thus, the number of days with nucleation events tends to be greater in rural and remote areas than in urban backgrounds (Fig. 6), not identifying NPF episodes in these latter areas during the cold period. About 50-80\% of all the days with available data were NPF eventdays at the MSY-RB, IZAÑA-HA and CIEMAT-UB sites during the warm period. ARN-RB site only recorded 19\% of NPF event-days for the same period. In this last site, the wind direction is the most important variable influencing the NPF event frequency (Sorribas et al., 2011). During warm period, the sea-land breeze pattern can develop, and it is lower the frequency of wind blowing from areas with predominance of biogenic emissions. It produces a decrease in NPF frequency. In the cold period, the highest frequency of NPF events occurred at IZAÑA-HA site $(71 \%$ of the days), with a high solar radiation levels (Table S6) due to the combination of low latitude and high altitude, followed by ARN-RB (30\%) and MSY-RB (24\%). With the exception of ARN-RB site, the NPF average duration was longer in the warm period compared to the cold one, indicating a well-defined particle growth. Examples of NPF events can be seen in Fig. 7.

When NPF episodes occurred, air masses came most frequently from green areas (NE to $\mathrm{W}$ air masses in CIEMAT-UB, NNE air masses in ARN-RB and $\mathrm{S}$ (in the warm period) and $\mathrm{N}$ (in the cold period) relatively calm winds in MSY-RB) (Fig. S7). This point to a greater possibility for high biogenic vapour load contributing to aerosol formation and growth processes, agreeing with previous studies carried out at these 
sites (CIEMAT-UB (Gómez-Moreno et al., 2011), MSY-RB (Cusack et al., 2013b) and ARN-RB (Sorribas et al., 2015)). In IZAÑA-HA, NPF episodes occurred mostly when air masses originated from westerly to easterly directions (in the warm period) and south-easterly (in the cold period), sectors with high $\mathrm{SO}_{2}$ concentration (García et al., 2014) (Fig. S4-S5). A more detailed description of the main aspects of NPF episodes in this last site can be found in García et al. (2014).

As already mentioned above, particle formation hardly occurs with high aerosol background concentration. However, ARN-RB is a site to be highlighted in this respect. Although a pre-existing background aerosol made difficult the nucleation of precursors, being the type Ib, II (described in Table 1) or non-event day, here, some well-formed NPF episodes were found in both periods (see example in Fig. 7B). In these cases, a permanent large-size aerosol background for the whole day was common. Thus, CS was usually higher than under clean conditions and remained relatively constant during these episodes and the previous two hours $\left(1.0-1.5 \times 10^{-2} \mathrm{~s}^{-}\right.$ $\left.{ }^{1}\right)$. In these conditions, their occurrence may be attributed to two factors: i) aerosol background cannot grow by condensation of organics vapour and these are therefore available in the atmosphere and ii) aerosol-forming precursors are high enough to induce particle burst episodes during the solar radiation peak. ARN-RB is in the protected area of Doñana Natural Park and near the Doñana National Park with 108,086 hectares of cover forest in total. For that, it is expected high aerosol precursors of biogenic origin. Moreover, the implication of anthropogenic precursors cannot be discarded due to this forest area is located in the mouth of the Guadalquivir valley. This valley can be a reservoir of industrial or population centres depending on time of year and air flow patterns. Some previous studies have reported NPF episodes in polluted air masses (Kulmala et al., 2005), in which the presence of high enough concentration of precursors in combination with a strong atmospheric oxidation capacity seems to be the cause of their formation (Kulmala et al., 2005). Also, this situation was found some days for MSY-RB. However, in this last case the input of polluted air throughout the day was lower. 
Interestingly, shrinkage events have been identified at the CIEMAT-UB, ACN-UB and ARN-RB sites during the warm period. The main characteristics for each event identified are presented in Table S7. Shrinkages belonging to the three types (NPF+S, $\mathrm{G}+\mathrm{S}$ and P-S, 2 cases for each type identified) are represented in CIEMAT and NPF+S (1 case) and P-S (13 cases) in ARN-RB, while only one P-S event in ACN-UB (see Table 1 for a detailed description of each type). These events were observed in the second half of the day at the three sites. An increased wind speed, high temperature or reduced photochemical activity may be the cause of the phenomenology of these processes (Alonso-Blanco et al., 2017 and reference therein). These three factors may result in the displacement of low-volatile vapours from the particle to the gas phase, and consequently the particle size can be reduced (Robinson et al., 2007). In CIEMAT it has been demonstrated that a high wind speed associated with a mountain breeze pattern and the reduction of photochemical activity cause these processes (AlonsoBlanco et al., 2017). The phenomenology of shrinkage events identified at the CIEMAT-UB site has been analysed in detail by Alonso-Blanco et al. (2017). In ARNRB site, shrinkages apparently occurred when winds turned from north-northwest to north, with predominance from the biogenic emissions sector (Sorribas et al., 2015). Possibly, the aerosol that reached the site under these conditions corresponded to biogenic secondary organic aerosol that was gradually losing its volatile fraction during the transport. Nevertheless, the possible drivers for the only case identified in ACN-UB have not been determined. The ER found in this study ranged between 11.4 and $-2.2 \mathrm{~nm}^{\mathrm{h}}{ }^{-1}$, in the range of other values reported in the bibliography (Alonso-Blanco et al., 2017). The shrinkage phase of P-S type had a longer duration than the rest of the S-types identified in this study $3.4 \pm 1.4 \mathrm{~h}$ vs $1.6 \pm 0.8 \mathrm{~h}$ in average respectively (Table S7). Clear examples representative of each type of shrinkage events observed in both sites can be seen in Fig. 8 and S8. Although, shrinkage processes have not been observed in MSY-RB during these field campaigns, they have been documented at this site (Cusack et al., 2013a). 


\section{Conclusions}

Two field campaigns (warm and cold periods) at seven representative sites in the framework of the REDMAAS network have allowed to assess the variability of the PNSDs in response to local and regional emission sources, meteorology and dynamical processes, for the first time in Spain.

Local and regional sources together with meteorological factors control the particle number concentration and their size distribution at each site, showing a considerable diurnal and weekly dynamic pattern. Clear differences have been found between the so-called "polluted" and "clean" sites. Seasonal variations were of major importance on the concentration of ultrafine particles at polluted sites. The highest $N_{t o t}$ values were found in the cold period. Diurnal and weekly variations were also very marked, particularly in the Aitken mode size range. $N_{\text {tot }}$ on WKs were higher than during WEs. Important differences in local meteorology, particularly wind circulation, were found between both measurement periods, and were especially pronounced at ACN-UB site. Here, a coastal site, land-sea breezes influenced ultrafine particle concentration during the warm period, with a similar behaviour as the clean sites. Thus, except for ACN-UB, average modal peaks observed at urban background sites can be recognized as Aitken-mode particles attributed to traffic emissions for polluted sites.

For clean sites seasonal effects were less marked than for polluted ones. Although in these sites the highest particles number concentrations were expected to be observed in the warm period, similar diurnal and weekly variations were found in both periods. This finding was attributed to particles nucleated in the atmosphere or from the coastal and regional industrial emissions in coastal sites. Thus, PNSDs varied slightly, showing a first modal peak as nucleation-mode particles and a second modal peak as Aitken or accumulation-mode particles (background aerosol).

Differences in the characteristics of ultrafine particles were found between inlandcoastal sites. $N_{\text {tot }}$ at coastal sites were higher than at the inland sites in the warm period and the opposite in the cold period. Also, the smallest $D_{\text {mode }}$ and the highest 
variations of PNSDs in the smaller particles size were observed in coastal sites, especially in the warm period. This was likely a result of the typical atmospheric circulation (sea-land breezes) in these areas with great diffusion conditions and strong mixture of clean and polluted air masses, being the impact of the coastal and regional emissions on ultrafine particles very important at these sites.

These results were derived in part from aerosol dynamical processes identified during the campaigns. Thus, atmospheric nucleation episodes occurred in clean sites during both periods, while in polluted sites they were only identified in CIEMAT-UB according to the available data. NPFs were registered around noon when photochemistry was more intense and, with the exception of ARN-RB, under low aerosol concentrations and presumably a high load of aerosol-forming precursors (mainly biogenic). However, and in contrast to the rest of sites, some well-defined NPF episodes occurred under aerosol background conditions in the ARN-RB site. Given that CS remained relatively constant and high before, during, and after these episodes, abundant precursor gases contained in this background appeared to be responsible for aerosol formation. Considering both periods, the highest number of NPFs was found at IZAÑA-HA.

Also, shrinkages processes have been observed during the warm REDMAAS campaign. In CIEMAT-UB and ARN-RB these processes were frequent (6 and 14 cases respectively), while in ACN-UB only one case was observed. All S-types were identified in CIEMAT-UB, NPF+S and P-S types in ARN-RB and P-S type in ACNUB. Their phenomenology was associated with changes in the photochemical activity and wind speed during the day. The causes of ACN-UB shrinkages have not been identified.

Results from this study provide useful information in understanding the role of aerosol sources and meteorology on the aerosol number size distribution across Spain. Thus, studies such as this can help a better understanding the aerosol role and implications on heath and atmospheric processes. In addition, spatio-temporal aerosol size distribution observations like the ones presented in this article can be an important input for the actual aerosol models and can be used in model evaluations. 


\section{Acknowledgements}

This work has been financed by the Ministry of Science and Innovation (CGL20101777, CGL2010-11095-E, CGL2011-27020, CGL2011-15008-E, CGL2012-39623-C02-01, CGL2014-52877-R， CGL2014-55230-R， PI15/00515 (cofounded by the ISCIII Directorate General for Evaluation and the European Regional Development Fund) and CGL2017-85344-R), Xunta de Galicia (GRC2013-047), the Generalitat de Catalunya (AGAUR 2015 SGR33 and SGR33 and the DGQA) and the European Union Seventh Framework Programme (FP7/2007-2013) ACTRIS under grant agreement no. 262254 and ACTRIS-ESPAÑ (CGL2017-90884-REDT) funded by AEI/FEDER, UE. 


\section{References}

Alonso-Blanco, E., Gómez-Moreno, F., Núñez, L., Pujadas, M., Cusack, M., Artíñano, B., 2017. Aerosol particle shrinkage event phenomenology in a South European suburban area during 2009-2015. Atmospheric Environment 160, 154-164.

Artíñano, B., Salvador, P., Alonso, D.G., Querol, X., Alastuey, A., 2003. Anthropogenic and natural influence on the PM 10 and PM 2.5 aerosol in Madrid (Spain). Analysis of high concentration episodes. Environmental pollution 125, 453-465.

Asmi, A., 2012. Weakness of the weekend effect in aerosol number concentrations. Atmospheric environment 51, 100-107.

Asmi, A., Wiedensohler, A., Laj, P., Fjaeraa, A.-M., Sellegri, K., Birmili, W., Weingartner, E., Baltensperger, U., Zdimal, V., Zikova, N., 2011. Number size distributions and seasonality of submicron particles in Europe 2008-2009. Atmospheric Chemistry and Physics 11, 55055538 .

Asmi, E., Kondratyev, V., Brus, D., Laurila, T., Lihavainen, H., Backman, J., Vakkari, V., Aurela, M., Hatakka, J., Viisanen, Y., 2016. Aerosol size distribution seasonal characteristics measured in Tiksi, Russian Arctic. Atmospheric Chemistry and Physics 16, 1271-1287.

Babu, S.S., Kompalli, S.K., Moorthy, K.K., 2016. Aerosol number size distributions over a coastal semi urban location: Seasonal changes and ultrafine particle bursts. Science of The Total Environment 563, 351-365.

Beddows, D., Dall'Osto, M., Harrison, R.M., Kulmala, M., Asmi, A., Wiedensohler, A., Laj, P., Fjæraa, A.M., Sellegri, K., Birmili, W., 2014. Variations in tropospheric submicron particle size distributions across the European continent 2008-2009. Atmospheric Chemistry and Physics 14, 4327-4348.

Bianchi, F., Tröstl, J., Junninen, H., Frege, C., Henne, S., Hoyle, C., Molteni, U., Herrmann, E., Adamov, A., Bukowiecki, N., 2016. New particle formation in the free troposphere: A question of chemistry and timing. Science 352, 1109-1112.

Birmili, W., Weinhold, K., Nordmann, S., Wiedensohler, A., Spindler, G., Müller, K., Herrmann, H., Gnauk, T., Pitz, M., Cyrys, J., 2009. Atmospheric aerosol measurements in the German ultrafine aerosol network (GUAN). Gefahrstoffe Reinhaltung der Luft, 137-145.

Cusack, M., Alastuey, A., Querol, X., 2013a. Case studies of new particle formation and evaporation processes in the western Mediterranean regional background. Atmospheric environment 81, 651-659.

Cusack, M., Pérez, N., Pey, J., Wiedensohler, A., Alastuey, A., Querol, X., 2013b. Variability of sub-micrometer particle number size distributions and concentrations in the Western Mediterranean regional background. Tellus B 65.

Dal Maso, M., Kulmala, M., Lehtinen, K.E., Mäkelä, J., Aalto, P., O'Dowd, C., 2002. Condensation and coagulation sinks and formation of nucleation mode particles in coastal and boreal forest boundary layers. Journal of Geophysical Research: Atmospheres 107.

Dal Maso, M., Kulmala, M., Riipinen, I., Wagner, R., Hussein, T., Aalto, P.P., Lehtinen, K.E., 2005. Formation and growth of fresh atmospheric aerosols: eight years of aerosol size distribution data from SMEAR II, Hyytiala, Finland. Boreal Environment Research 10, 323336. 
Dzepina, K., Mazzoleni, C., Fialho, P., China, S., Zhang, B., Owen, R., Helmig, D., Hueber, J., Kumar, S., Perlinger, J., 2015. Molecular characterization of free tropospheric aerosol collected at the Pico Mountain Observatory: a case study with a long-range transported biomass burning plume. Atmospheric Chemistry and Physics 15, 5047-5068.

Engler, C., Lihavainen, H., Komppula, M., KERMINEN, V.M., Kulmala, M., Viisanen, Y., 2007. Continuous measurements of aerosol properties at the Baltic Sea. Tellus B 59, 728-741.

Fernández-Camacho, R., Rodríguez, S., Rosa, J.1., Sánchez de La Campa, A., Viana, M., Alastuey, A., Querol, X., 2010. Ultrafine particle formation in the inland sea breeze airflow in Southwest Europe. Atmospheric Chemistry and Physics 10, 9615-9630.

García, M.I., Rodríguez, S., Alastuey, A., 2017a. Impact of North America on the aerosol composition in the North Atlantic free troposphere. Atmospheric Chemistry and Physics 17, 7387.

García, M.I., Rodríguez, S., González, Y., García, R.D., 2014. Climatology of new particle formation at Izaña mountain GAW observatory in the subtropical North Atlantic. Atmospheric Chemistry and Physics 14, 3865-3881.

García, M.I., van Drooge, B.L., Rodríguez, S., Alastuey, A., 2017b. Speciation of organic aerosols in the Saharan Air Layer and in the free troposphere westerlies. Atmospheric Chemistry and Physics 17, 8939.

Gómez-Moreno, F., Pujadas, M., Plaza, J., Rodríguez-Maroto, J., Martínez-Lozano, P., Artíñano, B., 2011. Influence of seasonal factors on the atmospheric particle number concentration and size distribution in Madrid. Atmospheric Environment 45, 3169-3180.

Gómez-Moreno, F.J., Alonso, E., Artíñano, B., Juncal-Bello, V., Iglesias-Samitier, S., Piñeiro Iglesias, M., Mahía, P.L., Pérez, N., Pey, J., Ripoll, A., 2015. Intercomparisons of Mobility Size Spectrometers and Condensation Particle Counters in the Frame of the Spanish Atmospheric Observational Aerosol Network. Aerosol Science and Technology 49, 777-785.

Guo, H., Wang, D., Cheung, K., Ling, Z., Chan, C.K., Yao, X., 2012. Observation of aerosol size distribution and new particle formation at a mountain site in subtropical Hong Kong. Atmospheric chemistry and physics 12, 9923-9939.

Hakola, H., Tarvainen, V., Laurila, T., Hiltunen, V., Hellén, H., Keronen, P., 2003. Seasonal variation of VOC concentrations above a boreal coniferous forest. Atmospheric Environment $37,1623-1634$.

Hamed, A., Korhonen, H., Sihto, S.L., Joutsensaari, J., Järvinen, H., Petäjä, T., Arnold, F., Nieminen, T., Kulmala, M., Smith, J.N., 2011. The role of relative humidity in continental new particle formation. Journal of Geophysical Research: Atmospheres 116.

Heal, M.R., Kumar, P., Harrison, R.M., 2012. Particles, air quality, policy and health. Chemical Society Reviews 41, 6606-6630.

HEI, 2013. HEI review panel on ultrafine particles. Understanding the health effects of ambient ultrafine particles. HEI Perspectives 3, Health Effects Institute, Boston, Massachusetts.

Herrmann, E., Weingartner, E., Henne, S., Vuilleumier, L., Bukowiecki, N., Steinbacher, M., Conen, F., Collaud Coen, M., Hammer, E., Jurányi, Z., 2015. Analysis of long-term aerosol size distribution data from Jungfraujoch with emphasis on free tropospheric conditions, cloud influence, and air mass transport. Journal of Geophysical Research: Atmospheres 120, 94599480 . 
Hyvärinen, A.P., Komppula, M., Engler, C., Kivekäs, N., Kerminen, V.M., Dal Maso, M., Viisanen, Y., Lihavainen, H., 2008. Atmospheric new particle formation at Utö, Baltic Sea 2003-2005. Tellus B 60, 345-352.

Iglesias-Samitier, S., Juncal-Bello, V., Piñeiro-Iglesias, M., López-Mahía, P., MuniateguiLorenzo, S., Prada-Rodríguez, D., 2014. Levels and evolution of atmospheric nanoparticles in a suburban area with Atlantic influence, 2nd Iberian Meeting on Aerosol Science and Technology. PUBLICACIONS UNIVERSITAT ROVIRA I VIRGILI, p. 79.

IPCC, 2013. The physical science basis. Contribution of working group I to the fifth assessment report of the intergovernmental panel on climate change. USA: Cambridge University Press.

Järvinen, E., Virkkula, A., Nieminen, T., Aalto, P., Asmi, E., Lanconelli, C., Busetto, M., Lupi, A., Schioppo, R., Vitale, V., 2013. Seasonal cycle and modal structure of particle number size distribution at Dome C, Antarctica. Atmospheric Chemistry and Physics 13, 7473-7487.

Kanawade, V., Tripathi, S., Bhattu, D., Shamjad, P., 2014. Sub-micron particle number size distributions characteristics at an urban location, Kanpur, in the Indo-Gangetic Plain. Atmospheric Research 147, 121-132.

Kivekäs, N., Sun, J., Zhan, M., Kerminen, V.-M., Hyvärinen, A., Komppula, M., Viisanen, Y., Hong, N., Zhang, Y., Kulmala, M., 2009. Long term particle size distribution measurements at Mount Waliguan, a high-altitude site in inland China. Atmospheric Chemistry and Physics 9, 5461-5474.

Koppen, W., 1918. Klassification der Klimet nach Temperatur, Niederschlag und Jahreslauf. Peter-mann's Mitteilungen 64, 193-203,243-248.

Kulmala, M., Maso, M., Mäkelä, J., Pirjola, L., Väkevä, M., Aalto, P., Miikkulainen, P., Hämeri, K., O'dowd, C., 2001. On the formation, growth and composition of nucleation mode particles. Tellus B 53, 479-490.

Kulmala, M., Petäjä, T., Kerminen, V.-M., Kujansuu, J., Ruuskanen, T., Ding, A., Nie, W., $\mathrm{Hu}, \mathrm{M}$., Wang, Z., Wu, Z., 2016. On secondary new particle formation in China. Frontiers of Environmental Science \& Engineering 10, 8.

Kulmala, M., Petäjä, T., Mönkkönen, P., Koponen, I., Maso, M.D., Aalto, P., Lehtinen, K., Kerminen, V.-M., 2005. On the growth of nucleation mode particles: source rates of condensable vapor in polluted and clean environments. Atmospheric Chemistry and Physics 5, 409-416.

Kulmala, M., Petäjä, T., Nieminen, T., Sipilä, M., Manninen, H.E., Lehtipalo, K., Dal Maso, M., Aalto, P.P., Junninen, H., Paasonen, P., 2012. Measurement of the nucleation of atmospheric aerosol particles. Nature protocols 7, 1651-1667.

Larssen, S., Sluyter, R., Helmis, C., 1999. Criteria for EOROAIRNET: The EEA Air Quality Monitoring and Information Network. European Environment Agency.

Lihavainen, H., Alghamdi, M., Hyvärinen, A.-P., Hussein, T., Aaltonen, V., Abdelmaksoud, A., Al-Jeelani, H., Almazroui, M., Almehmadi, F., Al Zawad, F., 2016. Aerosols physical properties at Hada Al Sham, western Saudi Arabia. Atmospheric Environment 135, 109-117.

Liu, B.Y., Pui, D.Y., 1974. A submicron aerosol standard and the primary, absolute calibration of the condensation nuclei counter. Journal of Colloid and Interface Science 47, 155-171. 
Lyamani, H., Olmo Reyes, F.J., Alados-Arboledas, L., 2010. Physical and optical properties of aerosols over an urban location in Spain: seasonal and diurnal variability.

Ma, N., Birmili, W., 2015. Estimating the contribution of photochemical particle formation to ultrafine particle number averages in an urban atmosphere. Science of the Total Environment 512, 154-166.

Masiol, M., Squizzato, S., Chalupa, D.C., Utell, M.J., Rich, D.Q., Hopke, P.K., 2018. Longterm trends in submicron particle concentrations in a metropolitan area of the northeastern United States. Science of The Total Environment 633, 59-70.

Mikkonen, S., Romakkaniemi, S., Smith, J., Korhonen, H., Petäjä, T., Plass-Duelmer, C., Boy, M., McMurry, P., Lehtinen, K., Joutsensaari, J., 2011. A statistical proxy for sulphuric acid concentration. Atmospheric Chemistry and Physics 11, 11319-11334.

Peng, J., Hu, M., Wang, Z., Huang, X., Kumar, P., Wu, Z., Guo, S., Yue, D., Shang, D., Zheng, Z., 2014. Submicron aerosols at thirteen diversified sites in China: size distribution, new particle formation and corresponding contribution to cloud condensation nuclei production. Atmospheric Chemistry and Physics 14, 10249-10265.

Peng, Y., Liu, X., Dai, J., Wang, Z., Dong, Z., Dong, Y., Chen, C., Li, X., Zhao, N., Fan, C., 2017. Aerosol size distribution and new particle formation events in the suburb of Xi'an, northwest China. Atmospheric Environment 153, 194-205.

Piazzola, J., Sellegri, K., Bourcier, L., Mallet, M., Tedeschi, G., Missamou, T., 2012. Physicochemical characteristics of aerosols measured in the spring time in the Mediterranean coastal zone. Atmospheric environment 54, 545-556.

Pirjola, L., Kulmala, M., Wilck, M., Bischoff, A., Stratmann, F., Otto, E., 1999. Formation of sulphuric acid aerosols and cloud condensation nuclei: an expression for significant nucleation and model comprarison. Journal of Aerosol Science 30, 1079-1094.

Plaza, J., Artinano, B., 1994. Characterization of pollutants cycles evolution in a coastal mediterranean area under summer conditions. Centro de Investigaciones Energeticas Medioambientales y Tecnologicas (CIEMAT).

Riipinen, I., Sihto, S.-L., Kulmala, M., Arnold, F., Maso, M.D., Birmili, W., Saarnio, K., Teinilä, K., Kerminen, V.-M., Laaksonen, A., 2007. Connections between atmospheric sulphuric acid and new particle formation during QUEST III-IV campaigns in Heidelberg and Hyytiälä. Atmospheric Chemistry and Physics 7, 1899-1914.

Ripoll, A., Pey, J., Minguillón, M.C., Pérez, N., Pandolfi, M., Querol, X., Alastuey, A., 2014. Three years of aerosol mass, black carbon and particle number concentrations at Montsec (southern Pyrenees, 1570 m asl). Atmospheric Chemistry and Physics 14, 4279-4295.

Robinson, A.L., Donahue, N.M., Shrivastava, M.K., Weitkamp, E.A., Sage, A.M., Grieshop, A.P., Lane, T.E., Pierce, J.R., Pandis, S.N., 2007. Rethinking organic aerosols: Semivolatile emissions and photochemical aging. Science 315, 1259-1262.

Rodríguez, S., Cuevas, E., Prospero, J., Alastuey, A., Querol, X., López-Solano, J., García, M., Alonso-Pérez, S., 2015. Modulation of Saharan dust export by the North African dipole. Atmospheric Chemistry and Physics 15, 7471-7486.

Rodríguez, S., González, Y., Cuevas, E., Ramos, R., Romero, P., Abreu-Afonso, J., Redondas, A., 2009. Atmospheric nanoparticle observations in the low free troposphere during upward orographic flows at Izaña Mountain Observatory. Atmospheric Chemistry and Physics 9, 6319-6335. 
Rodríguez, S., Van Dingenen, R., Putaud, J.-P., Dell'Acqua, A., Pey, J., Querol, X., Alastuey, A., Chenery, S., Ho, K.-F., Harrison, R., 2007. A study on the relationship between mass concentrations, chemistry and number size distribution of urban fine aerosols in Milan, Barcelona and London. Atmospheric Chemistry and Physics 7, 2217-2232.

Rodríguez, S., Van Dingenen, R., Putaud, J.-P., Martins-Dos Santos, S., Roselli, D., 2005. Nucleation and growth of new particles in the rural atmosphere of Northern Italyrelationship to air quality monitoring. Atmospheric environment 39, 6734-6746.

Rose, C., Sellegri, K., Velarde, F., Moreno, I., Ramonet, M., Weinhold, K., Krejci, R., Ginot, P., Andrade, M., Wiedensohler, A., 2015. Frequent nucleation events at the high altitude station of Chacaltaya (5240 m asl), Bolivia. Atmospheric Environment 102, 18-29.

Rosenfeld, D., Lohmann, U., Raga, G.B., O'Dowd, C.D., Kulmala, M., Fuzzi, S., Reissell, A., Andreae, M.O., 2008. Flood or drought: how do aerosols affect precipitation? science 321, 1309-1313.

Rückerl, R., Schneider, A., Breitner, S., Cyrys, J., Peters, A., 2011. Health effects of particulate air pollution: a review of epidemiological evidence. Inhalation toxicology 23, 555592.

Schwarz, J., Cusack, M., Karban, J., Chalupníčková, E., Havránek, V., Smolík, J., Ždímal, V., 2016. PM 2.5 chemical composition at a rural background site in Central Europe, including correlation and air mass back trajectory analysis. Atmospheric Research 176, 108-120.

Seinfeld, J.H., Pandis, S.N., 2016. Atmospheric chemistry and physics: from air pollution to climate change. John Wiley \& Sons.

Shen, X., Sun, J., Zhang, Y., Wehner, B., Nowak, A., Tuch, T., Zhang, X., Wang, T., Zhou, H., Zhang, X., 2011. First long-term study of particle number size distributions and new particle formation events of regional aerosol in the North China Plain. Atmospheric Chemistry and Physics 11, 1565-1580.

Sioutas, C., Delfino, R.J., Singh, M., 2005. Exposure assessment for atmospheric ultrafine particles (UFPs) and implications in epidemiologic research. Environmental health perspectives, 947-955.

Sorribas, M., Adame, J., Andrews, E., Yela, M., 2017. An anomalous African dust event and its impact on aerosol radiative forcing on the Southwest Atlantic coast of Europe in February 2016. Science of The Total Environment 583, 269-279.

Sorribas, M., Adame, J., Olmo, F., Vilaplana, J., Gil-Ojeda, M., Alados-Arboledas, L., 2015. A long-term study of new particle formation in a coastal environment: meteorology, gas phase and solar radiation implications. Science of the Total Environment 511, 723-737.

Sorribas, M., De La Morena, B., Wehner, B., López, J., Prats, N., Mogo, S., Wiedensohler, A., Cachorro, V., 2011. On the sub-micron aerosol size distribution in a coastal-rural site at El Arenosillo Station (SW-Spain). Atmospheric Chemistry and Physics 11, 11185-11206.

Titos, G., Del Águila, A., Cazorla, A., Lyamani, H., Casquero-Vera, J., Colombi, C., Cuccia, E., Gianelle, V., Močnik, G., Alastuey, A., 2017. Spatial and temporal variability of carbonaceous aerosols: Assessing the impact of biomass burning in the urban environment. Science of the Total Environment 578, 613-625.

Tobías, A., Rivas, I., Reche, C., Alastuey, A., Rodríguez, S., Fernández-Camacho, R., de la Campa, A.M.S., de la Rosa, J., Sunyer, J., Querol, X., 2018. Short-term effects of ultrafine 
particles on daily mortality by primary vehicle exhaust versus secondary origin in three Spanish cities. Environment international 111, 144-151.

Tröstl, J., Chuang, W.K., Gordon, H., Heinritzi, M., Yan, C., Molteni, U., Ahlm, L., Frege, C., Bianchi, F., Wagner, R., 2016. The role of low-volatility organic compounds in initial particle growth in the atmosphere. Nature 533, 527-+.

Tsai, H.-H., Yuan, C.-S., Hung, C.-H., Lin, C., Lin, Y.-C., 2011. Influence of sea-land breezes on the tempospatial distribution of atmospheric aerosols over coastal region. Journal of the Air \& Waste Management Association 61, 358-376.

Väkevä, M., Hämeri, K., Puhakka, T., Nilsson, E., Hohti, H., Mäkelä, J., 2000. Effects of meteorological processes on aerosol particle size distribution in an urban background area. Journal of Geophysical Research: Atmospheres 105, 9807-9821.

von Bismarck-Osten, C., Birmili, W., Ketzel, M., Massling, A., Petäjä, T., Weber, S., 2013. Characterization of parameters influencing the spatio-temporal variability of urban particle number size distributions in four European cities. Atmospheric environment 77, 415-429.

Wang, D., Guo, H., Cheung, K., Gan, F., 2014. Observation of nucleation mode particle burst and new particle formation events at an urban site in Hong Kong. Atmospheric environment 99, 196-205.

Wang, Y., Hopke, P.K., Chalupa, D.C., Utell, M.J., 2011. Long-term study of urban ultrafine particles and other pollutants. Atmospheric Environment 45, 7672-7680.

Wang, Y., Hopke, P.K., Utell, M.J., 2012. Urban-scale seasonal and spatial variability of ultrafine particle number concentrations. Water, Air, \& Soil Pollution 223, 2223-2235.

Wehner, B., Wiedensohler, A., 2003. Long term measurements of submicrometer urban aerosols: statistical analysis for correlations with meteorological conditions and trace gases. Atmospheric Chemistry and Physics 3, 867-879.

Wiedensohler, A., Birmili, W., Nowak, A., Sonntag, A., Weinhold, K., Merkel, M., Wehner, B., Tuch, T., Pfeifer, S., Fiebig, M., Fjäraa, A.M., Asmi, E., Sellegri, K., Depuy, R., Venzac, H., Villani, P., Laj, P., Aalto, P., Ogren, J.A., Swietlicki, E., Williams, P., Roldin, P., Quincey, P., Hüglin, C., Fierz-Schmidhauser, R., Gysel, M., Weingartner, E., Riccobono, F., Santos, S., Grüning, C., Faloon, K., Beddows, D., Harrison, R., Monahan, C., Jennings, S.G., O’Dowd, C.D., Marinoni, A., Horn, H.-G., Keck, L., Jiang, J., Scheckman, J., McMurry, P.H., Deng, Z., Zhao, C.S., Moerman, M., Henzing, B., de Leeuw, G., Löschau, G., Bastian, S., 2012. Mobility particle size spectrometers: harmonization of technical standards and data structure to facilitate high quality long-term observations of atmospheric particle number size distributions. Atmospheric Measurement Techniques 5, 657-685.

Wiedensohler, A., Wehner, B., Birmili, W., 2002. Aerosol number concentrations and size distributions at mountain-rural, urban-influenced rural, and urban-background sites in Germany. Journal of aerosol medicine 15, 237-243.

Willeke, K., Liu, B.Y., 1976. Single particle optical counter: principle and application, Fine particles. Elsevier, pp. 697-729.

Wu, Z., Hu, M., Lin, P., Liu, S., Wehner, B., Wiedensohler, A., 2008. Particle number size distribution in the urban atmosphere of Beijing, China. Atmospheric Environment 42, 79677980 .

Zhu, Y., Hinds, W.C., Shen, S., Sioutas, C., 2004. Seasonal trends of concentration and size distribution of ultrafine particles near major highways in Los Angeles Special Issue of 
Aerosol Science and Technology on Findings from the Fine Particulate Matter Supersites program. Aerosol Science and Technology 38, 5-13.

Zhu, Y., Sabaliauskas, K., Liu, X., Meng, H., Gao, H., Jeong, C.-H., Evans, G.J., Yao, X., 2014. Comparative analysis of new particle formation events in less and severely polluted urban atmosphere. Atmospheric environment 98, 655-664.

Zíková, N., Ždímal, V., 2013. Long-term measurement of aerosol number size distributions at rural background station Košetice. Aerosol Air Qual. Res 13, 1464-1474. 


\section{Figures}
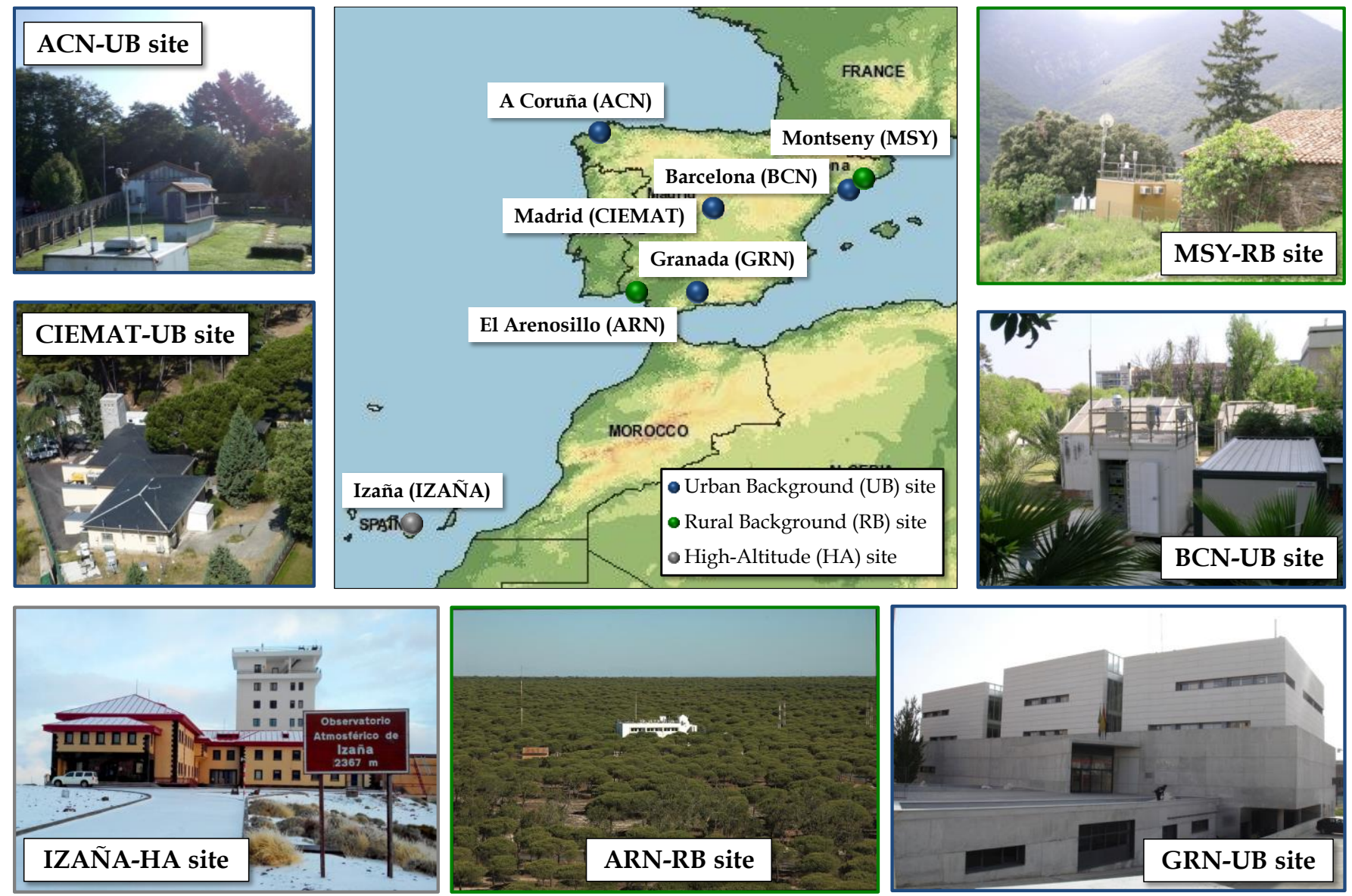

Fig. 1 Approximate distribution of REDMAAS sites within Spain. 


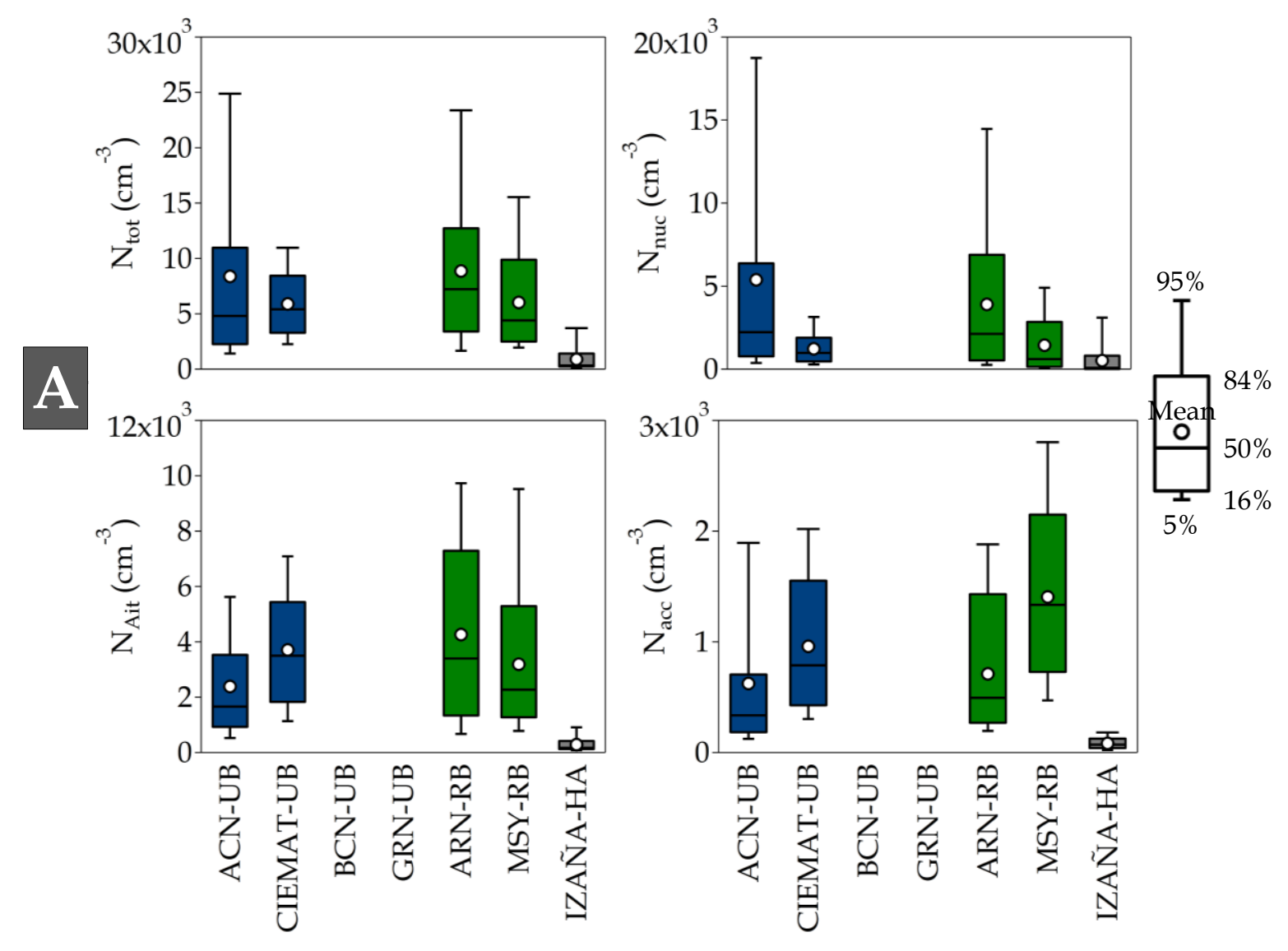



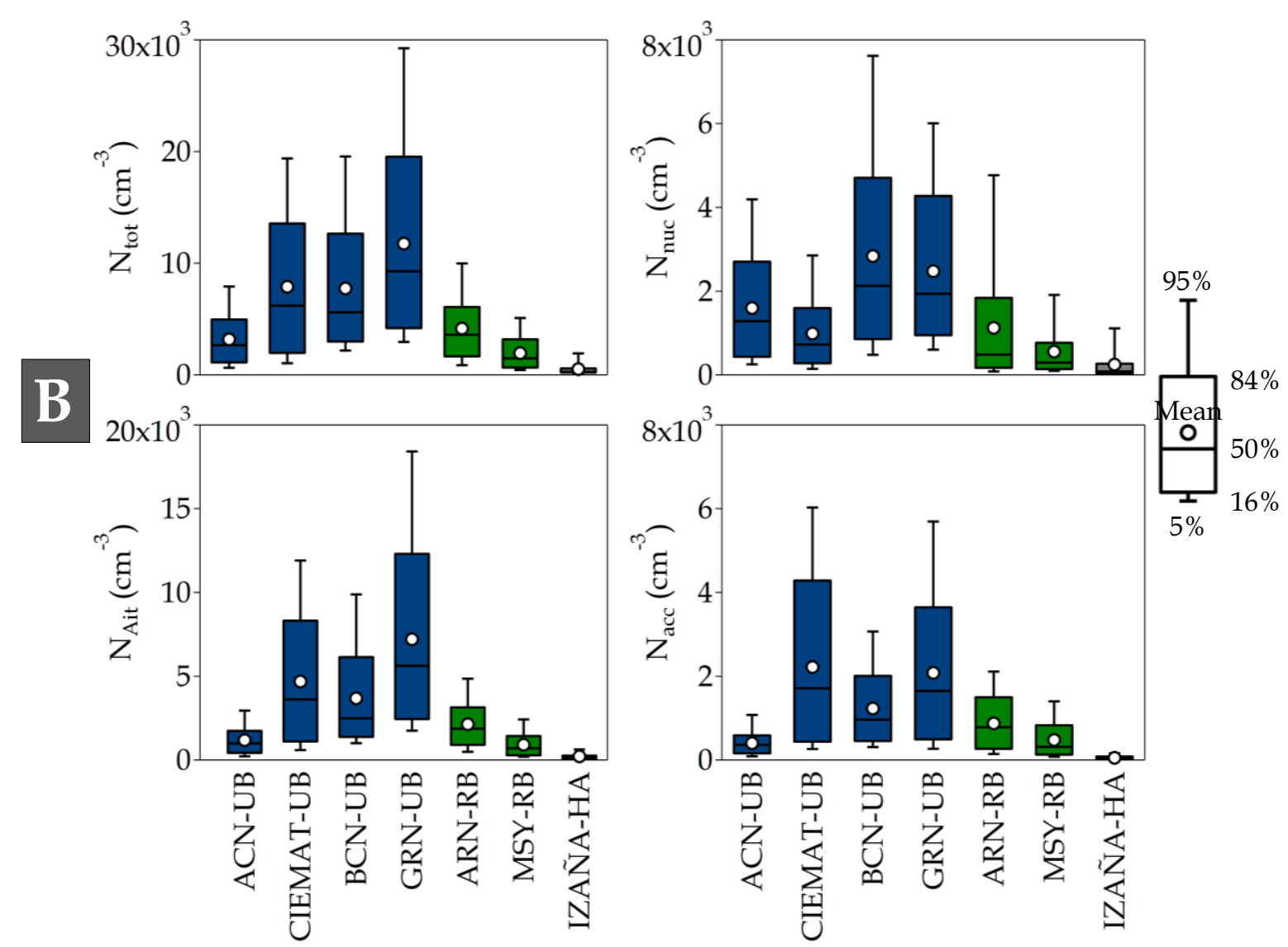

Fig. 2. Boxplots for the observed total $\left(N_{t o t}\right)$ and modal $\left(N_{\text {nuc }}, N_{\text {Ait }}\right.$ and $\left.N_{\text {acc }}\right)$ average particle number concentrations at the seven studied sites during: A) warm REDMAAS field campaign and B) cold REDMAAS field campaign. Box colors indicate the type of site (Blue=urban background, green=rural background, grey=high-altitude). 

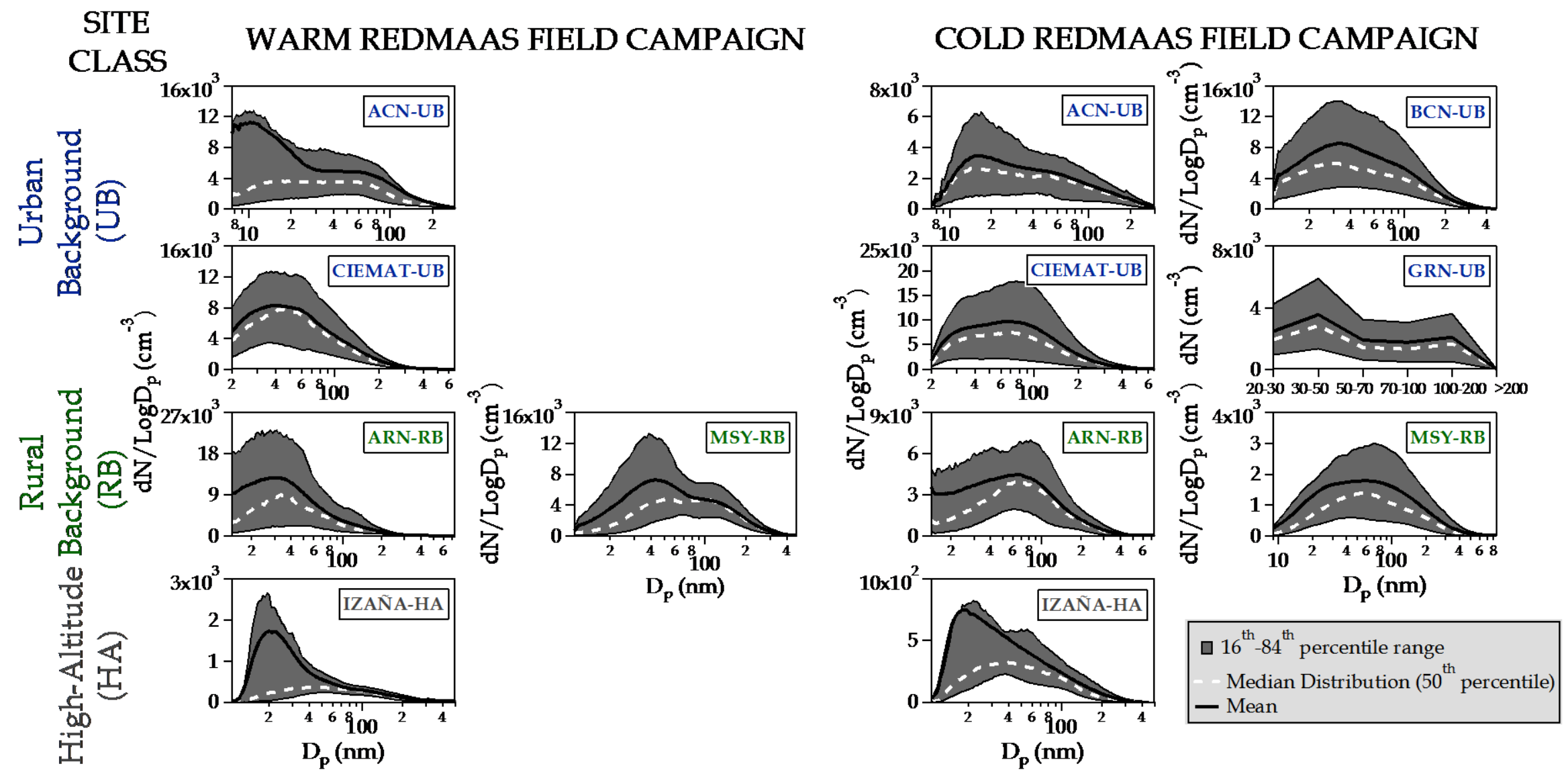

Fig. 3 . The $16^{\text {th }}, 50^{\text {th }}$ (median), $84^{\text {th }}$ percentiles and mean of the particle size distribution at the different sites during the REDMAAS field campaigns calculated from 10-min mean values. 


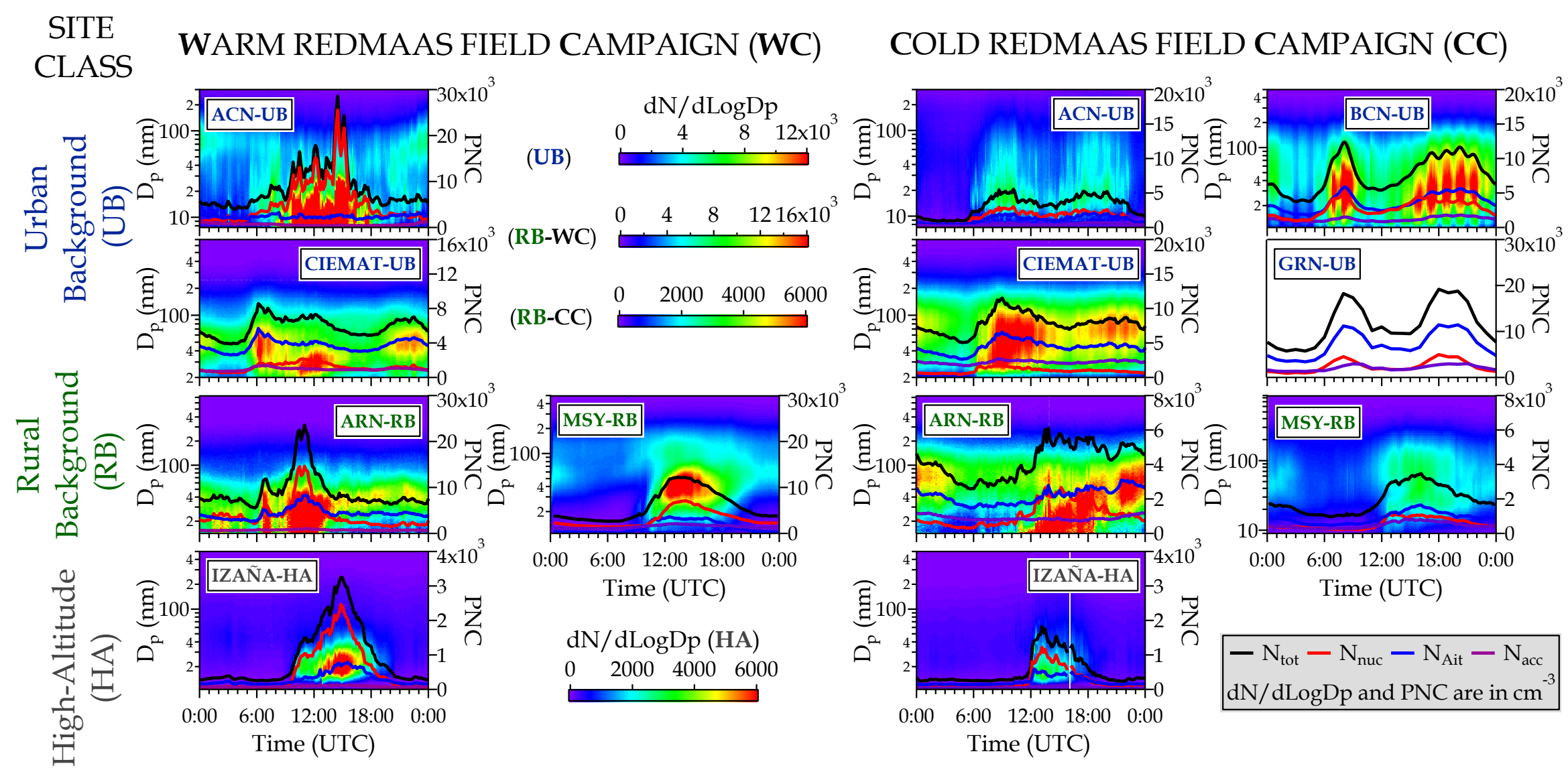

Fig. 4. Particle number size distribution and number concentration, total $\left(N_{t o t}\right)$ and per mode $\left(N_{\text {nuc }}, N_{\text {Ait }}\right.$ and $\left.N_{\text {acc }}\right)$, average daily evolution during the REDMAAS field campaigns calculated from 10-min mean values of the particle size distribution. The aerosol data from BCN-UB site presented in this plot have been slightly smoothed using a ten-point rolling mean. 

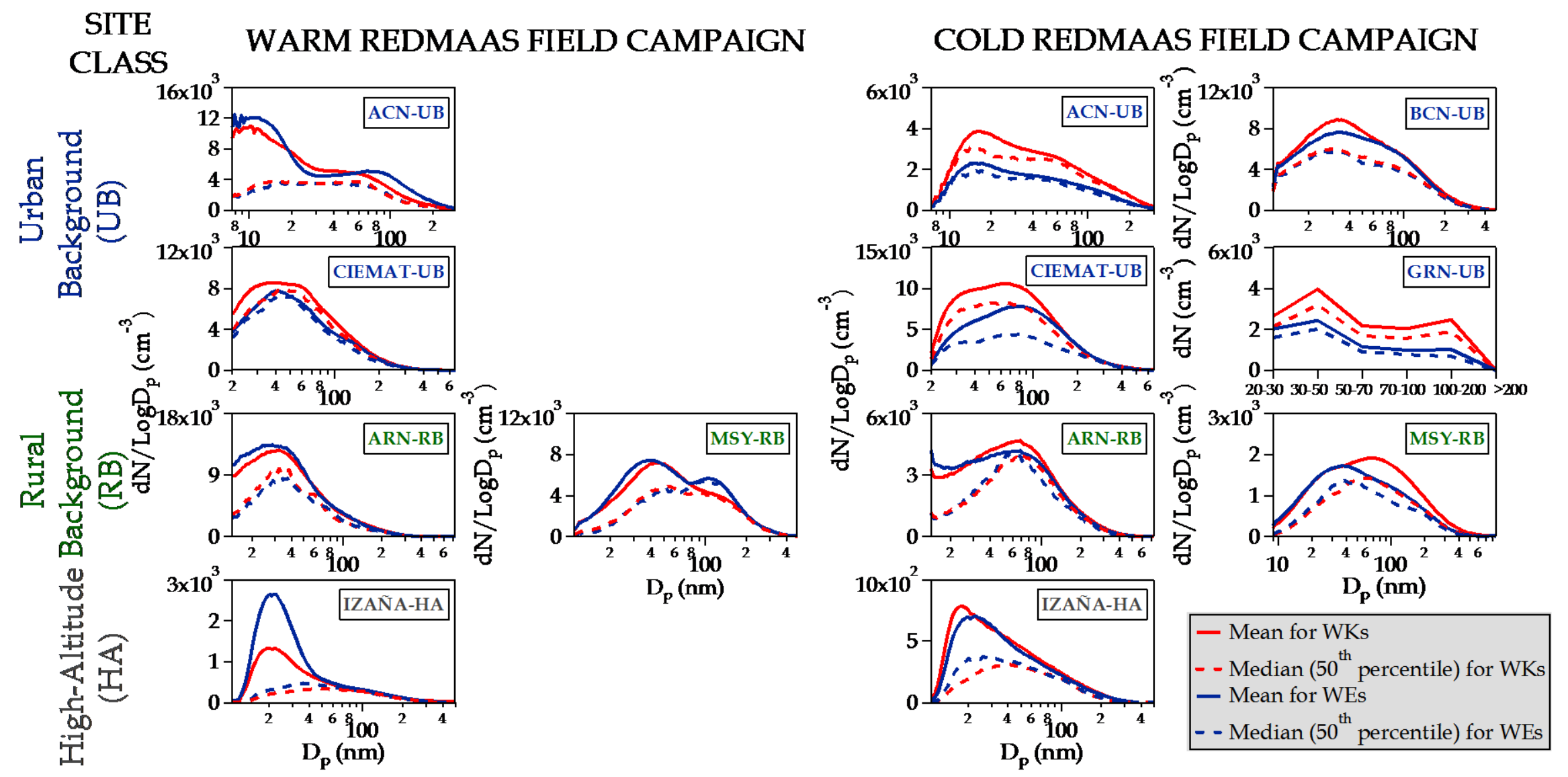

Fig. 5. Mean and median of the particle size distribution for all period, workdays (WKs) and weekends (WEs) of each REDMAAS field campaigns calculated from 10-min mean values. 


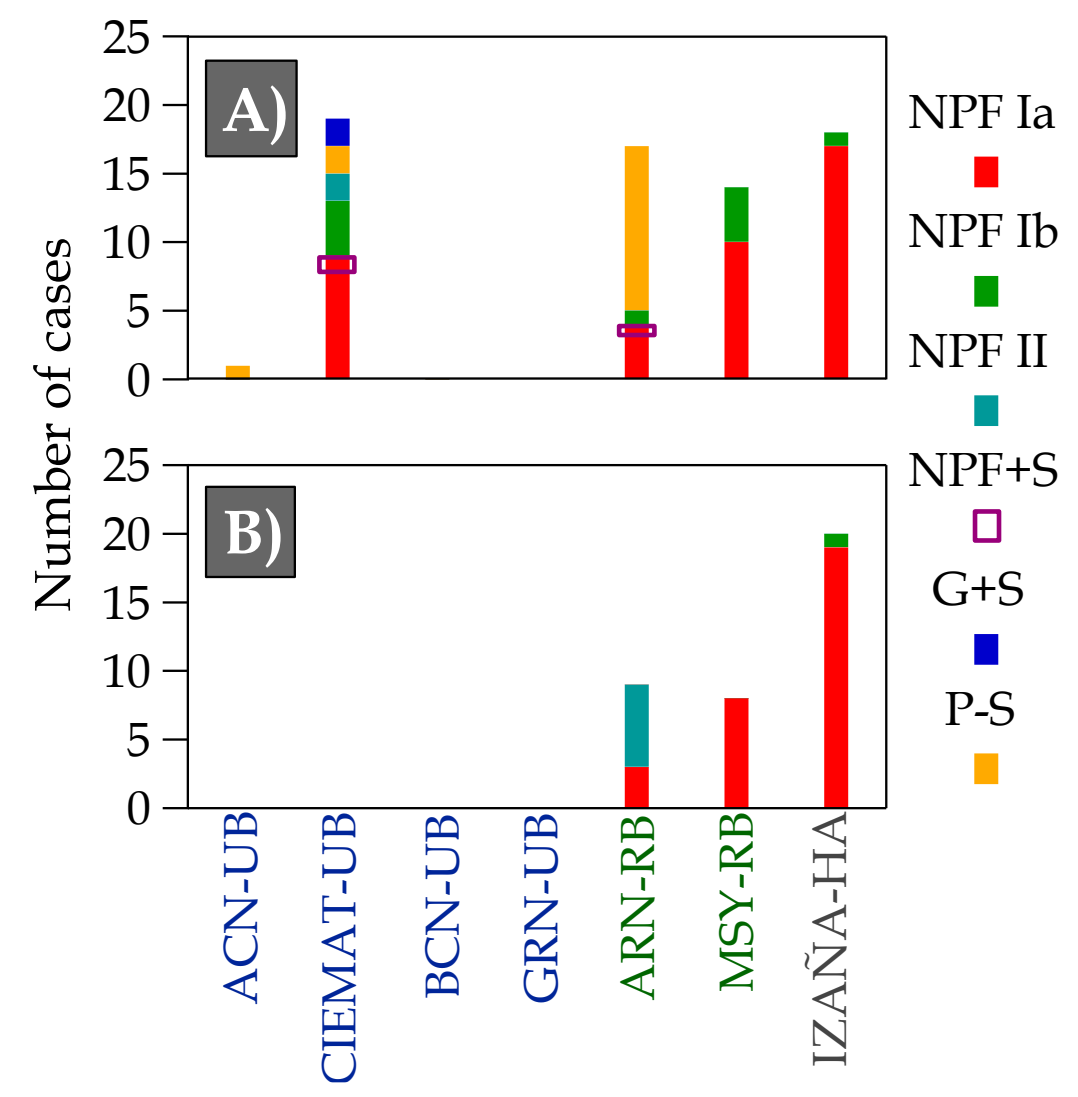

Fig. 6. Number of NPF and aerosol particle shrinkage events observed during: A) warm REDMAAS field campaign and B) cold REDMAAS field campaign. For NPF events, NPF Ia refers to clear and strong NPF events, NPF Ib refers to NPF events with a less pronounced growth than NPF Ia and NPF II refers to NPF events with a growth and formation rate poorly defined. In the case of aerosol particle shrinkage events, NPF+S refers to shrinkage occurs after an NPF, G+S refers to shrinkage occurs after an aerosol growth process and P-S refers to a shrinkage process only. For more detailed information on categorization of NPF and aerosol particle shrinkage events, see Table 1. 
$\mathrm{dN} / \mathrm{dLogDp}\left(\mathrm{cm}^{-3}\right)$

$\mathrm{dN} / \mathrm{d} \log D p\left(\mathrm{~cm}^{-3}\right)$
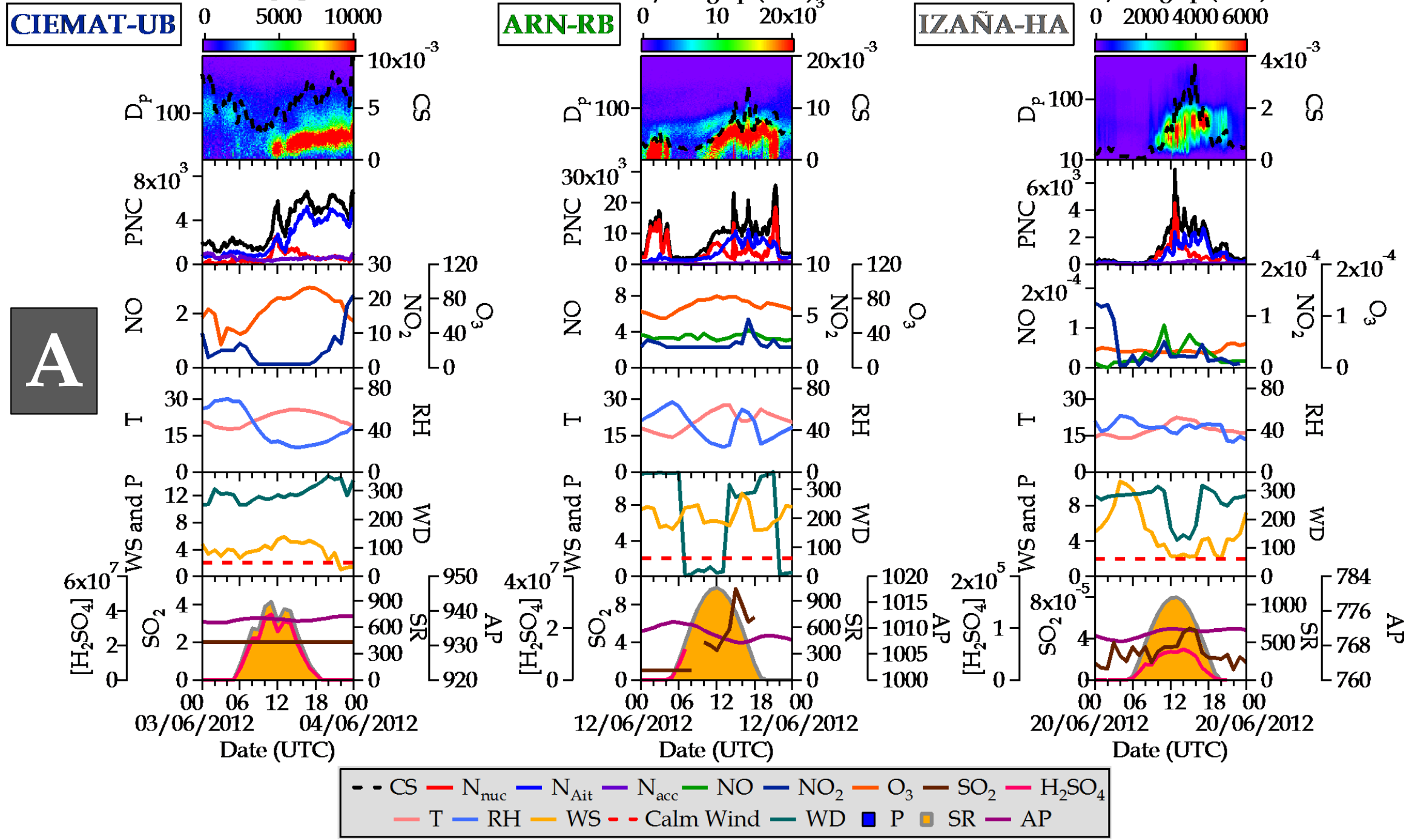

IZAÑA-HA

$\mathrm{dN} / \mathrm{dLogDp}\left(\mathrm{cm}^{-3}\right)$

$0 \quad 200040006000$ 
$\mathrm{dN} / \mathrm{dLogDp}\left(\mathrm{cm}^{-3}\right)$

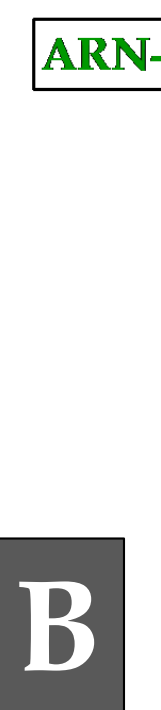

$0 \quad 5000 \quad 10000$

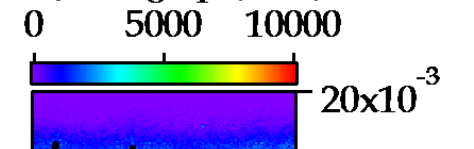

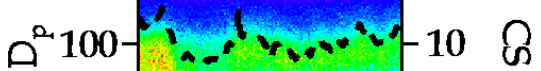
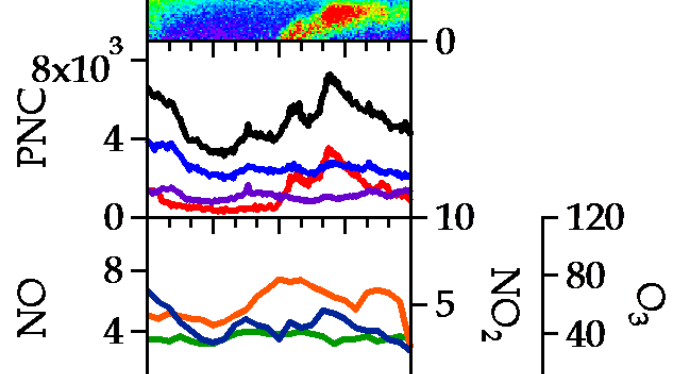

$\mapsto \quad 15$
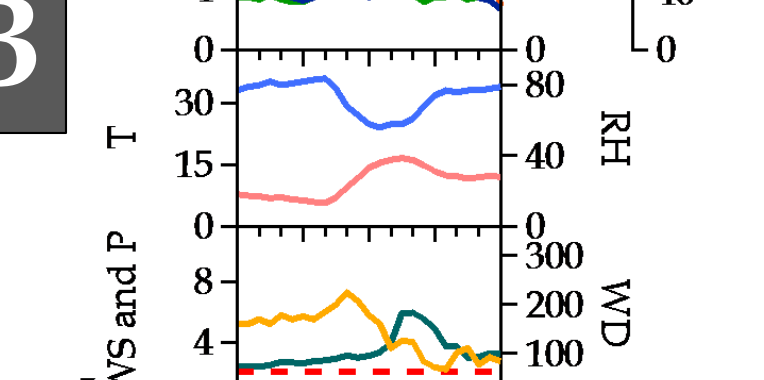

$6 \times 10^{7}$

蛋 $3-$

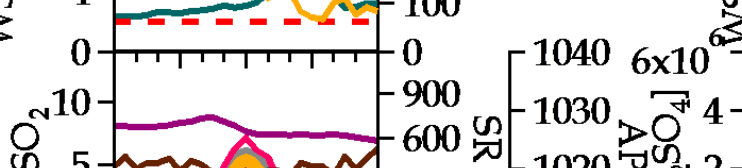

क 5 -rintern- 600

00061218

05/01/2013 06/01/2013

Date (UTC)

ค

Z

1010
$\mathrm{dN} / \mathrm{dLogDp}\left(\mathrm{cm}^{-3}\right)_{3}$
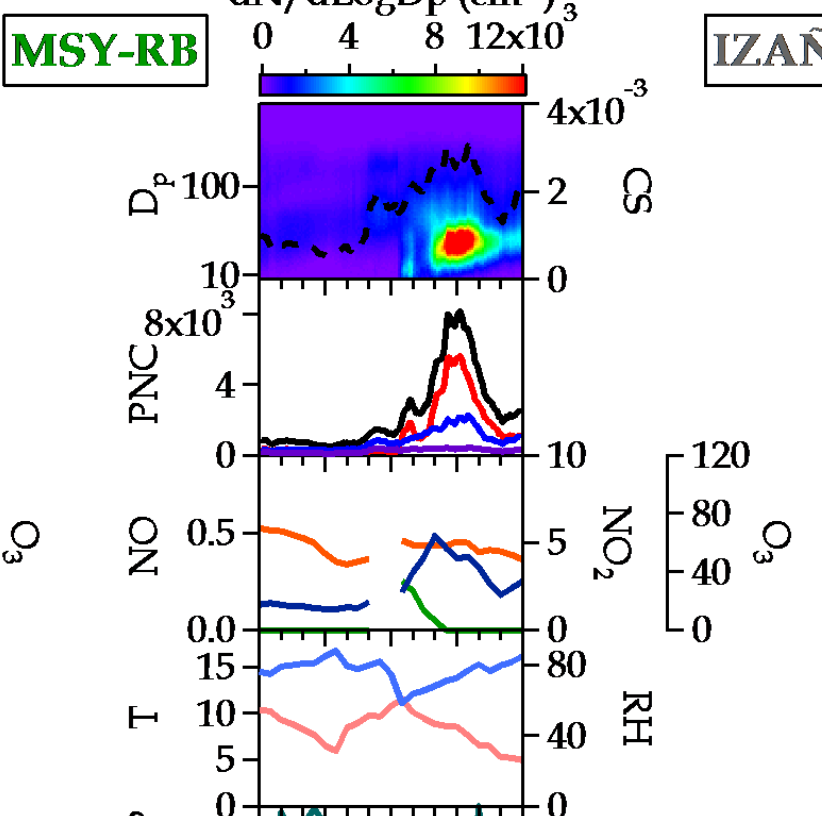

a $\quad 0$ Mir'T-300

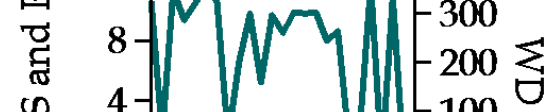

on $4-1,-100$

0 का
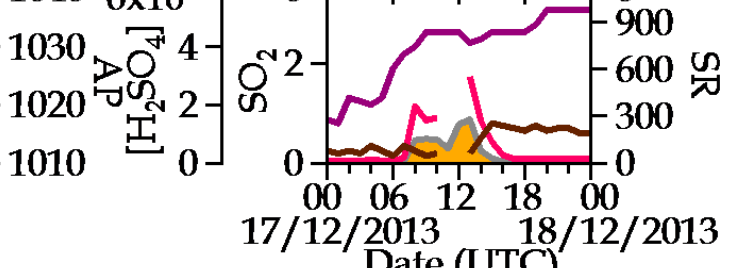

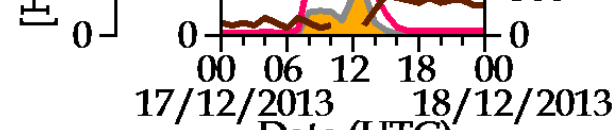
Date (UTC)
$\mathrm{dN} / \mathrm{dLogDp}\left(\mathrm{cm}^{-3}\right)$

IZAÑN-HA $\quad 0 \quad 200040006000$

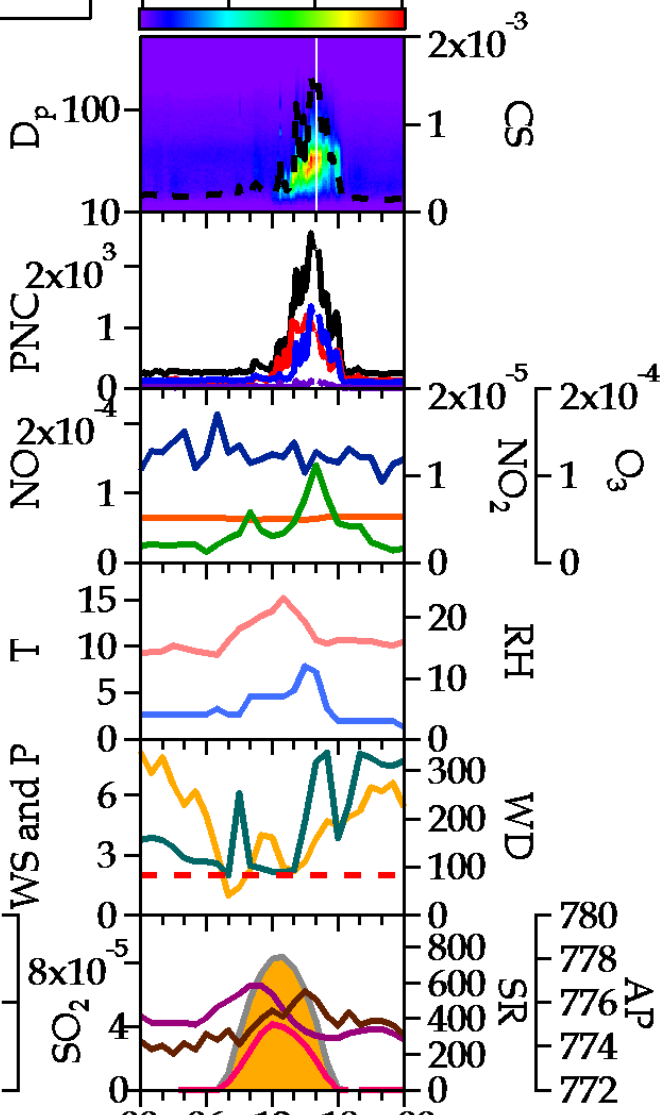

$\begin{array}{lllll}00 & 12 & 18 & 00\end{array}$ $30 / 12 / 2013 \quad 31 / 12 / 2013$ Date (UTC)

$--\mathrm{CS}-\mathrm{N}_{\text {nuc }}-\mathrm{N}_{\mathrm{Ait}}-\mathrm{N}_{\mathrm{acc}}-\mathrm{NO}-\mathrm{NO}_{2}-\mathrm{O}_{3}-\mathrm{SO}_{2}-\mathrm{H}_{2} \mathrm{SO}_{4}$

$-\mathrm{T}-\mathrm{RH}-\mathrm{WS}--$ Calm Wind $-\mathrm{WD} \square \mathrm{P} \square \mathrm{SR}-\mathrm{AP}$ 
Fig. 7. Typical examples of NPF episodes events observed during the (A) warm and (B) cold REDMAAS field campaigns. Parameters (units) are denoted in the graphs as follows: $\mathrm{D}_{\mathrm{p}}=$ particle diameter $(\mathrm{nm}), D_{\text {mode }}=$ modal diameter of the measured particle number size distribution $(\mathrm{nm}), \mathrm{CS}=$ Condensation Sink $\left(\mathrm{s}^{-1}\right), \mathrm{PNC}=$ Particle Number Concentration $\left(\mathrm{cm}^{-3}\right), N_{t o t}=$ Particle Number Total Concentration $\left(\mathrm{cm}^{-3}\right)$, $N_{n u c}=$ Nucleation-mode particles $\left(\mathrm{cm}^{-3}\right), N_{A i t}=$ Aitken-mode particles $\left(\mathrm{cm}^{-3}\right), N_{\text {acc }}=$ Accumulation-mode particles $\left(\mathrm{cm}^{-3}\right), \mathrm{T}=$ Temperature $\left({ }^{\circ} \mathrm{C}\right)$, RH= Relative Humidity (\%), WS=Wind Speed $\left(\mathrm{m} \mathrm{s}^{-1}\right.$, Calm WS $\left.<2 \mathrm{~m} \mathrm{~s}^{-1}\right), \mathrm{WD}=$ Wind Direction (degrees), P=Precipitation (mm) , SR= Solar Radiation $\left(\mathrm{W} \cdot \mathrm{m}^{-2}\right)$ and $\mathrm{AP}=$ Atmospheric Pressure (mbar). Trace gas pollutants $\left(\mathrm{NO}, \mathrm{NO}_{2}, \mathrm{O}_{3}\right.$ and $\mathrm{SO}_{2}$, all in $\left.\mu \mathrm{g} \cdot \mathrm{cm}^{-3}\right)$ and sulfuric acid proxy $\left(\left[\mathrm{H}_{2} \mathrm{SO}_{4}\right]\right.$ in molecules $\left.\cdot \mathrm{cm}^{-3}\right)$ are also presented. 

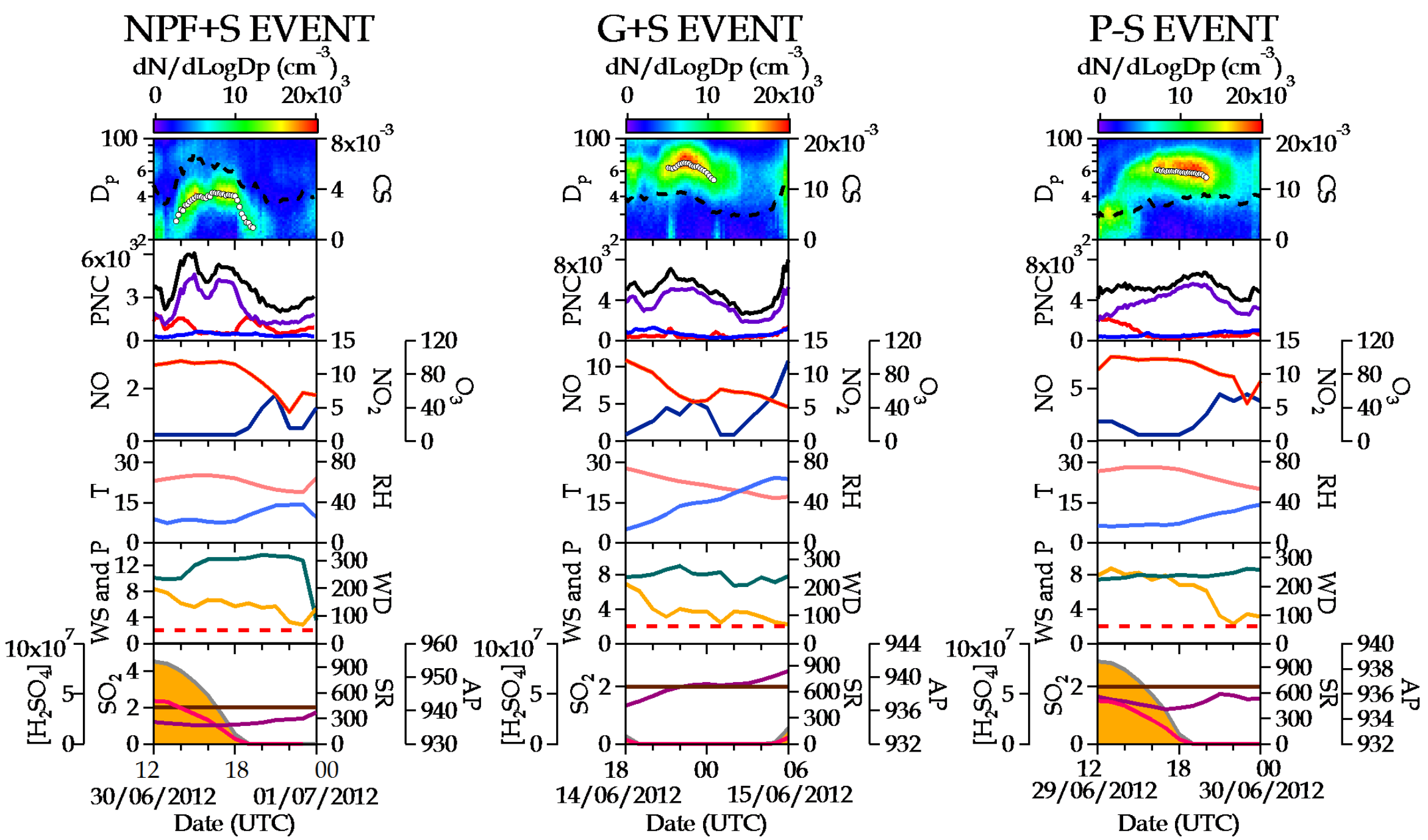

$$
\begin{gathered}
-\mathrm{CS} \circ \mathrm{D}_{\text {mode }}-\mathrm{N}_{\text {tot }}-\mathrm{N}_{\text {nuc }}-\mathrm{N}_{\mathrm{Ait}}-\mathrm{N}_{\mathrm{acc}}-\mathrm{NO}-\mathrm{NO}_{2}-\mathrm{O}_{3}-\mathrm{SO}_{2} \\
-\left[\mathrm{H}_{2} \mathrm{SO}_{4}\right]-\mathrm{T}-\mathrm{RH}-\mathrm{WS}--\mathrm{Calm} \mathrm{Wind}-\mathrm{WD} \square \mathrm{P} \square \mathrm{SR}-\mathrm{AP}
\end{gathered}
$$


Fig. 8. Typical examples for each group of aerosol particle shrinkage events (NPF+S, G+S and P-S) observed at CIEMAT-UB site during the warm REDMAAS field campaign. Parameters (units) are denoted in the graphs as follows: $\mathrm{Dp}=$ particle diameter (nm), $D_{m o d e}=$ modal diameter of the measured particle number size distribution $(\mathrm{nm}), \mathrm{CS}=$ Condensation Sink $\left(\mathrm{s}^{-1}\right)$, PNC=Particle Number Concentration $\left(\mathrm{cm}^{-3}\right)$, $N_{t o t}=$ Particle Number Total Concentration $\left(\mathrm{cm}^{-3}\right), \quad N_{n u c}=$ Nucleation-mode particles $\left(\mathrm{cm}^{-3}\right), \quad N_{A i t}=$ Aitken-mode particles $\left(\mathrm{cm}^{-3}\right)$, $N_{a c c}=$ Accumulation-mode particles $\left(\mathrm{cm}^{-3}\right), \mathrm{T}=$ Temperature $\left({ }^{\circ} \mathrm{C}\right), \mathrm{RH}=$ Relative Humidity $(\%)$, WS=Wind Speed $\left(\mathrm{m} \mathrm{s}^{-1}\right.$, Calm WS $\left.<2 \mathrm{~m} \cdot \mathrm{s}^{-1}\right)$, $\mathrm{WD}=$ Wind Direction (degrees), $\mathrm{P}=$ Precipitation $(\mathrm{mm}), \mathrm{SR}=$ Solar Radiation $\left(\mathrm{W} \cdot \mathrm{m}^{-2}\right)$ and AP=Atmospheric Pressure (mbar). Trace gas pollutants $\left(\mathrm{NO}, \mathrm{NO}_{2}, \mathrm{O}_{3}\right.$ and $\mathrm{SO}_{2}$, all in $\left.\mu \mathrm{g} \cdot \mathrm{cm}^{-3}\right)$ and sulfuric acid proxy $\left(\left[\mathrm{H}_{2} \mathrm{SO}_{4}\right]\right.$ in molecules $\left.\cdot \mathrm{cm}^{-3}\right)$ are also presented. 


\section{Tables}

Table 1. Categorization of NPF and aerosol particle shrinkage events according to methods introduced by Dal Maso et al. (2005) and Alonso-Blanco et al. (2017) respectively.

\begin{tabular}{ccc} 
Type & Description \\
\hline & NPF events \\
\hline
\end{tabular}

I (Ia or Ib)

Events with well defined formation and growth rates of new particles, Ia (clear and strong particle formation events) and $\mathrm{Ib}$ (the rest of events of type I).

Events with poorly defined formation and growth rates of new particles.

$$
\text { Aerosol particles shrinkage events }
$$

$\mathrm{NPF}+$ shrinkage $(\mathrm{NPF}+\mathrm{S})$

Shrinkage processes that occur during the growth phase of the newly nucleated

Aerosol particle growth

Shrinkage processes that occur during an aerosol growth process.

Pure shrinkage (P-S)

Shrinkages in the absence of a previous process. 
Table 2. Parameters $\left(D_{\text {mode }}=\right.$ modal diameter, $\sigma_{\mathrm{g}}=$ modal geometric standard deviation and $\mathrm{N}=$ modal peak concentration $)$ obtained by fitting a multi-lognormal model to the median particle number size distributions for all days, workdays (WKs) and weekend (WEs) during the REDMAAS field campaigns.

\begin{tabular}{|c|c|c|c|c|c|c|c|c|c|c|c|c|c|c|c|c|c|c|c|c|c|}
\hline & \multicolumn{3}{|c|}{ ACN-UB } & \multicolumn{3}{|c|}{ CIEMAT-UB } & \multicolumn{3}{|c|}{ BCN-UB } & \multicolumn{3}{|c|}{ GRN-UB } & \multicolumn{3}{|c|}{ ARN-RB } & \multicolumn{3}{|c|}{ MSY-RB } & \multicolumn{3}{|c|}{ IZAÑA-HA } \\
\hline \multicolumn{22}{|c|}{ Warm REDMAAS field campaign } \\
\hline & All days & WKs & WEs & All days & WKs & WEs & All days & WKs & WEs & All days & WKs & WEs & All days & WKs & WEs & All days & WKs & WEs & All days & WKs & WEs \\
\hline \multicolumn{22}{|l|}{$\begin{array}{l}\text { Fitted } \\
\text { mode } 1\end{array}$} \\
\hline $\begin{array}{l}D_{\text {mode }} \\
(\mathrm{nm})\end{array}$ & 15.0 & 14.1 & 17.6 & 45 & 45.4 & 44.4 & & & & & & & 34.7 & 35.3 & 33.6 & 47.6 & 49.7 & 44.8 & 27.7 & 27.2 & 28.4 \\
\hline$\sigma_{g}$ & 1.8 & 1.8 & 2.0 & 2.0 & 2.0 & 2.0 & & & & & & & 1.9 & 1.9 & 1.9 & 1.8 & 1.8 & 1.6 & 1.5 & 1.5 & 1.5 \\
\hline $\begin{array}{c}\mathrm{N} \\
\left(\mathrm{cm}^{-3}\right)\end{array}$ & 3315 & 3444 & 3289 & 7502 & 7771 & 6918 & & & & & & & 8197 & 7862 & 9105 & 4327 & 4547 & 3968 & 197 & 163 & 300 \\
\hline \multicolumn{22}{|l|}{$\begin{array}{l}\text { Fitted } \\
\text { mode } 2\end{array}$} \\
\hline $\begin{array}{l}D_{\text {mode }} \\
(\mathrm{nm})\end{array}$ & 55.3 & 57.9 & 63.4 & & & & & & & & & & & & & 128.3 & 138.4 & 121.2 & 69.6 & 70 & 68.1 \\
\hline$\sigma_{g}$ & 1.8 & 1.8 & 1.8 & & & & & & & & & & & & & 1.5 & 1.5 & 1.5 & 2.0 & 2.0 & 2.0 \\
\hline $\begin{array}{c}\mathrm{N} \\
\left(\mathrm{cm}^{-3}\right) \\
\end{array}$ & 3286 & 3522 & 2614 & & & & & & & & & & & & & 3243 & 2587 & 4548 & 309 & 307 & 315 \\
\hline \multicolumn{22}{|c|}{ Cold REDMAAS field campaign } \\
\hline & All days & WKs & WEs & All days & WKs & WEs & All days & WKs & WEs & All days & WKs & WEs & All days & WKs & WEs & All days & WKs & WEs & All days & WKs & WEs \\
\hline \multicolumn{22}{|l|}{$\begin{array}{l}\text { Fitted } \\
\text { mode } 1\end{array}$} \\
\hline $\begin{array}{l}D_{\text {mode }} \\
(\mathrm{nm})\end{array}$ & 14.5 & 14 & 13.9 & 31 & 31.3 & 29.3 & 27.6 & 27 & 27.9 & 36.6 & 37 & 34.1 & 63.5 & 64.6 & 59.5 & 51.8 & 58.4 & 42.2 & 24.9 & 26.8 & 21.6 \\
\hline$\sigma_{g}$ & 1.4 & 1.3 & 1.4 & 1.2 & 1.2 & 1.2 & 2.2 & 2.2 & 2.2 & 1.5 & 1.5 & 1.5 & 2.0 & 2.0 & 2.0 & 2.2 & 2.3 & 2.0 & 1.5 & 1.5 & 1.3 \\
\hline
\end{tabular}




\begin{tabular}{|c|c|c|c|c|c|c|c|c|c|c|c|c|c|c|c|c|c|c|c|c|c|}
\hline $\begin{array}{c}\mathrm{N} \\
\left(\mathrm{cm}^{-3}\right)\end{array}$ & 1684 & 1793 & 1141 & 1968 & 2777 & 1102 & 5773 & 5766 & 5651 & 2735 & 3076 & 2008 & 3766 & 3749 & 3721 & 1374 & 1416 & 1341 & 195 & 206 & 227 \\
\hline \multicolumn{22}{|l|}{$\begin{array}{l}\text { Fitted } \\
\text { mode } 2\end{array}$} \\
\hline $\begin{array}{l}D_{\text {mode }} \\
(\mathrm{nm})\end{array}$ & 44.6 & 41.8 & 40.7 & 67.5 & 67.3 & 72.6 & 105.1 & 102.3 & 108.7 & 127.1 & 126.5 & 118.3 & & & & 181.1 & 190.2 & 163.3 & 60 & 66.2 & 50.1 \\
\hline$\sigma_{g}$ & 2.5 & 2.5 & 2.3 & 2.0 & 2.0 & 2.2 & 1.6 & 1.8 & 1.6 & 1.4 & 1.4 & 1.4 & & & & 2.0 & 1.3 & 1.5 & 2.0 & 1.8 & 2.0 \\
\hline $\begin{array}{c}\mathrm{N} \\
\left(\mathrm{cm}^{-3}\right)\end{array}$ & 2170 & 2544 & 1554 & 7367 & 8238 & 4336 & 2511 & 2683 & 2391 & 1704 & 1968 & 771 & & & & 292 & 175 & 459 & 260 & 240 & 305 \\
\hline
\end{tabular}




\section{Supplementary Material}

\section{Figures}
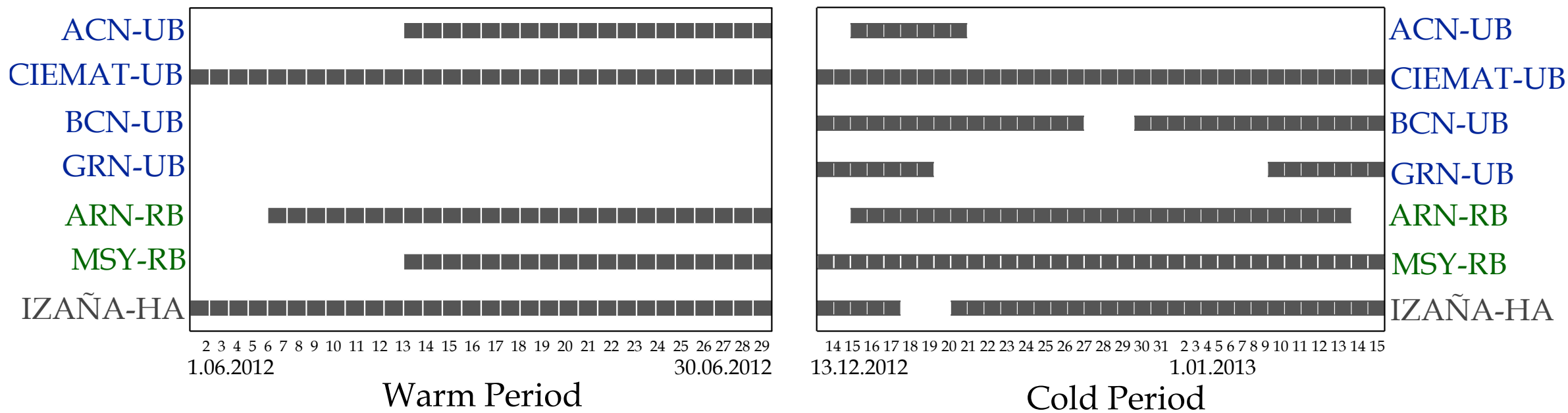

Fig. S1 Data coverage at the different study sites for the REDMAAS field campaigns. 


\section{Urban Background (UB) sites}

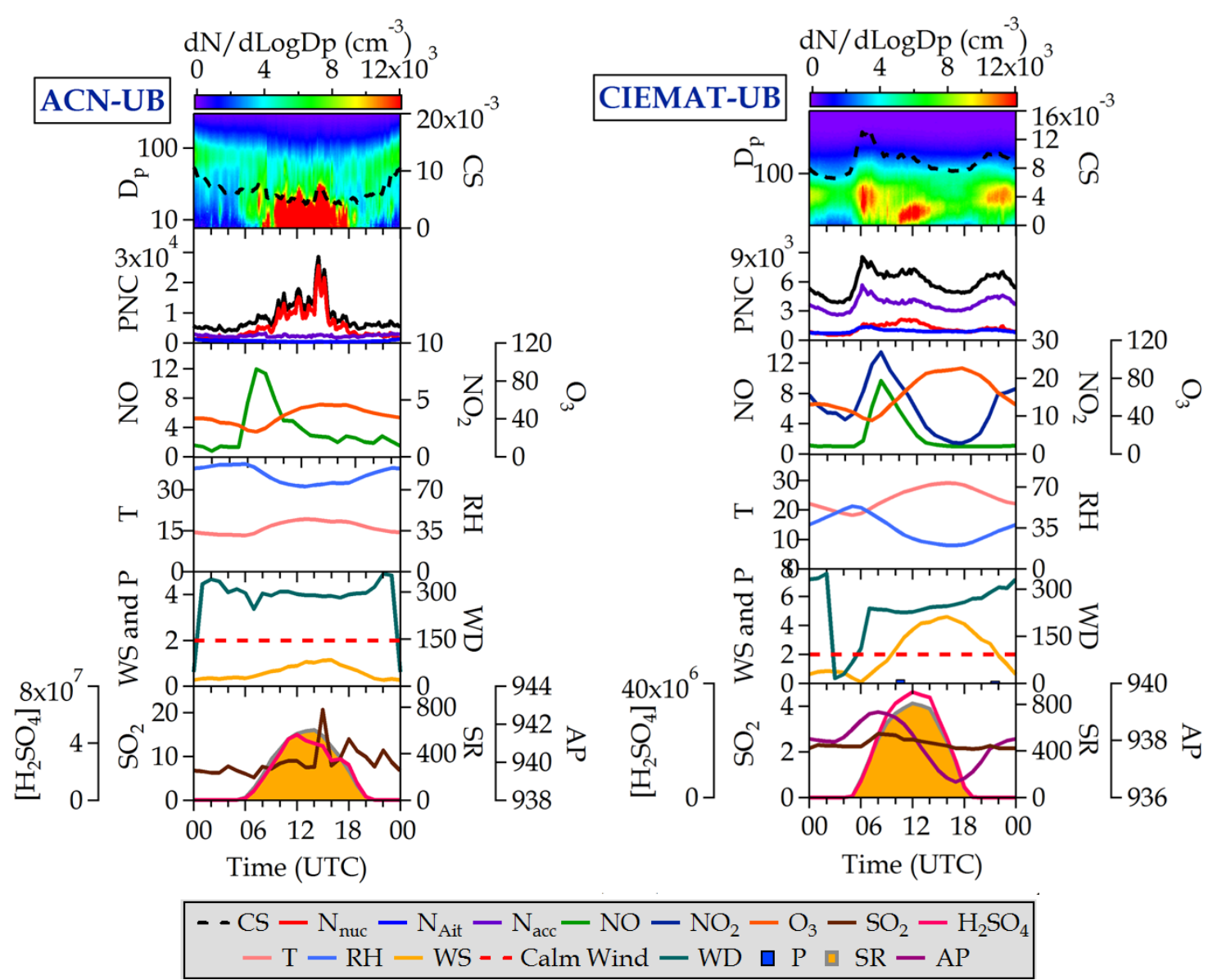




\section{Rural Background (RB) sites}

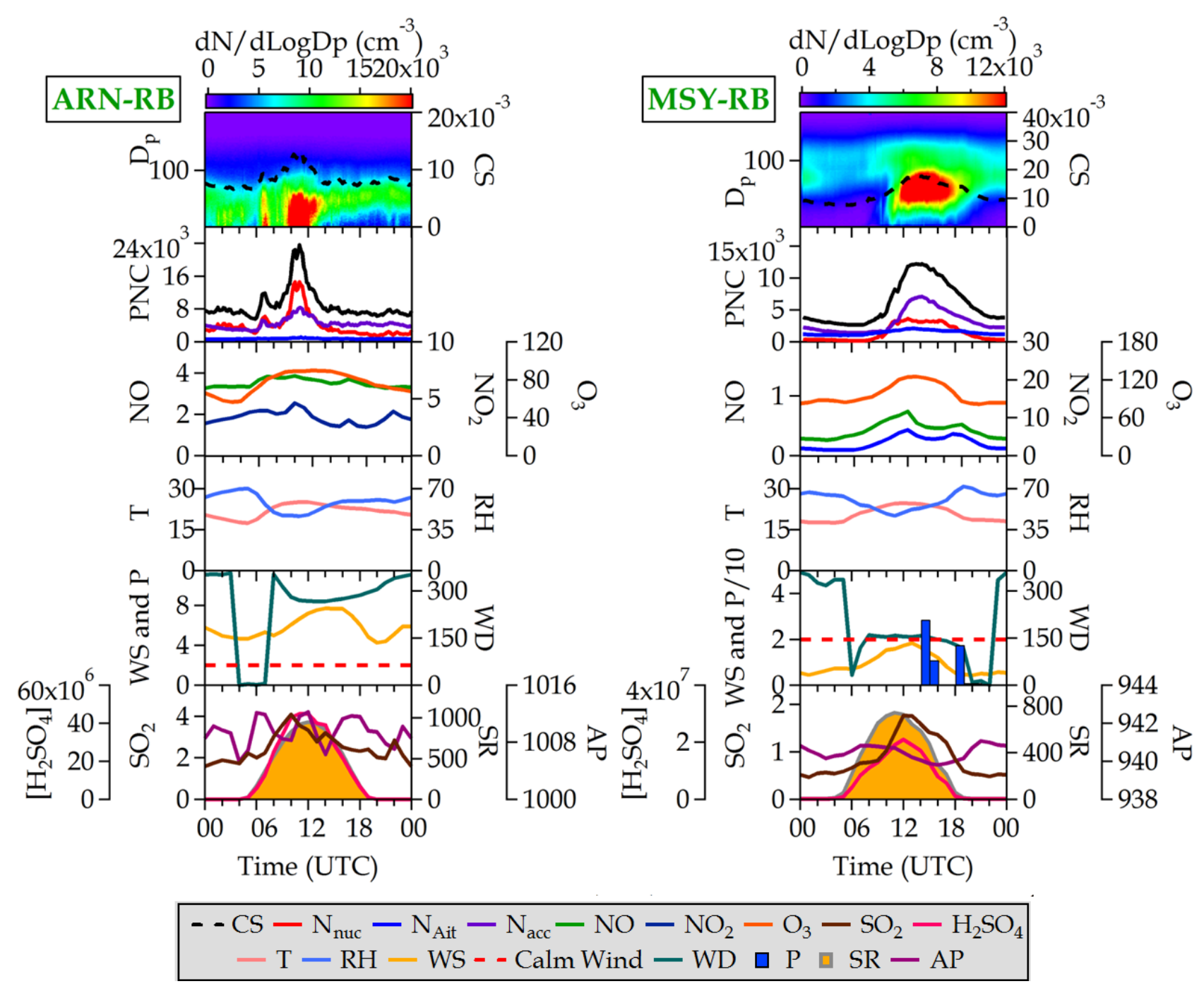


High-Altitude (HA) site

$\mathrm{dN} / \mathrm{dLogDp}\left(\mathrm{cm}^{-3}\right)$

0200040006000

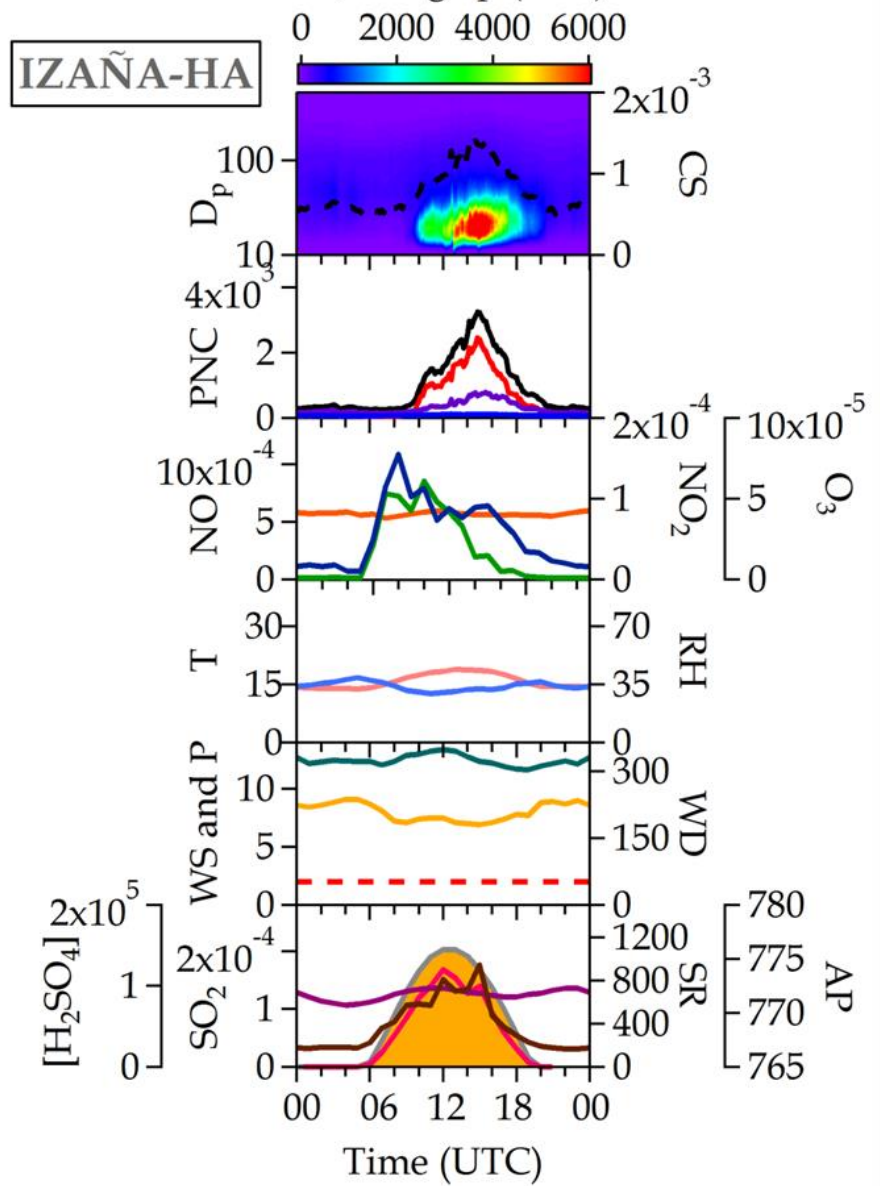

$--\mathrm{CS}-\mathrm{N}_{\text {nuc }}-\mathrm{N}_{\text {Ait }}-\mathrm{N}_{\text {acc }}-\mathrm{NO}-\mathrm{NO}_{2}-\mathrm{O}_{3}-\mathrm{SO}_{2}-\mathrm{H}_{2} \mathrm{SO}_{4}$
$-\mathrm{T}-\mathrm{RH}-\mathrm{WS}--$ Calm Wind $-\mathrm{WD} \square \mathrm{P}$ - SR $-\mathrm{AP}$ 
S2. Daily average of the entire warm REDMAAS field campaign data set for each site (ACN-UB, CIEMAT-UB, ARN-UB, MSYRB and IZAÑA-HA). Here, parameters are denoted as follows: $D_{\mathrm{p}}=$ particle diameter $(\mathrm{nm})$, $C S=$ condensation sink $\left(\mathrm{s}^{-1}\right)$, PNC=Particle Number Concentration $\left(\mathrm{cm}^{-3}\right), N_{t o t}=$ Particle Number Total Concentration $\left(\mathrm{cm}^{-3}\right), N_{n u c}=$ Nucleation-mode particles $\left(\mathrm{cm}^{-3}\right), N_{A i t}=$ Aitken-mode particles $\left(\mathrm{cm}^{-3}\right), N_{a c c}=$ Accumulation-mode particles $\left(\mathrm{cm}^{-3}\right), \mathrm{T}=$ Temperature $\left({ }^{\circ} \mathrm{C}\right)$, HR= Relative Humidity (\%), WS=Wind Speed $\left(\mathrm{m} \mathrm{s}^{-1}\right.$, Calm WS $\left.2 \mathrm{~m} \mathrm{~s}^{-1}\right)$, WD=Wind Direction (degrees), P=Precipitation (mm), SR= Solar Radiation $\left(\mathrm{W} \mathrm{m} \mathrm{m}^{-2}\right)$ and $\mathrm{AP}=$ Atmospheric Pressure (mbar). Trace gas pollutants $\left(\mathrm{NO}, \mathrm{NO}_{2}, \mathrm{O}_{3}\right.$ and $\mathrm{SO}_{2}$ all in $\left.\mu \mathrm{g} \mathrm{m}^{-3}\right)$ and sulfuric acid proxy $\left(\left[\mathrm{H}_{2} \mathrm{SO}_{4}\right]\right.$ in molec $\left.\mathrm{cm}^{-3}\right)$ are also illustrated. 


\section{Urban Background (UB) sites}

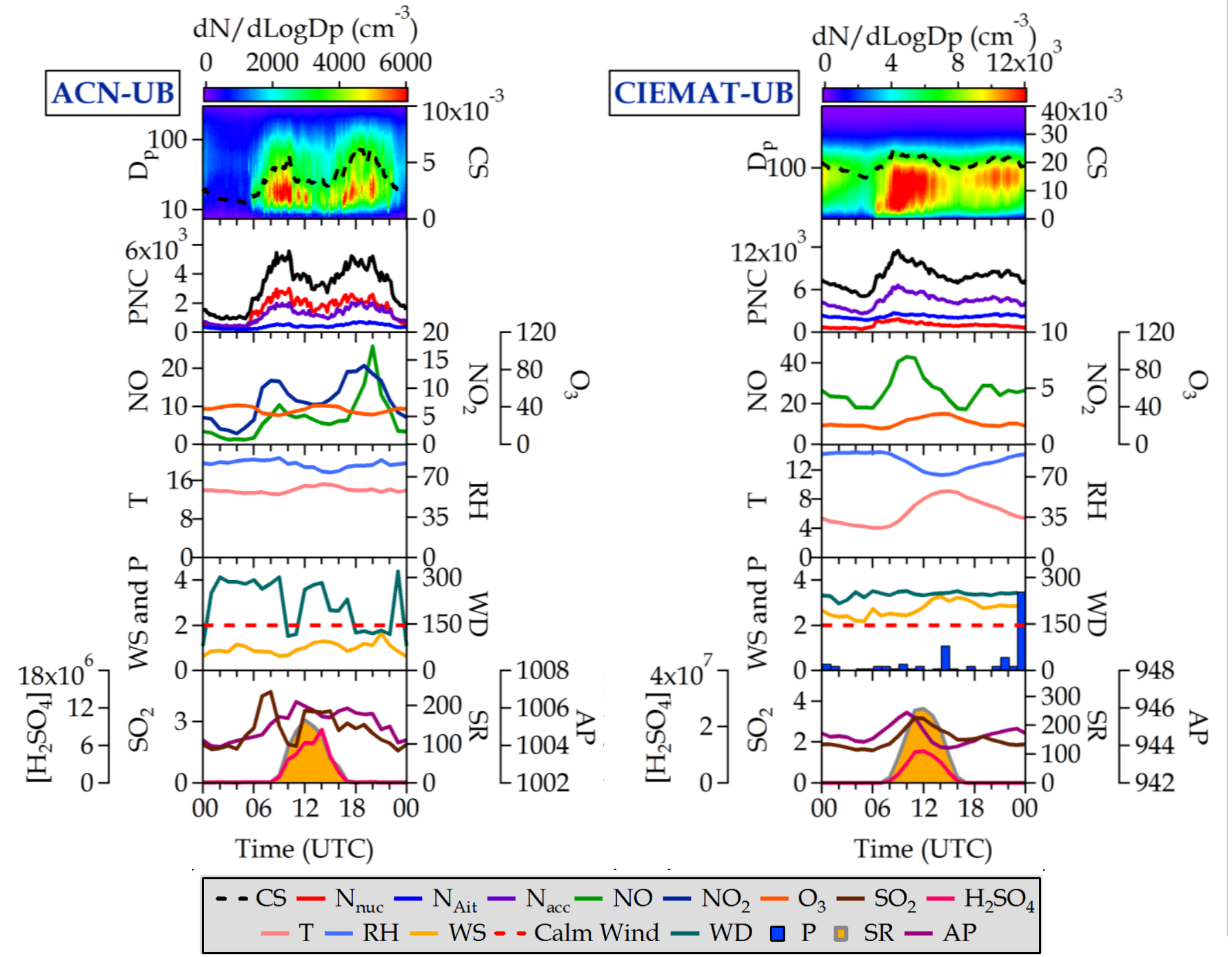




\section{Urban Background (UB) sites}

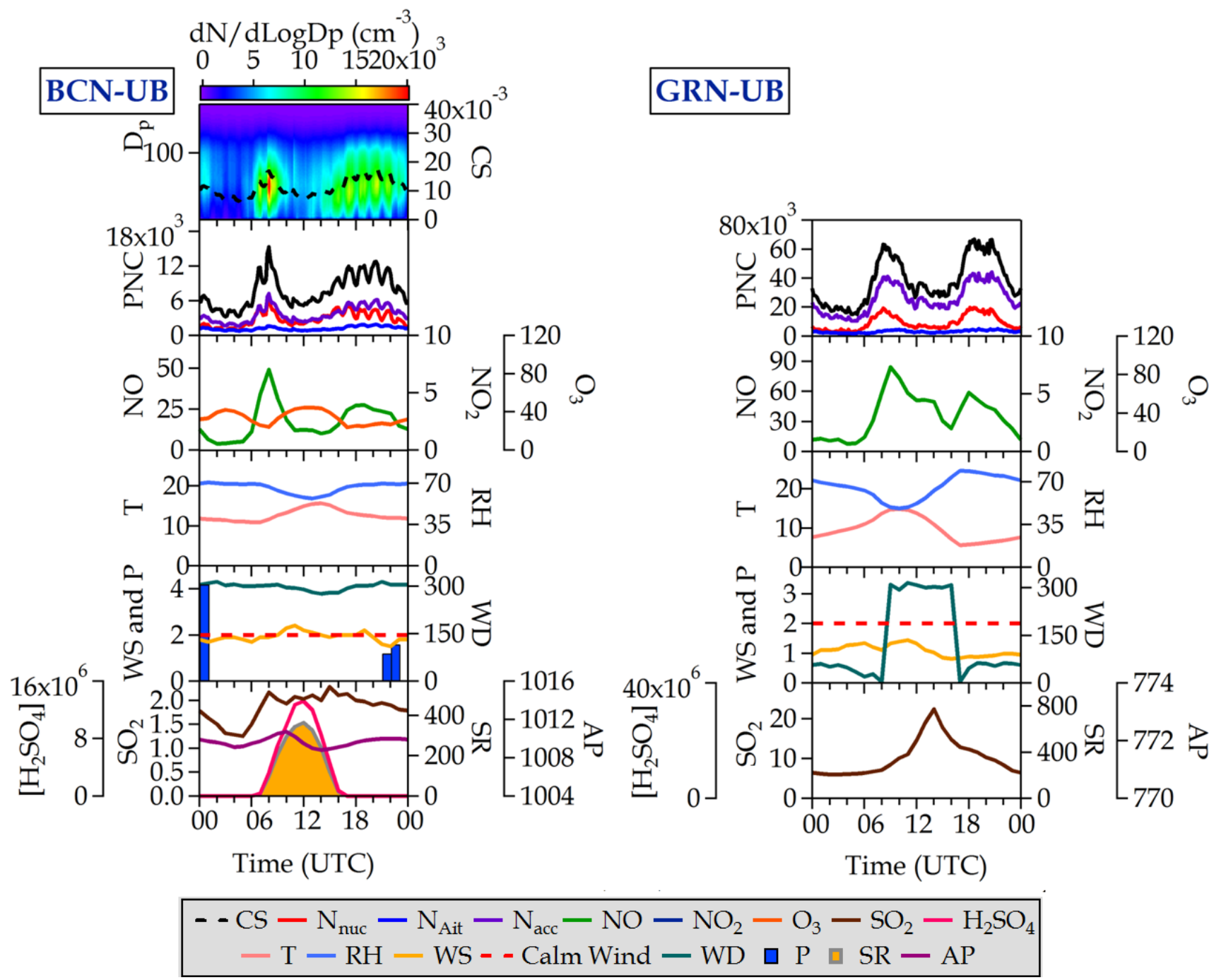


High-Altitude (HA) site $\mathrm{dN} / \mathrm{dLogDp}\left(\mathrm{cm}^{-3}\right)$

$0 \quad 100020003000$

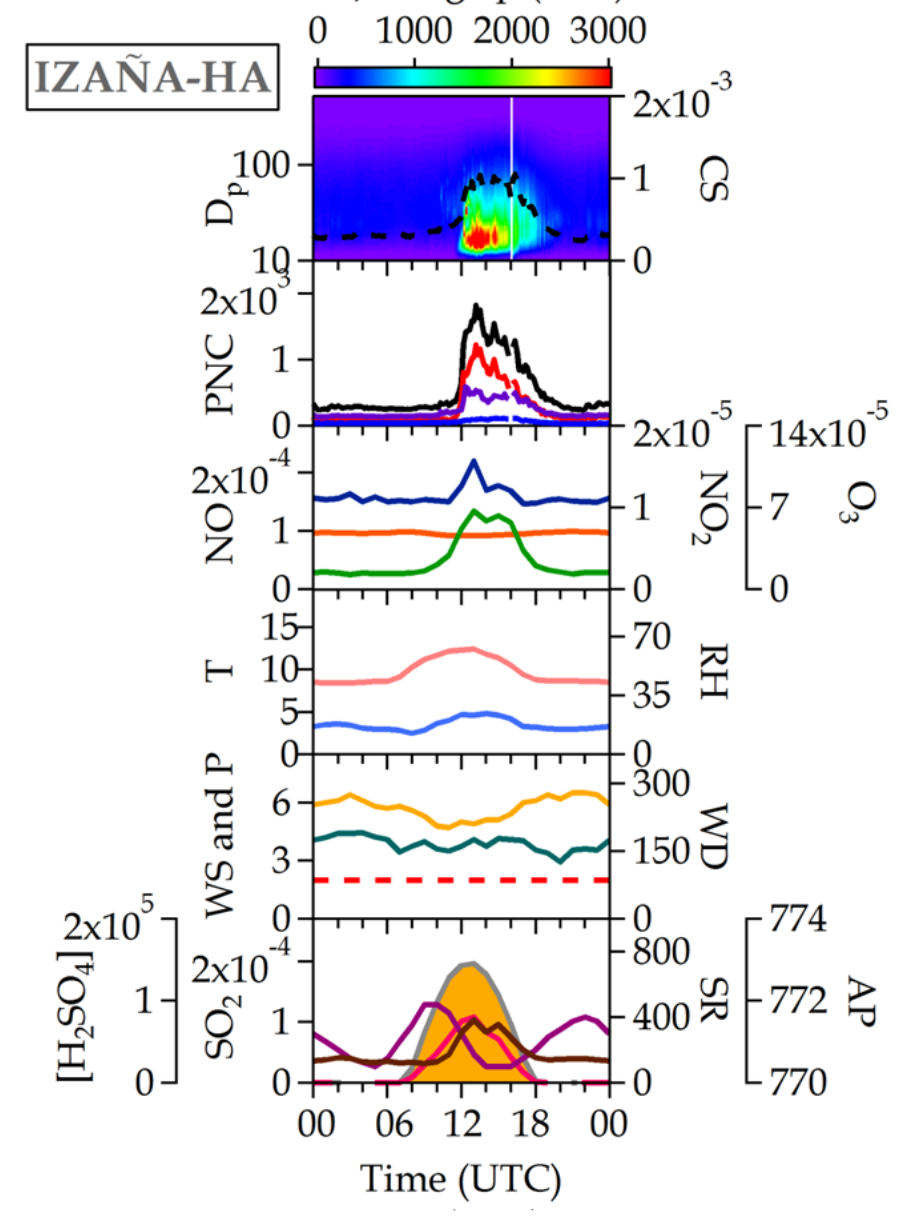

Time (UTC)

$--\mathrm{CS}-\mathrm{N}_{\text {nuc }}-\mathrm{N}_{\mathrm{Ait}}-\mathrm{N}_{\text {acc }}-\mathrm{NO}-\mathrm{NO}_{2}-\mathrm{O}_{3}-\mathrm{SO}_{2}-\mathrm{H}_{2} \mathrm{SO}_{4}$ 


\section{Rural Background (RB) sites}

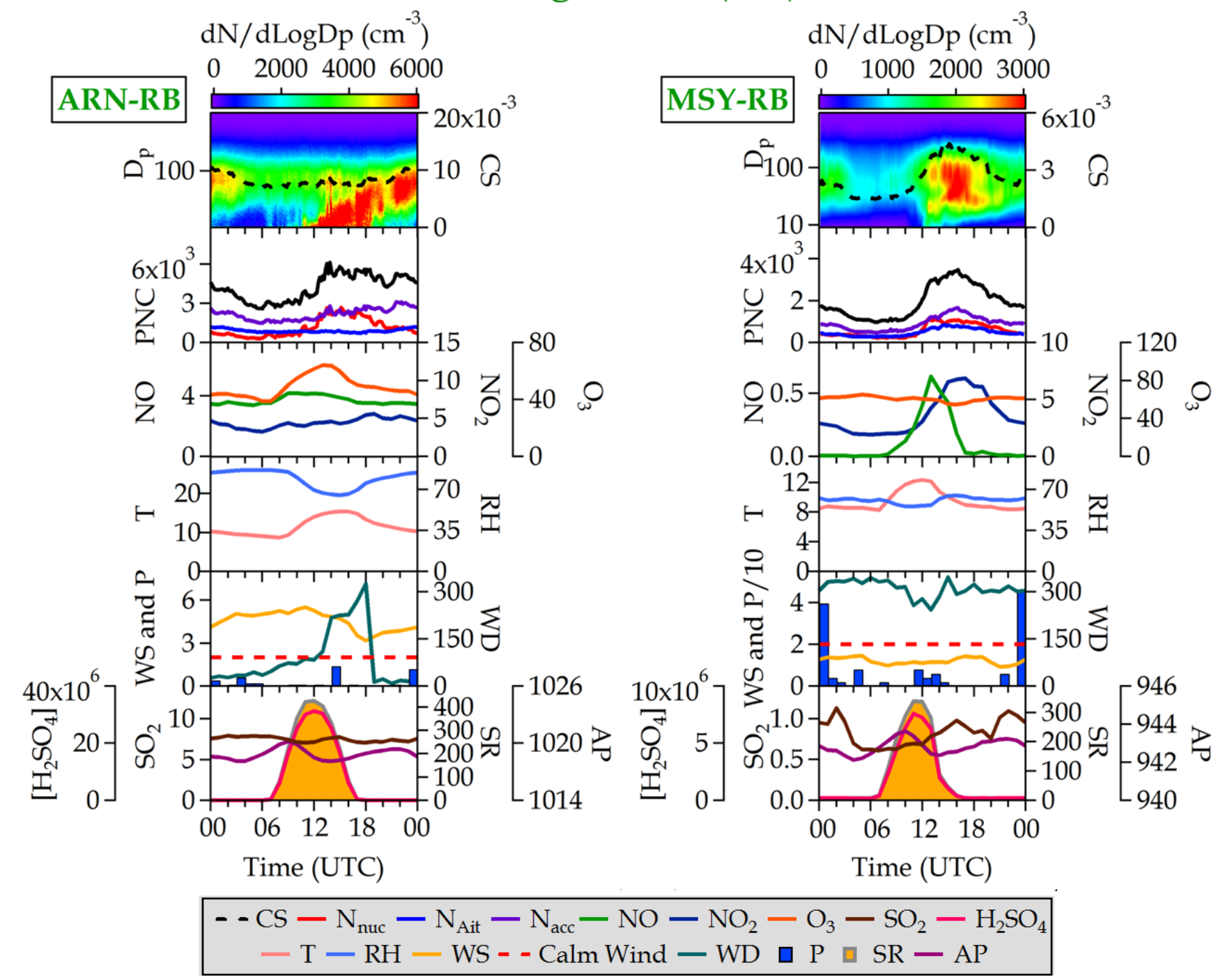


S3. Daily average of the entire cold REDMAAS field campaign data set for each site (ACN-UB, CIEMAT-UB, ARN-UB, BCN-UB, GRNUB, MSY-RB and IZAÑA-HA). Here, parameters are denoted as follows: $\mathrm{D}_{\mathrm{p}}=$ particle diameter $(\mathrm{nm}), \mathrm{CS}=\mathrm{condensation}$ sink $\left(\mathrm{s}^{-1}\right)$, PNC $=$ Particle Number Concentration $\left(\mathrm{cm}^{-3}\right), N_{t o t}=$ Particle Number Total Concentration $\left(\mathrm{cm}^{-3}\right), N_{n u c}=$ Nucleation-mode particles $\left(\mathrm{cm}^{-3}\right)$, $N_{\text {Ait }}=$ Aitken-mode particles $\left(\mathrm{cm}^{-3}\right), N_{a c c}=$ Accumulation-mode particles $\left(\mathrm{cm}^{-3}\right), \mathrm{T}=$ Temperature $\left({ }^{\circ} \mathrm{C}\right)$, HR= Relative Humidity $(\%)$, WS=Wind Speed $\left(\mathrm{m} \mathrm{s}^{-1}\right.$, Calm WS $\left.2 \mathrm{~m} \mathrm{~s}^{-1}\right)$, WD=Wind Direction (degrees), P=Precipitation (mm), SR= Solar Radiation $\left(\mathrm{W}\right.$ m $\left.{ }^{-2}\right)$ and AP=

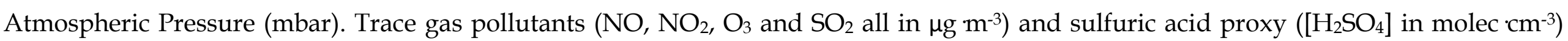
are also illustrated. 


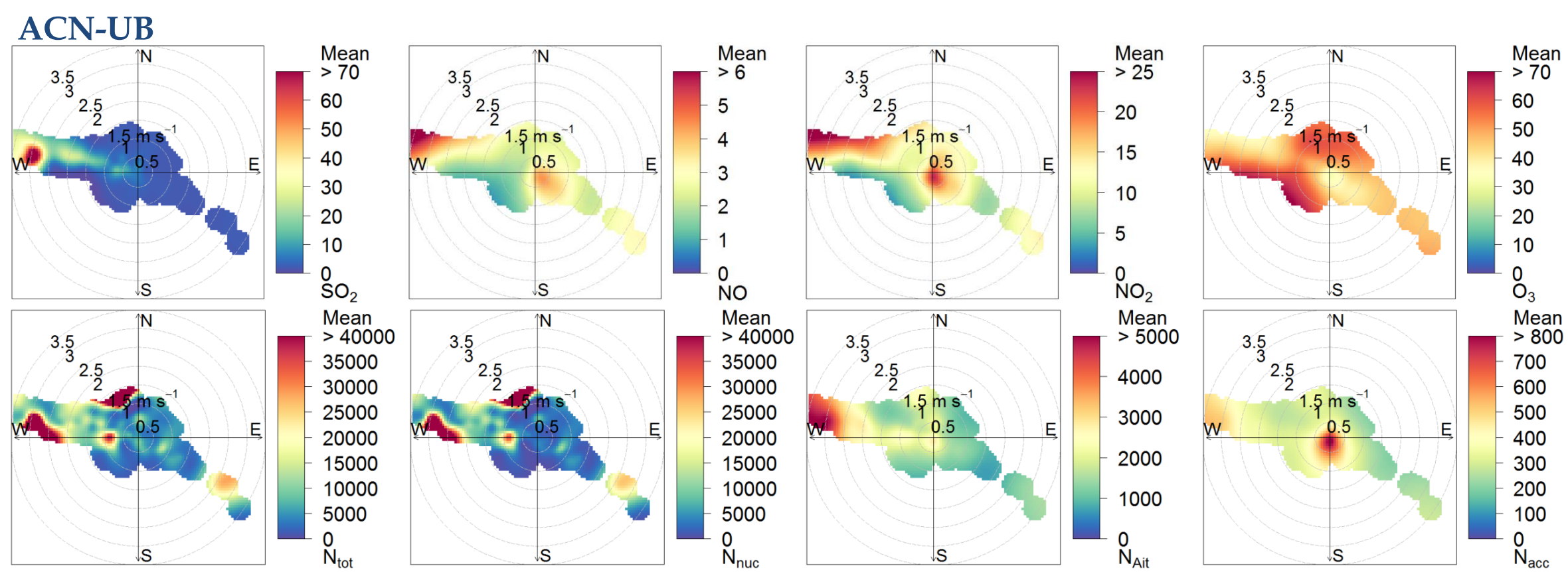




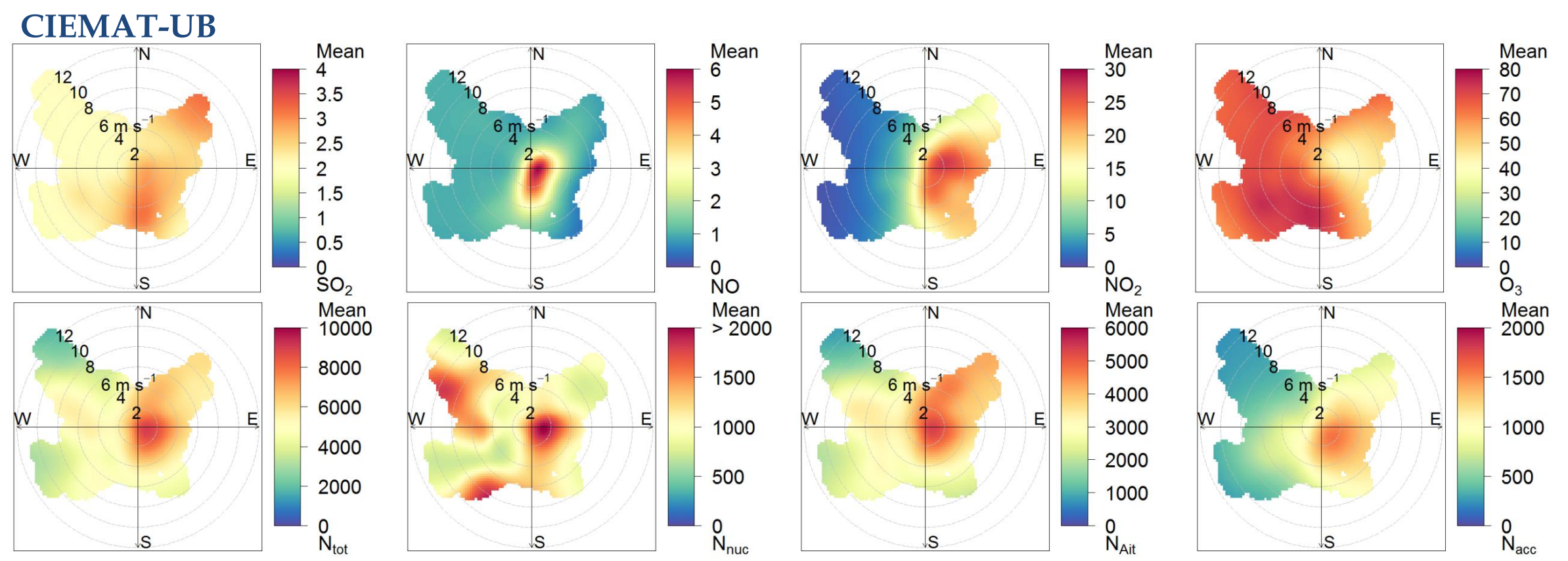



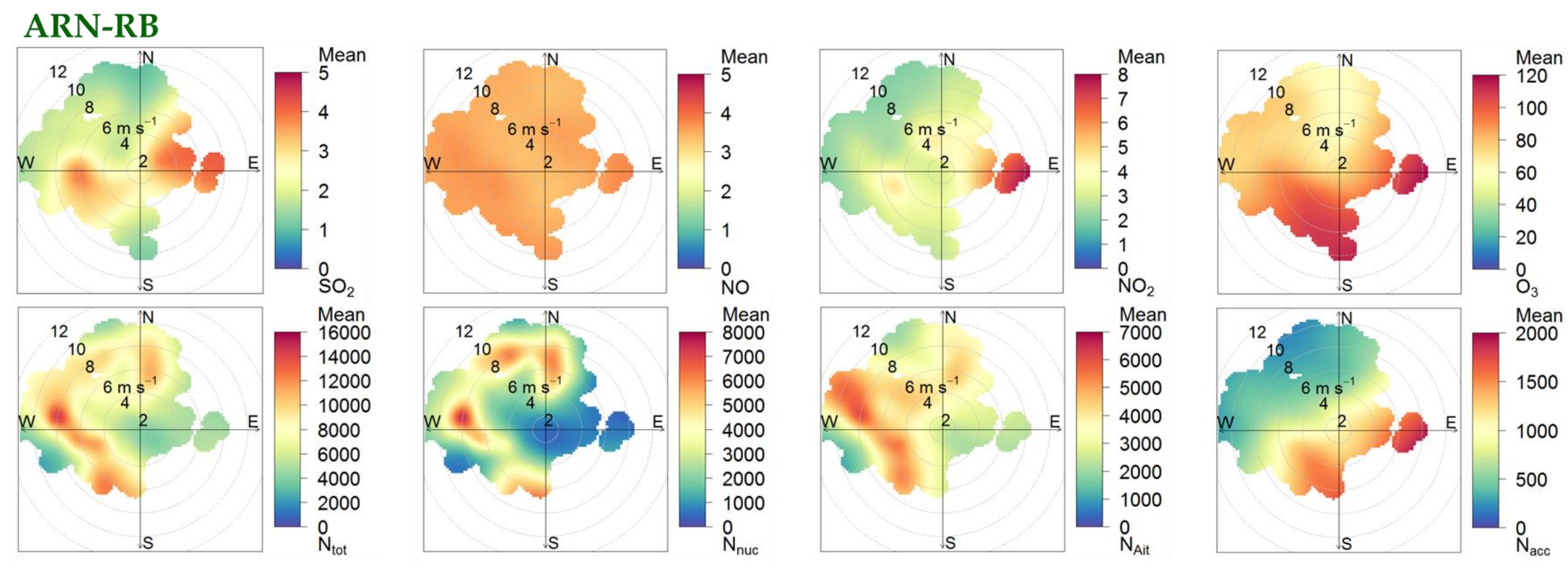

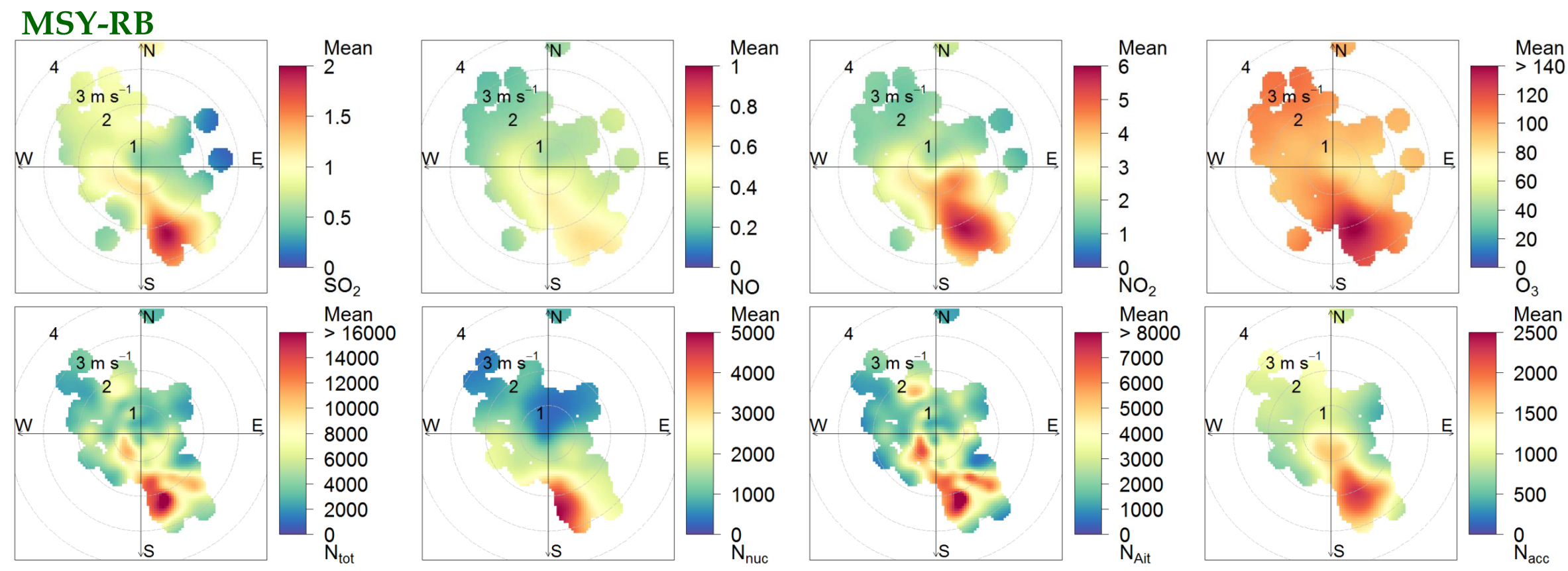


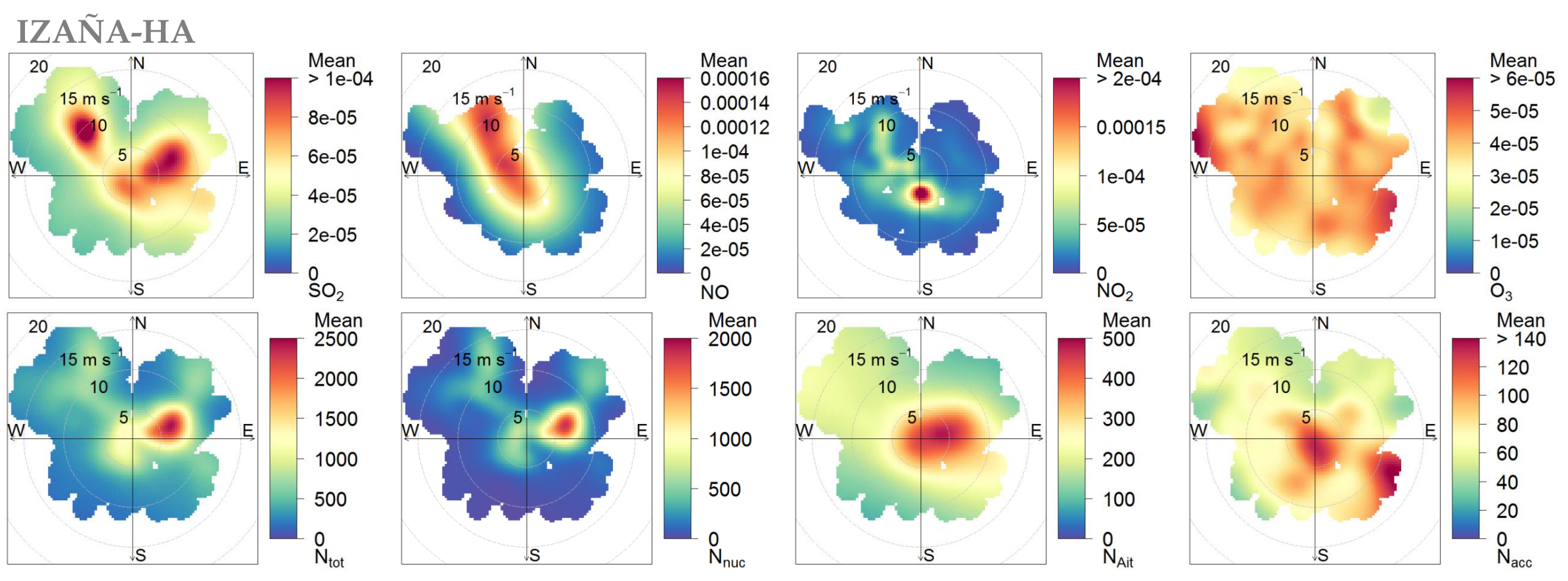

Fig. S4. Bivariate polar plots of trace gas pollutants $\left(\mu \mathrm{g} \mathrm{m}^{-3}\right)$ and PNCs $\left(\mathrm{cm}^{-3}\right)$ in all sites during the warm REDMAAS field campaign. 

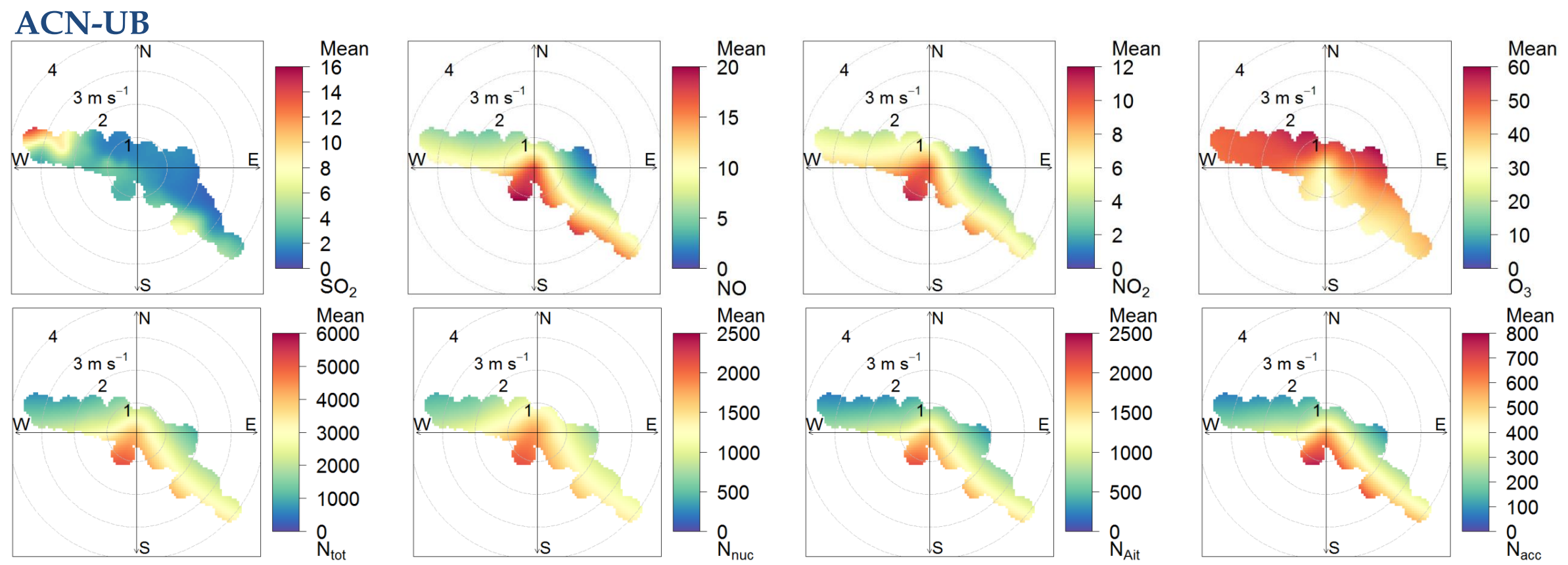


\section{CIEMAT-UB}
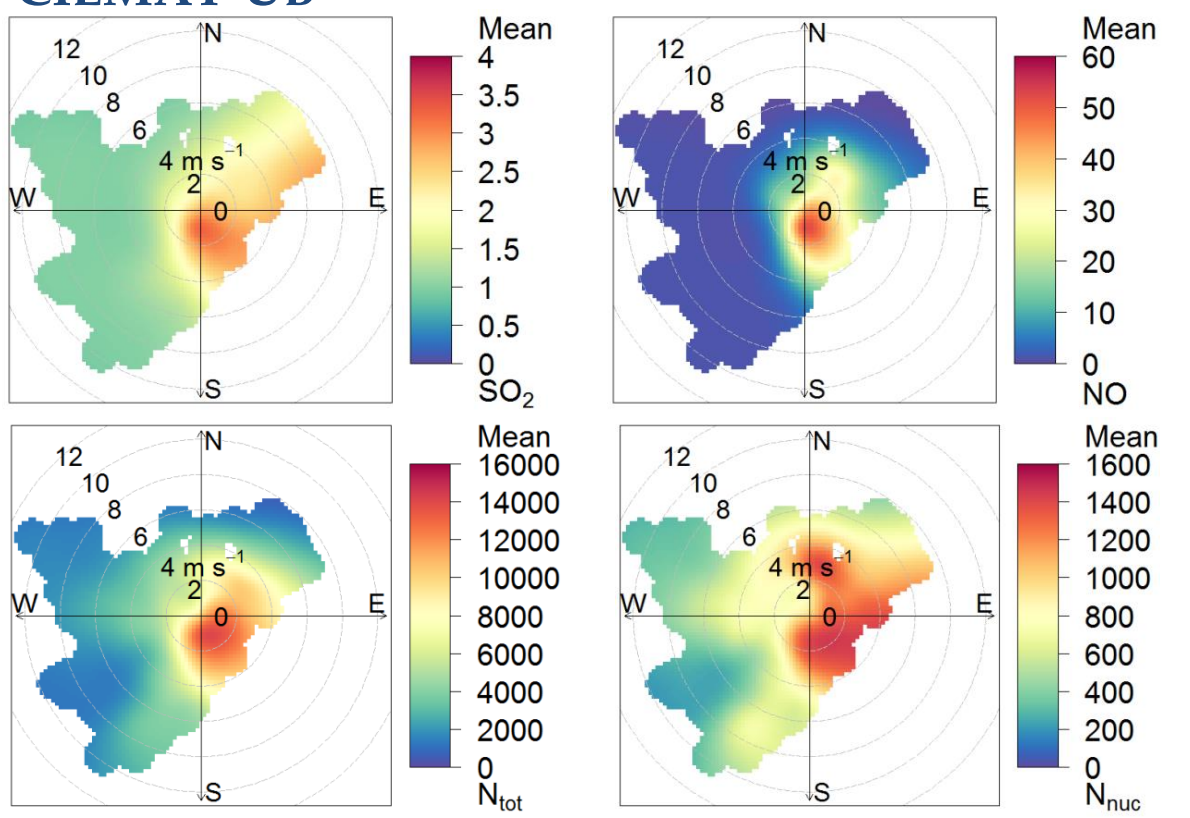
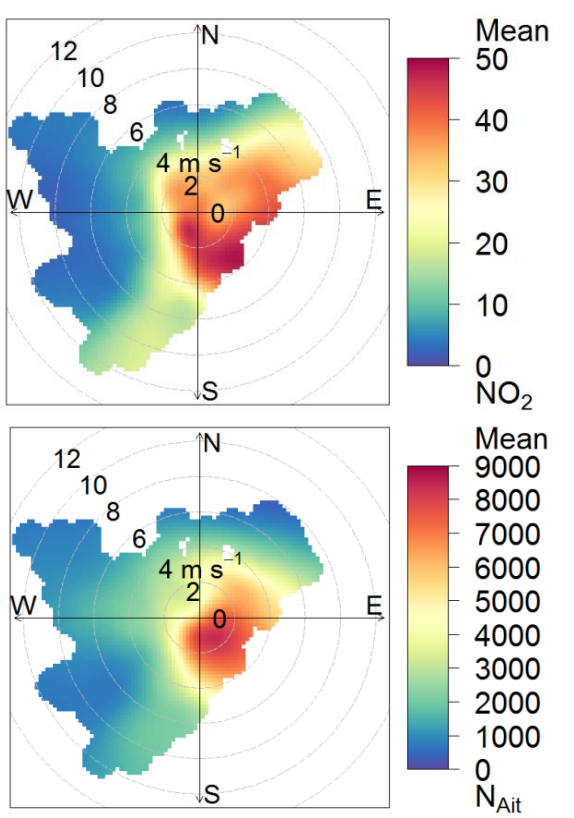

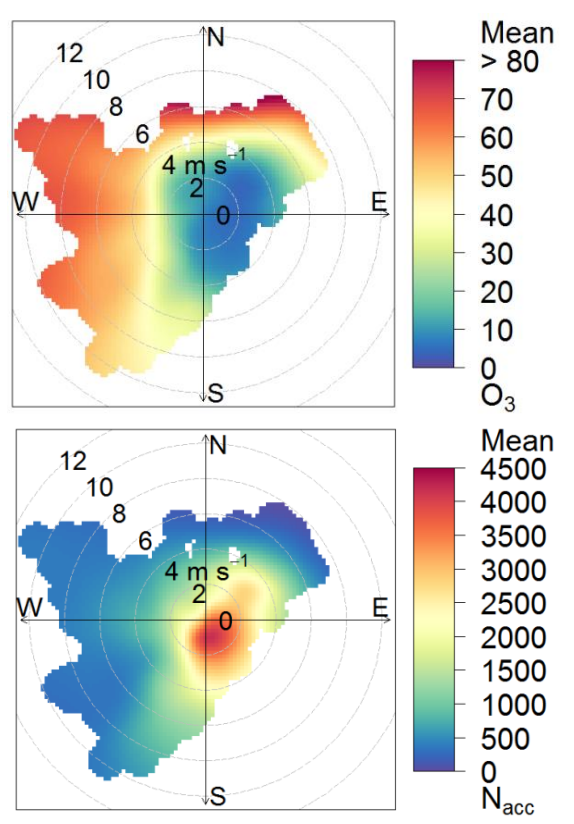



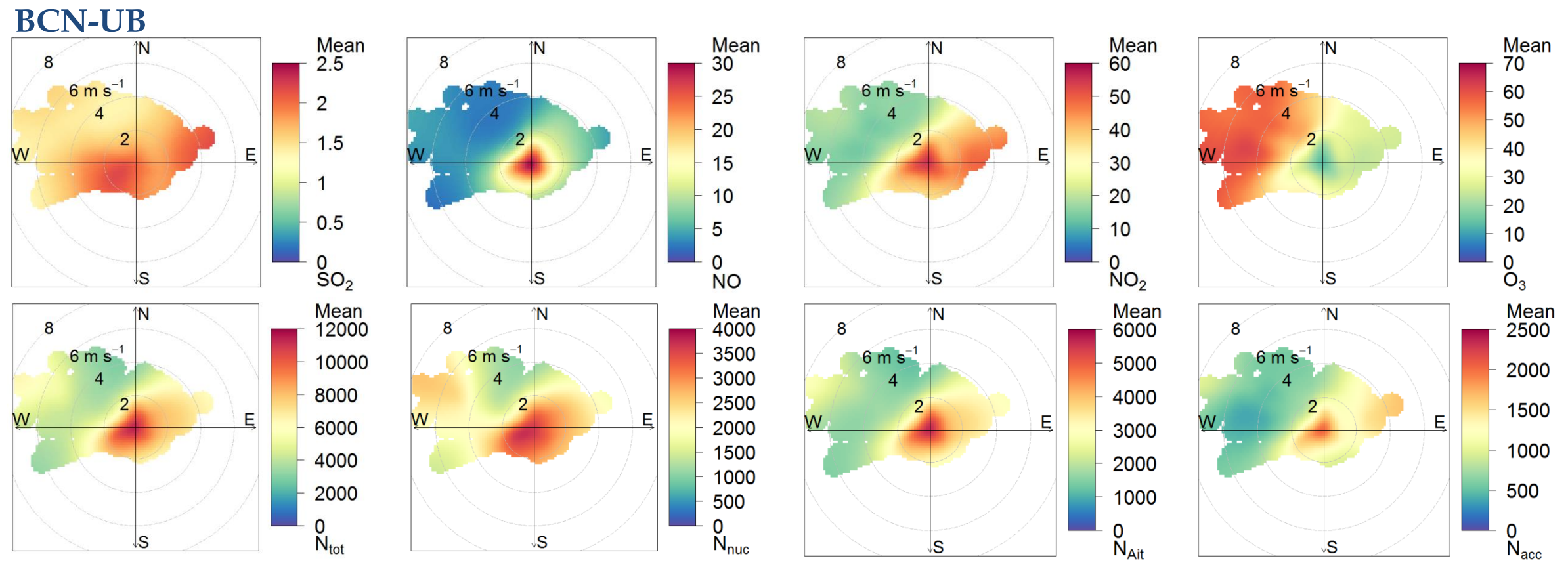


\section{GRN-UB}
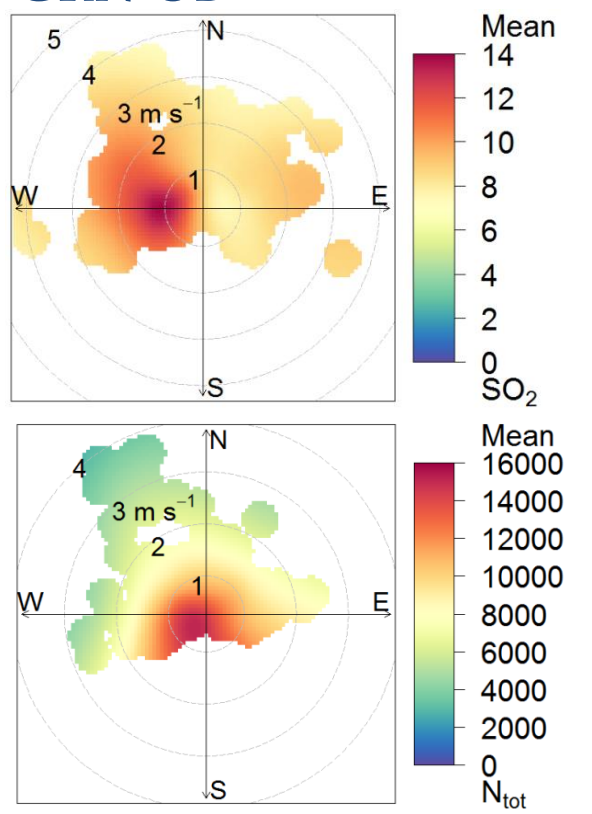

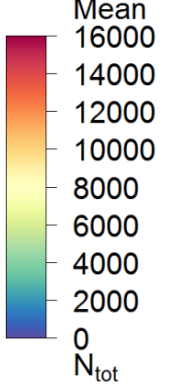

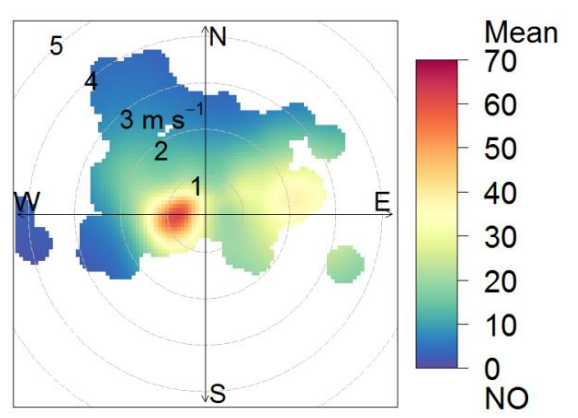
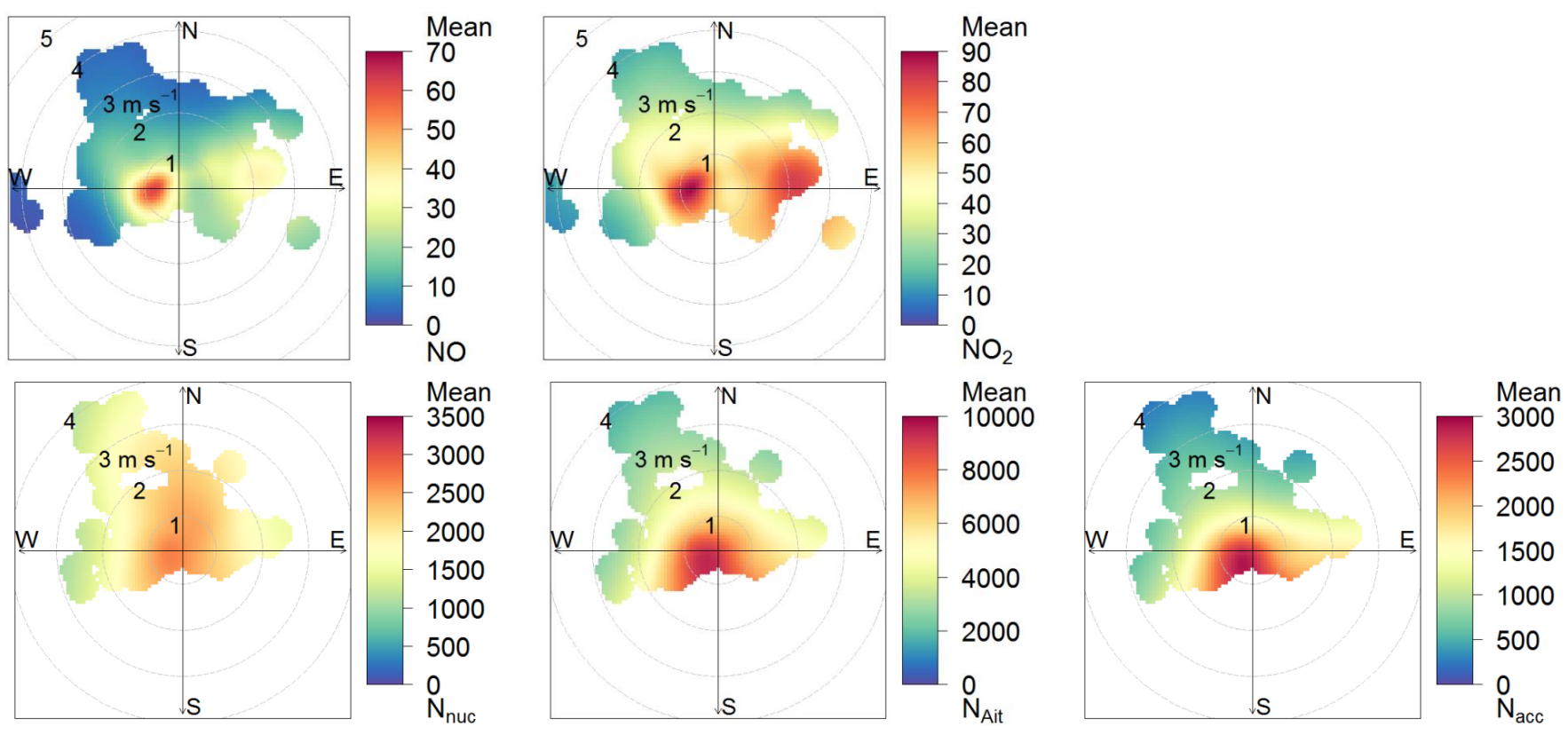

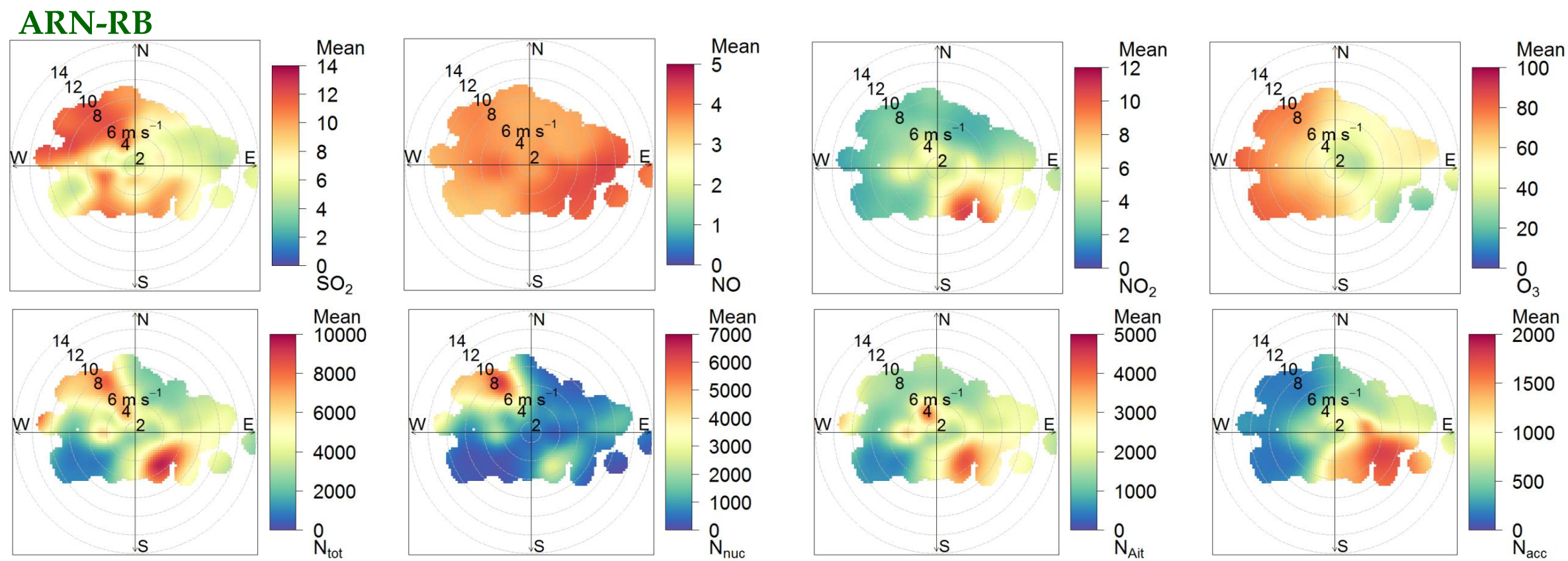

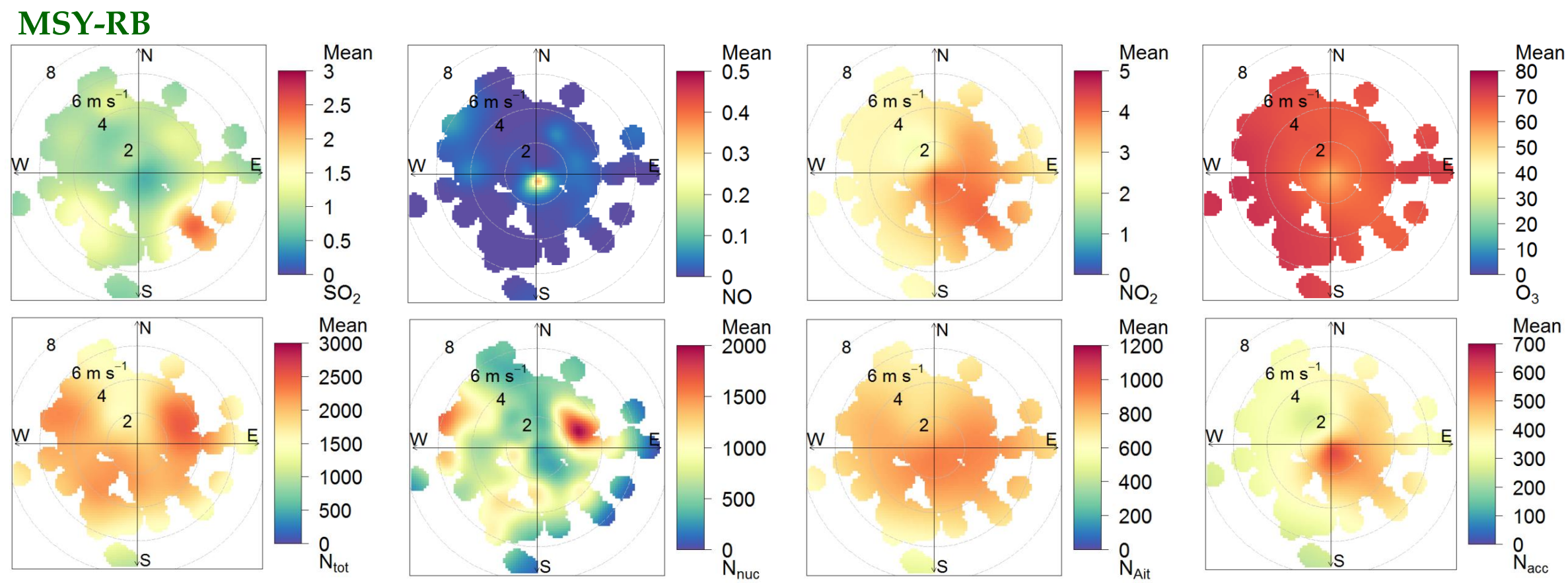


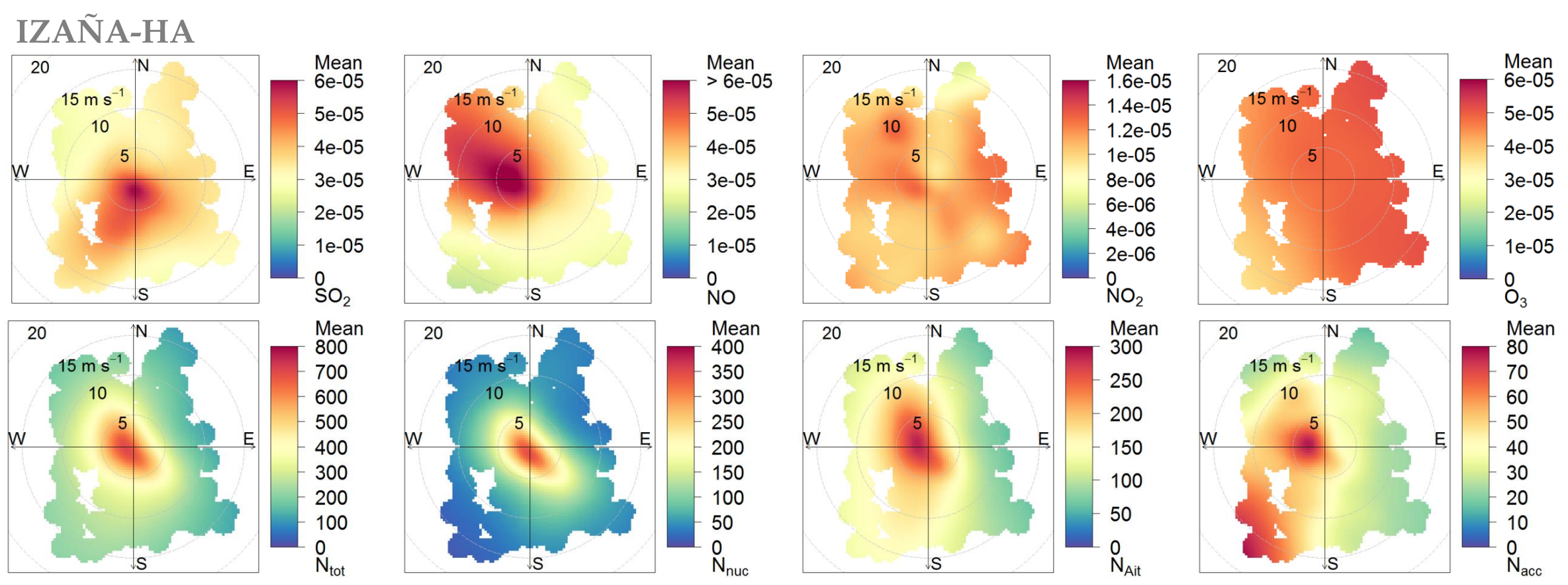

S5. Bivariate polar plots of trace gas pollutants $\left(\mu \mathrm{g} \mathrm{m}^{-3}\right)$ and PNCs $\left(\mathrm{cm}^{-3}\right)$ in all sites during the cold REDMAAS field campaign. 


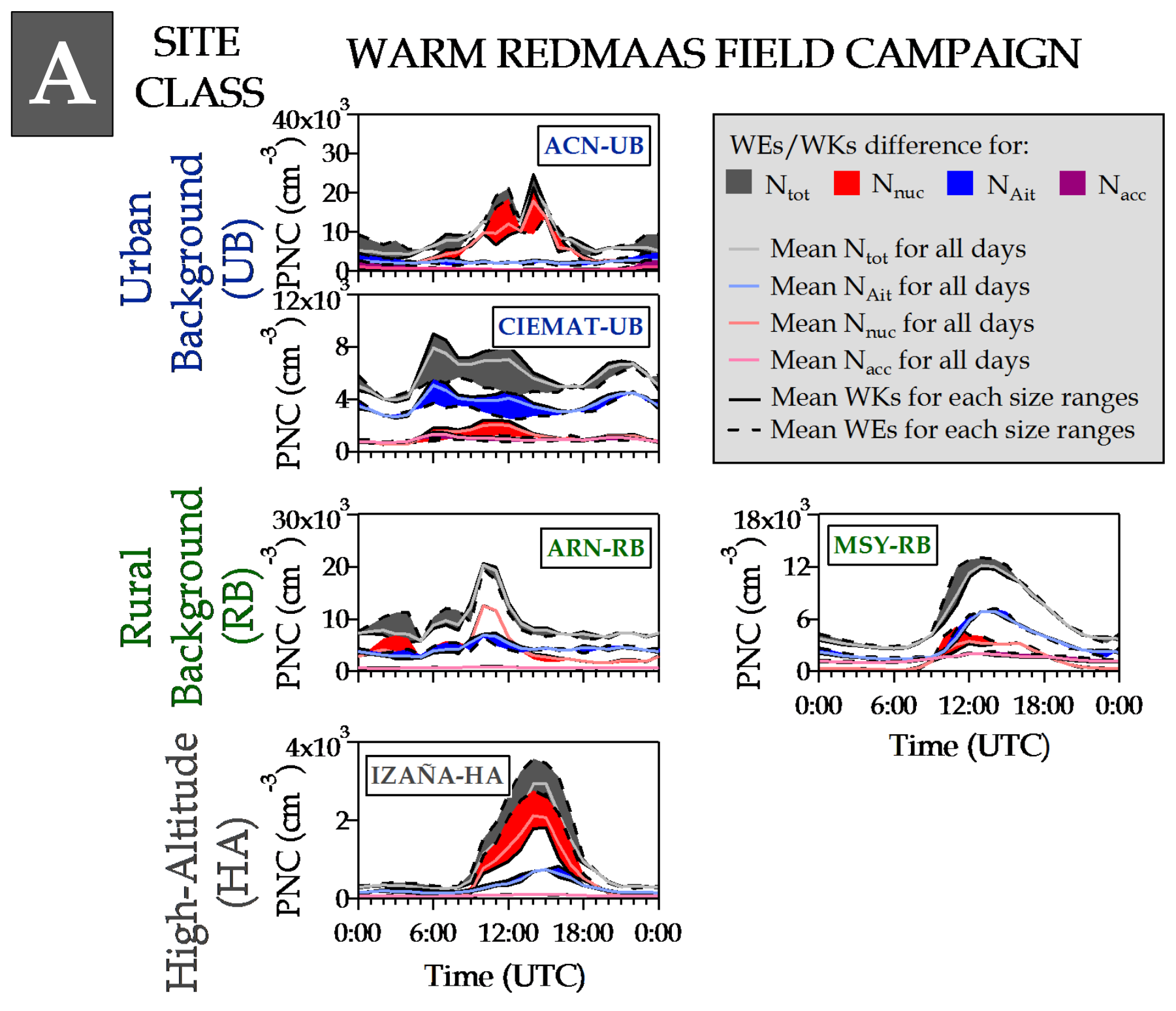




\section{B SITE COLD REDMAAS FIELD CAMPAIGN}
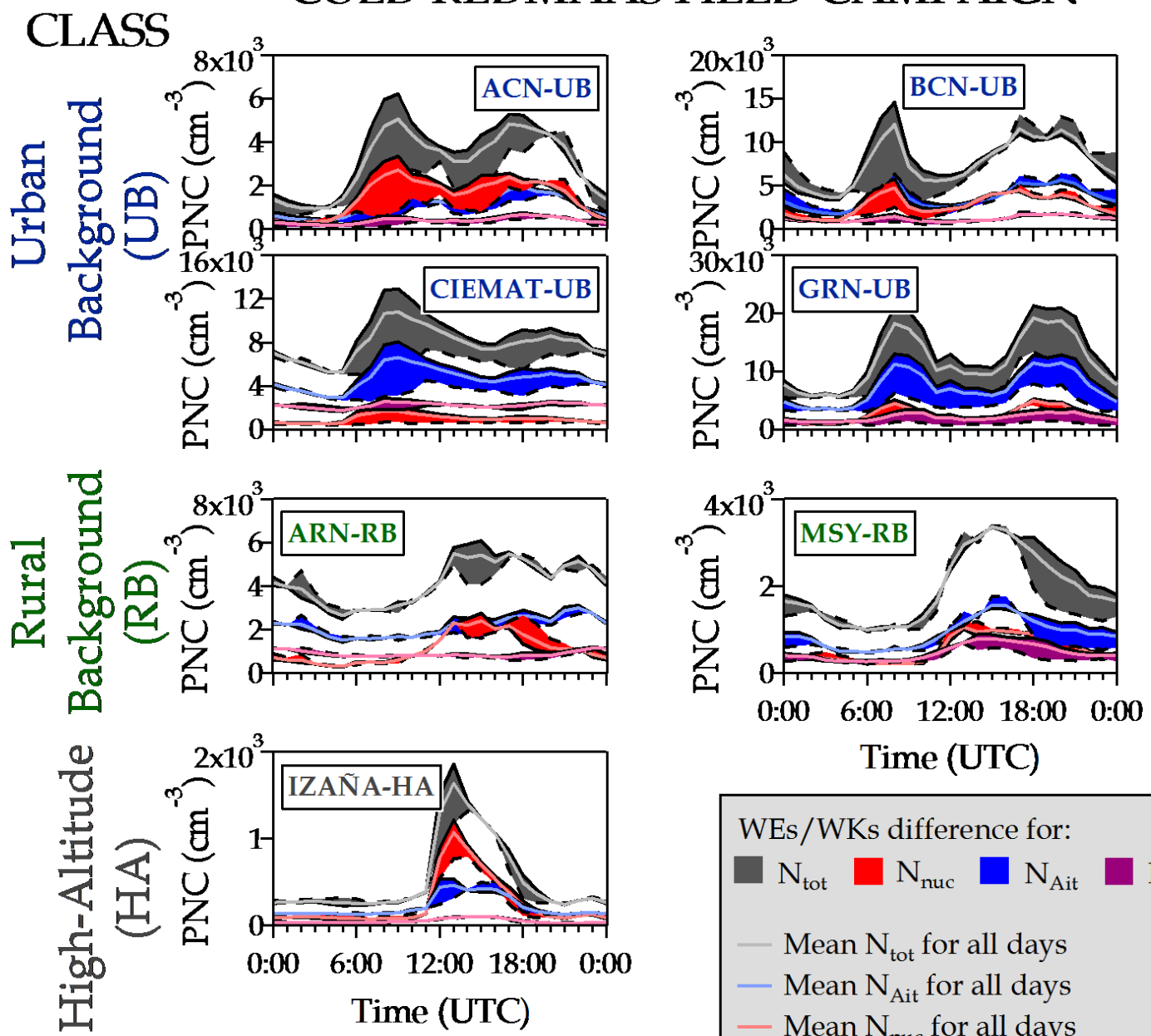

$$
\begin{aligned}
& \text { WEs/WKs difference for: } \\
& \mathrm{N}_{\text {tot }} \quad \mathrm{N}_{\text {nuc }} \quad \mathrm{N}_{\mathrm{Ait}} \\
& \text { - Mean } \mathrm{N}_{\text {tot }} \text { for all days } \\
& - \text { Mean } \mathrm{N}_{\text {Ait }} \text { for all days } \\
& - \text { Mean } \mathrm{N}_{\text {nuc }} \text { for all days } \\
& \text { - Mean } \mathrm{N}_{\text {acc }} \text { for all days } \\
& \text { - Mean WKs for each size ranges } \\
& \text { - - Mean WEs for each size ranges }
\end{aligned}
$$


Fig. S6. Daily variation of the 1-h mean total particle number concentration $\left(N_{t o t}\right)$ and per mode $\left(N_{\text {uuc }}, N_{\text {Ait }}\right.$ and $\left.N_{a c c}\right)$, for all period, workdays (WKs) and weekends (WEs) of each REDMAAS field campaigns: (A) warm and (B) cold campaigns. In the graph, the shaded areas represent the WEs (black dashed line)/WKs (black continuous line) difference for the different size ranges ( $N_{t o t}$ in grey, $N_{n u c}$ in red, $N_{A i t}$ in blue and $N_{a c c}$ in purple). The mean value of all days for each different size ranges has also been included in the graph. 


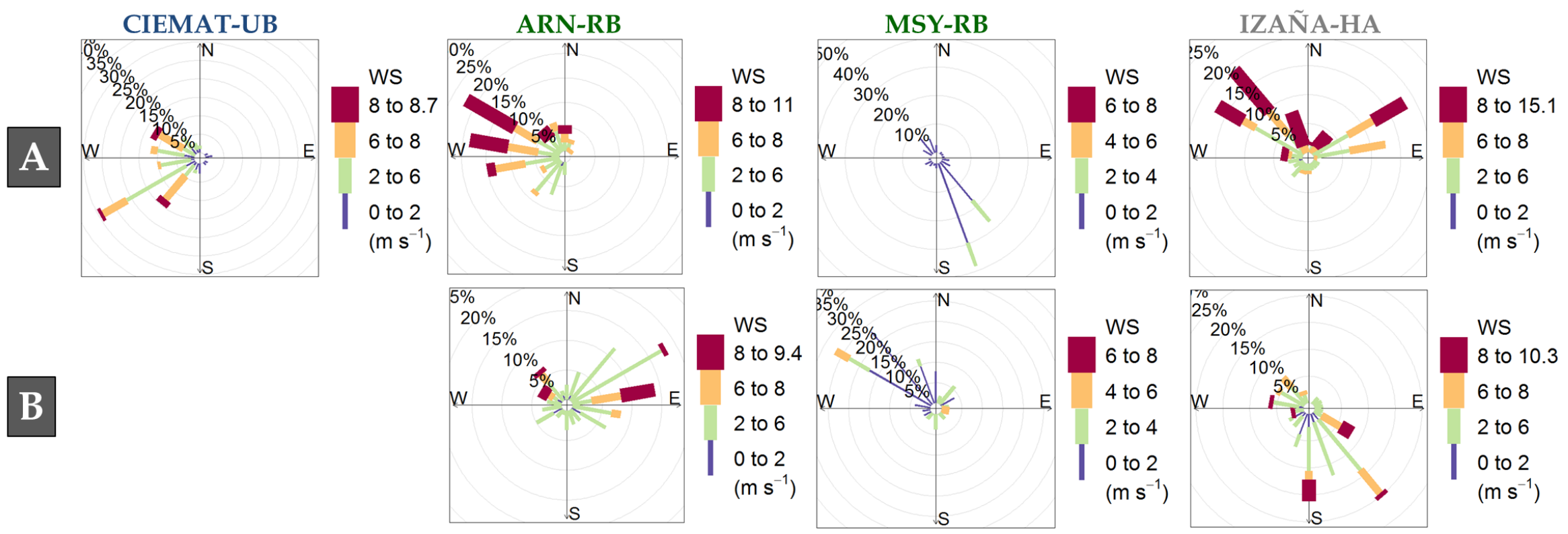

Fig. S7. Wind rose showing wind speed and direction statistics during the NPF events in CIEMAT-UB, ARN-RB, MSY-RB and IZAÑA-HA sites during the REDMAAS field campaigns: A) Warm REDMAAS field campaign and B) Cold REDMAAS field campaign. 


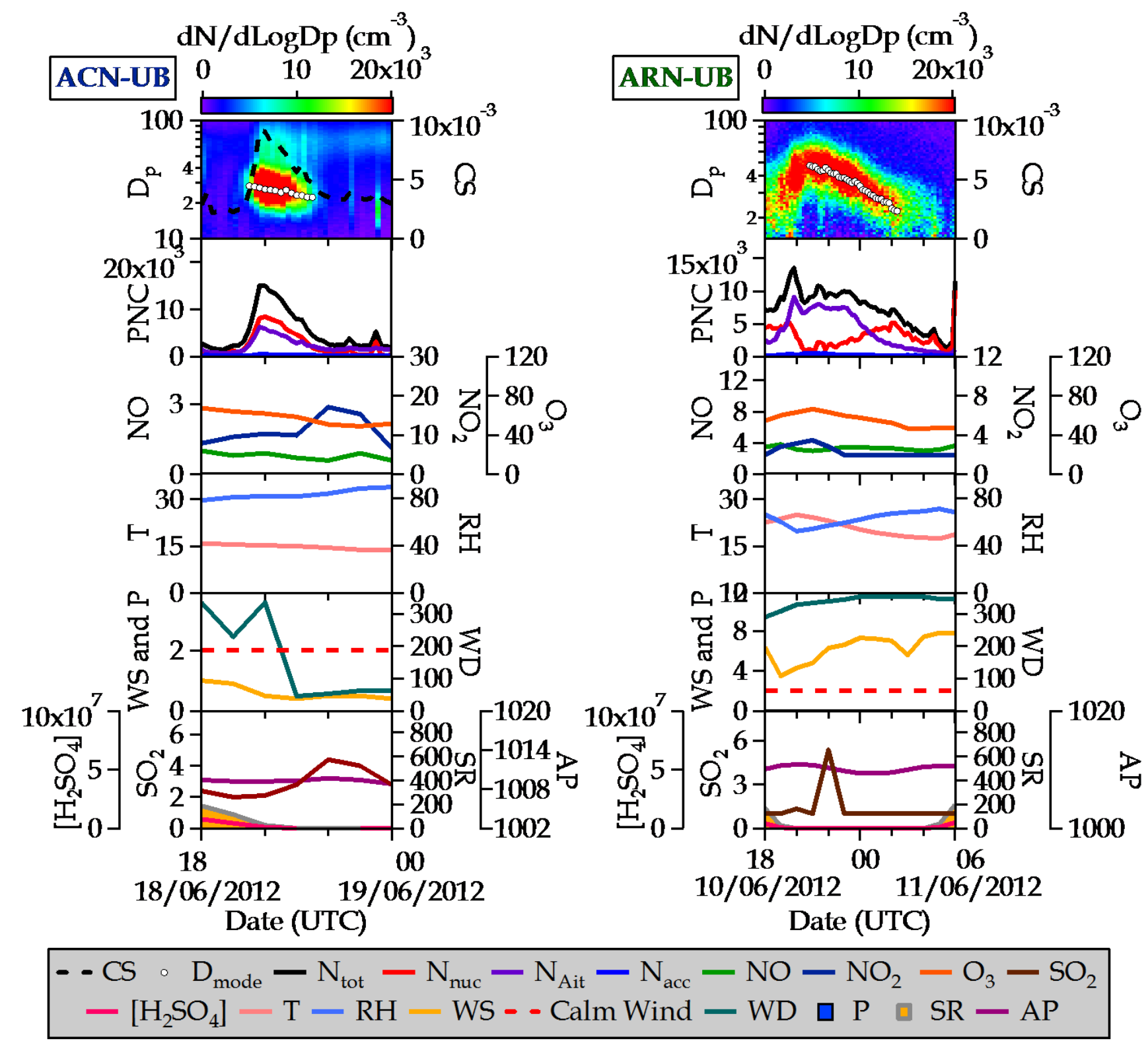


Fig. S8. Typical examples of aerosol particle shrinkage events (P-S) observed at ACN-UB and ARN-RB sites during the warm campaign. Parameters (units) are denoted in the graphs as follows: $\mathrm{Dp}=$ particle diameter $(\mathrm{nm}), D_{\text {mode }}=$ modal diameter of the measured particle number size distribution $(\mathrm{nm}), \mathrm{CS}=$ condensation sink $\left(\mathrm{s}^{-1}\right), \mathrm{PNC}=$ Particle Number Concentration $\left(\mathrm{cm}^{-3}\right), N_{\text {tot }}=$ Particle Number Total Concentration $\left(\mathrm{cm}^{-3}\right), N_{\text {uuc }}=$ Nucleation-mode particles $\left(\mathrm{cm}^{-3}\right), N_{\text {Ait }}=$ Aitken-mode particles $\left(\mathrm{cm}^{-3}\right), N_{\text {acc }}=$ Accumulation-mode particles $\left(\mathrm{cm}^{-3}\right), \mathrm{T}=$ Temperature $\left({ }^{\circ} \mathrm{C}\right), \mathrm{HR}=$ Relative Humidity $(\%), \mathrm{WS}=$ Wind Speed $\left(\mathrm{m} \mathrm{s}^{-1}, \mathrm{Calm} \mathrm{WS}<2 \mathrm{~m} \mathrm{~s}^{-1}\right), \mathrm{WD}=$ Wind Direction (degrees), $\mathrm{P}=$ Precipitation $(\mathrm{mm}), \mathrm{SR}=$ Solar Radiation $\left(\mathrm{W} \cdot \mathrm{m}^{-2}\right)$ and $\mathrm{AP}=$ Atmospheric Pressure (mbar). Trace gas pollutants $\left(\mathrm{NO}, \mathrm{NO}_{2}, \mathrm{O}_{3}\right.$ and $\mathrm{SO}_{2}$, all in $\left.\mu \mathrm{g} \cdot \mathrm{cm}^{-3}\right)$ and sulfuric acid proxy $\left(\left[\mathrm{H}_{2} \mathrm{SO}_{4}\right]\right.$ in molecules $\left.\cdot \mathrm{cm}^{-3}\right)$ are also presented. 
2 Table S1. List of symbols and acronyms used in this study.

\begin{tabular}{|c|c|}
\hline Acronym & Description \\
\hline \multicolumn{2}{|r|}{ Sites } \\
\hline ACN-UB & A Coruña Urban Background site \\
\hline CIEMAT-UB & CIEMAT (Madrid) Urban Background site \\
\hline BCN-UB & Barcelona Urban Background site \\
\hline GRN-UB & Granada Urban Background site \\
\hline ARN-RB & Arenosillo (Huelva) Rural Background site \\
\hline MSY-RB & Montseny (Barcelona) Rural Background site \\
\hline IZAÑA-HA & Izaña (Canary Islands) Hight Altitude site \\
\hline \multicolumn{2}{|r|}{ Parameters (units) } \\
\hline PNSD & Particle number size distribution $\left(\mathrm{cm}^{-3}\right)$ \\
\hline$D_{\text {mode }}$ & Modal diameter of the PNSD measured (nm) \\
\hline ER & Evaporation rate $\left(\mathrm{nm} \cdot \mathrm{h}^{-1}\right)$ \\
\hline GR & Growth rate $\left(\mathrm{nm} \cdot \mathrm{h}^{-1}\right)$ \\
\hline CS & Condensation Sink $\left(\mathrm{s}^{-1}\right)$ \\
\hline PNC & Particle Number Concentration $\left(\mathrm{cm}^{-3}\right)$ \\
\hline$N_{t o t}$ & Particle Number Total Concentration $\left(\mathrm{cm}^{-3}\right)$ \\
\hline$N_{n u c}$ & Nucleation-mode particles, up to $30 \mathrm{~nm}\left(\mathrm{~cm}^{-3}\right)$ \\
\hline
\end{tabular}




\begin{tabular}{cl}
$N_{A i t}$ & Aitken-mode particles, between 30 and $100 \mathrm{~nm}\left(\mathrm{~cm}^{-3}\right)$ \\
$N_{a c c}$ & Accumulation-mode particles, above $100 \mathrm{~nm}\left(\mathrm{~cm}^{-3}\right)$ \\
$\mathrm{T}$ & Temperature $\left({ }^{\circ} \mathrm{C}\right)$ \\
$\mathrm{RH}$ & Relative Humidity $(\mathrm{RH})$ \\
$\mathrm{P}$ & Precipitation (mm) \\
$\mathrm{WS}$ & Wind Speed (WS) \\
$\mathrm{WD}$ & Wind Direction (WD) \\
$\mathrm{SR}$ & Solar Radition (W m$\left.{ }^{-2}\right)$ \\
$\mathrm{AP}$ & Atmospheric Pressure (mbar) \\
{$\left[\mathrm{H}_{2} \mathrm{SO}_{4}\right]$} & Estimation of sulfuric acid in gas phase $\left(\right.$ molec $\left.\mathrm{cm}^{-3}\right)$ \\
\hline & $\quad$ Others \\
\hline WKs & Workdays (Monday-Friday) \\
WEs & Weekends (Saturday-Sunday)
\end{tabular}


4 Table S2. Details of the instrumentation used during the REDMAAS field. Further information about this instrumentation can be

5 found in Gómez-Moreno et al. (2015).

\begin{tabular}{|c|c|c|c|c|c|c|c|c|}
\hline \multirow{2}{*}{ Monitoring site } & \multirow{2}{*}{ Equipment } & \multirow{2}{*}{$\begin{array}{c}\text { Impactor } \\
\text { (nozzle size in } \mathrm{cm})\end{array}$} & \multicolumn{2}{|c|}{ Dryer } & \multirow{2}{*}{$\begin{array}{l}\text { Flows rate } \\
(\mathrm{L} / \mathrm{min})\end{array}$} & \multirow{2}{*}{$\begin{array}{l}\text { Nominal } \\
\text { size range }\end{array}$} & \multirow{2}{*}{$\begin{array}{l}\text { Channels } \\
\text { per decade }\end{array}$} & \multirow{2}{*}{$\begin{array}{l}\text { SMPS time } \\
\text { resolution } \\
\quad(\mathrm{min})\end{array}$} \\
\hline & & & Aerosol Flow & Sheath Flow & & & & \\
\hline ACN-RB & $\begin{array}{l}\text { TSI-SMPS Model 3936L: } \\
\text { DMA 3081+CPC } 3785\end{array}$ & 0.0508 & $\begin{array}{c}\text { Yes } \\
\text { (nafion) }\end{array}$ & No & $1: 10$ & $\begin{array}{c}17.64-289 \\
27.37-299.6\end{array}$ & 64 & 4.5 \\
\hline CIEMAT-UB & $\begin{array}{l}\text { TSI-SMPS Model 3936: } \\
\text { DMA 3081+CPC } 3775\end{array}$ & 0.071 & $\begin{array}{c}\text { Yes } \\
\text { (nafion) }\end{array}$ & $\begin{array}{c}\text { Yes } \\
\text { (silica gel) }\end{array}$ & $1: 10$ & $20.2-661.2$ & 64 & 4.5 \\
\hline BCN-UB & $\begin{array}{l}\text { TSI-SMPS Model 3936: } \\
\text { DMA 3081+CPC } 3772\end{array}$ & 0.071 & No & No & 1:5 & $10.9-478.3$ & 64 & 5 \\
\hline GRN-UB & TSI- UFP 3031 & & & & 5 & $20->200$ & 6 & 10 \\
\hline ARN-RB & $\begin{array}{l}\text { TSI-SMPS Model 3936: } \\
\text { DMA 3081+CPC3776 }\end{array}$ & 0.0508 & Yes & Yes & $1: 10$ & $14.1-736.5$ & 64 & 10 \\
\hline \multirow{2}{*}{ MSY-RB } & $\begin{array}{l}\text { TSI-SMPS Model 3936: } \\
\text { DMA 3081+CPC } 3772^{1}\end{array}$ & Not Used & $\begin{array}{c}\text { Yes } \\
\text { (nafion) }\end{array}$ & No & $1: 5$ & $10.9-478.3$ & 64 & 4.5 and 5 \\
\hline & $\begin{array}{c}\text { SMPS-IfT: } \\
\text { DMA-IfT+CPC } 3772^{2}\end{array}$ & Not Used & $\begin{array}{c}\text { Yes } \\
\text { (nafion) }\end{array}$ & Yes & $1: 5$ & $9.02-855.78$ & 38 & 5 \\
\hline IZAÑA-HA & $\begin{array}{l}\text { TSI-SMPS Model 3936: } \\
\text { DMA 3081+CPC } 3010\end{array}$ & Not used & Not needed & Not needed & $1: 5$ & $10.6-495.8$ & 64 & 5 \\
\hline
\end{tabular}

$6 \quad{ }^{1}$ In warm period/2In cold period. 
7 Table S3. Information of the additional measurements available, both gases and meteorological parameter, at the different sites.

8 Here, the data coverage of these data set for the different sites and periods $(\mathrm{W}=$ warm REDMAAS field campaign $\mathrm{C}=\mathrm{cold}$

9 REDMAAS field campaign) has also been included.

10

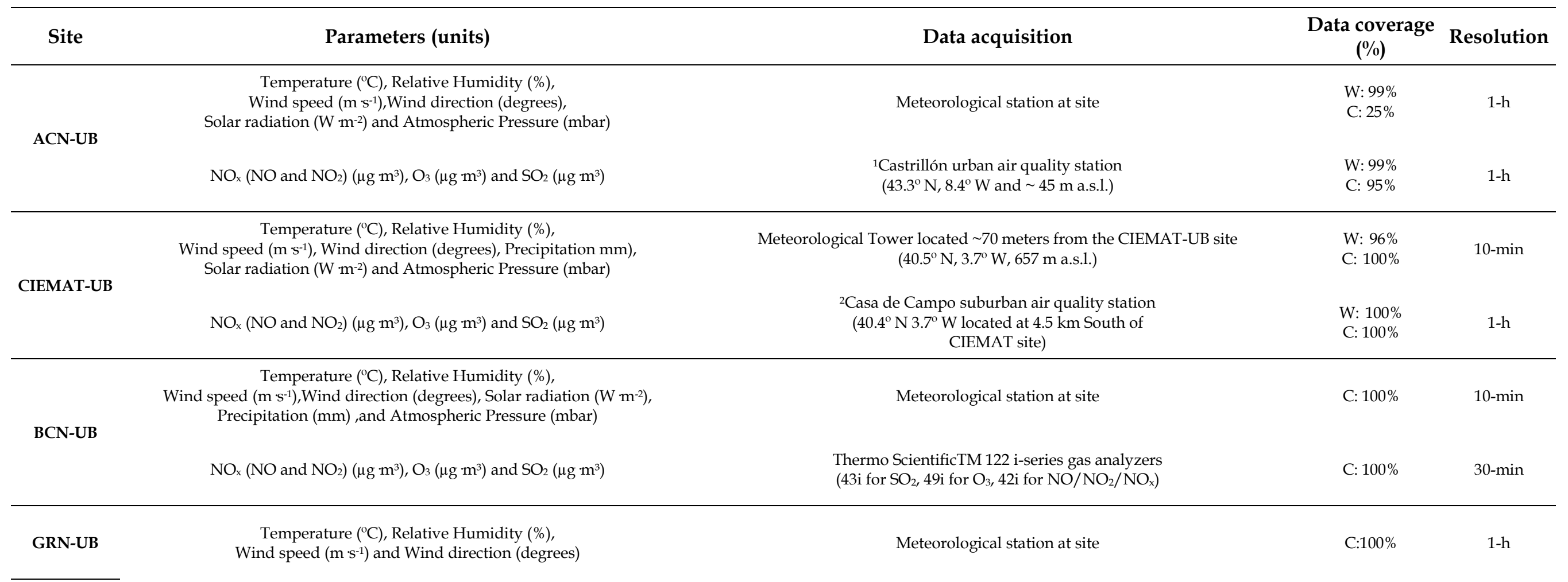


Wind speed $\left(\mathrm{m} \mathrm{s}^{-1}\right)$,Wind direction (degrees), Solar radiation $\left(\mathrm{W} \mathrm{m}^{-2}\right)$,

ARN-RB Precipitation $(\mathrm{mm})$ and Atmospheric Pressure (mbar) Wind speed $\left(\mathrm{m} \mathrm{s}^{-1}\right)$,Wind direction (degrees), Solar radiation $\left(\mathrm{W} \mathrm{m}^{-2}\right)$,

MSY-RB

$\mathrm{NO}_{\times}\left(\mathrm{NO}\right.$ and $\left.\mathrm{NO}_{2}\right)\left(\mu \mathrm{g} \mathrm{m}^{3}\right), \mathrm{O}_{3}\left(\mu \mathrm{g} \mathrm{m} \mathrm{m}^{3}\right)$ and $\mathrm{SO}_{2}\left(\mu \mathrm{g} \mathrm{m} \mathrm{m}^{3}\right)$
Thermo Scientific TM 122 i-series gas analyzers (43i for $\mathrm{SO}_{2}, 49 \mathrm{i}$ for $\mathrm{O}_{3}, 42 \mathrm{i}$ for $\mathrm{NO} / \mathrm{NO}_{2} / \mathrm{NO}_{\mathrm{x}}$ )
W: $100 \%$

W: $77 \%$

C: $100 \%$

30-min

\footnotetext{
Temperature $\left({ }^{\circ} \mathrm{C}\right)$, Relative Humidity $(\%)$

Wind speed $\left(\mathrm{m} \mathrm{s}^{-1}\right)$, Wind direction (degrees) and Atmospheric Pressure (mbar)

\section{IZAÑA-HA}

$\mathrm{NO}_{x}\left(\mathrm{NO}\right.$ and $\left.\mathrm{NO}_{2}\right)\left(\mu \mathrm{g} \mathrm{m}^{3}\right), \mathrm{O}_{3}\left(\mu \mathrm{g} \mathrm{m}^{3}\right)$ and $\mathrm{SO}_{2}\left(\mu \mathrm{g} \mathrm{m}^{3}\right)$

Meteorological station at site

$\mathrm{W}: 100 \%$

C. $93 \%$

11 1Air quality station belonging to the A Coruña air quality monitoring network.

12 2Air quality station belonging to the Madrid air quality monitoring network.

13 Air quality station belonging to the Granada air quality monitoring network. 
${ }^{4}$ Air quality station belonging to the Huelva air quality monitoring network.

15 
16 Table S4 Mean of the total $\left(N_{t o t}\right)$ and modal $\left(N_{n u c}, N_{A i t}\right.$ and $\left.N_{a c c}\right)$ particle concentration at the seven studied sites during the

17 REDMAAS field campaigns. The standard deviation of each quantity is given in parentheses. $N_{n u c}, N_{A i t}$ and $N_{a c c} / N_{t o t}$ in $\%$ have

18 been included.

\begin{tabular}{|c|c|c|c|c|c|c|c|}
\hline $\begin{array}{l}\text { PNC } \\
\left(\mathrm{cm}^{-3}\right)\end{array}$ & ACN-UB & CIEMAT-UB & BCN-UB & GRN-RB & ARN-RB & MSY-RB & IZAÑA-HA \\
\hline \multicolumn{8}{|c|}{ Warm REDMAAS field campaign } \\
\hline$N_{t o t}$ & $8385 \pm 5667$ & $5889 \pm 1444$ & & & $8868 \pm 3716$ & $6032 \pm 1586$ & $889 \pm 654$ \\
\hline$N_{\text {nuc }}$ & $5373 \pm 4857(64 \%)$ & $1222 \pm 401(21 \%)$ & & & $3900 \pm 2214(44 \%)$ & $1440 \pm 711(24 \%)$ & $518 \pm 535(58 \%)$ \\
\hline$N_{\text {Ait }}$ & $2388 \pm 1288(28 \%)$ & $3707 \pm 1023(63 \%)$ & & & $4259 \pm 2010(48 \%)$ & $3188 \pm 1120(53 \%)$ & $289 \pm 165(33 \%)$ \\
\hline$N_{a c c}$ & $623 \pm 773(7 \%)$ & $960 \pm 434(16 \%)$ & & & $710 \pm 499(8 \%)$ & $1405 \pm 516(23 \%)$ & $82 \pm 30(9 \%)$ \\
\hline \multicolumn{8}{|c|}{ Cold REDMAAS field campaign } \\
\hline$N_{t o t}$ & $3177 \pm 1265$ & $7890 \pm 4703$ & $7749 \pm 3059$ & $11764 \pm 4706$ & $4141 \pm 1763$ & $1944 \pm 776$ & $519 \pm 356$ \\
\hline$N_{n u c}$ & $1595 \pm 614(50 \%)$ & $991 \pm 589(13 \%)$ & $2839 \pm 1141(37 \%)$ & $2475 \pm 551(21 \%)$ & $1125 \pm 958(27 \%)$ & $554 \pm 394(29 \%)$ & $248 \pm 250(48 \%)$ \\
\hline$N_{\text {Ait }}$ & $1183 \pm 516(37 \%)$ & $4682 \pm 2900(59 \%)$ & $3677 \pm 1590(47 \%)$ & $7207 \pm 3012(61 \%)$ & $2142 \pm 857(52 \%)$ & $912 \pm 395(47 \%)$ & $217 \pm 120(42 \%)$ \\
\hline$N_{a c c}$ & $399 \pm 185(13 \%)$ & $2218 \pm 1569(28 \%)$ & $1233 \pm 561(16 \%)$ & $2082 \pm 1284(18 \%)$ & $875 \pm 482(21 \%)$ & $478 \pm 298(25 \%)$ & $54 \pm 24(10 \%)$ \\
\hline
\end{tabular}


19 Table S5. Mean of the total $\left(N_{t o t}\right)$ and modal $\left(N_{n u c}, N_{\text {Ait }}\right.$ and $\left.N_{a c c}\right)$ particle concentration at the seven studied sites for workdays

20 (WKs) and weekends (WEs) during the REDMAAS field campaigns. The standard deviation of each quantity is given in

21 parentheses. WEs/WKs differences in \% have been included.

\begin{tabular}{|c|c|c|c|c|c|c|c|c|c|c|c|c|c|c|}
\hline \multirow{2}{*}{$\begin{array}{l}\text { PNC } \\
\left(\mathrm{cm}^{-3}\right)\end{array}$} & \multicolumn{2}{|c|}{ ACN-UB } & \multicolumn{2}{|c|}{ CIEMAT-UB } & \multicolumn{2}{|c|}{ BCN-UB } & \multicolumn{2}{|c|}{ GRN-RB } & \multicolumn{2}{|c|}{ ARN-RB } & \multicolumn{2}{|c|}{ MSY-RB } & \multicolumn{2}{|c|}{ IZAÑA-HA } \\
\hline & WKs & WEs & WKs & WEs & WKs & WEs & WKs & WEs & WKs & WEs & WKs & WEs & WKs & WEs \\
\hline \multicolumn{15}{|c|}{ Warm REDMAAS field campaign } \\
\hline$N_{t o t}$ & $\begin{array}{c}8134 \\
( \pm 4943)\end{array}$ & $\begin{array}{c}9000 \\
( \pm 4595)\end{array}$ & $\begin{array}{c}4216 \\
( \pm 1136)\end{array}$ & $\begin{array}{c}4087 \\
( \pm 853)\end{array}$ & & & & & $\begin{array}{c}8877 \\
( \pm 4007)\end{array}$ & $\begin{array}{c}9324 \\
( \pm 3450)\end{array}$ & $\begin{array}{c}5798 \\
( \pm 3241)\end{array}$ & $\begin{array}{c}6520 \\
( \pm 3799)\end{array}$ & $\begin{array}{c}809 \\
( \pm 743)\end{array}$ & $\begin{array}{c}1192 \\
( \pm 1187)\end{array}$ \\
\hline $\begin{array}{c}\text { WEs/WKs } \\
\text { difference (\%) }\end{array}$ & & 11 & & -3 & & & & & & 5 & & 12 & & 47 \\
\hline$N_{n u c}$ & $\begin{array}{c}5337 \\
( \pm 4712)\end{array}$ & $\begin{array}{c}5575 \\
( \pm 5072)\end{array}$ & $\begin{array}{c}1095 \\
( \pm 734)\end{array}$ & $\begin{array}{c}1209 \\
( \pm 722)\end{array}$ & & & & & $\begin{array}{c}3867 \\
( \pm 2826)\end{array}$ & $\begin{array}{c}4254 \\
( \pm 3017)\end{array}$ & $\begin{array}{c}1300 \\
( \pm 1158)\end{array}$ & $\begin{array}{c}1602 \\
( \pm 1682)\end{array}$ & $\begin{array}{c}447 \\
( \pm 554)\end{array}$ & $\begin{array}{c}769 \\
( \pm 970)\end{array}$ \\
\hline $\begin{array}{l}\text { WEs/WKs } \\
\text { difference (\%) }\end{array}$ & & 4 & & 10 & & & & & & 10 & & 23 & & 72 \\
\hline$N_{\text {Ait }}$ & $\begin{array}{c}2306 \\
( \pm 416)\end{array}$ & $\begin{array}{c}2486 \\
( \pm 987)\end{array}$ & $\begin{array}{c}2221 \\
( \pm 523)\end{array}$ & $\begin{array}{c}2034 \\
( \pm 390)\end{array}$ & & & & & $\begin{array}{c}4286 \\
( \pm 1298)\end{array}$ & $\begin{array}{c}4377 \\
( \pm 753)\end{array}$ & $\begin{array}{c}3125 \\
( \pm 1823)\end{array}$ & $\begin{array}{c}3302 \\
( \pm 1924)\end{array}$ & $\begin{array}{c}280 \\
( \pm 178)\end{array}$ & $\begin{array}{c}340 \\
( \pm 212)\end{array}$ \\
\hline $\begin{array}{c}\text { WEs/WKs } \\
\text { difference (\%) }\end{array}$ & & 8 & & -8 & & & & & & 2 & & 6 & & 21 \\
\hline$N_{a c c}$ & $\begin{array}{c}491 \\
( \pm 88)\end{array}$ & $\begin{array}{c}924 \\
( \pm 791)\end{array}$ & $\begin{array}{c}903 \\
( \pm 128)\end{array}$ & $\begin{array}{c}845 \\
( \pm 169)\end{array}$ & & & & & $\begin{array}{l}724 \\
( \pm 86)\end{array}$ & $\begin{array}{c}694 \\
( \pm 87)\end{array}$ & $\begin{array}{c}1373 \\
( \pm 333)\end{array}$ & $\begin{array}{c}1616 \\
( \pm 380)\end{array}$ & $\begin{array}{c}83 \\
( \pm 18)\end{array}$ & $\begin{array}{c}84 \\
( \pm 18)\end{array}$ \\
\hline $\begin{array}{c}\text { WEs/WKs } \\
\text { difference (\%) }\end{array}$ & & 88 & & -6 & & & & & & -4 & & 18 & & 1 \\
\hline \multicolumn{15}{|c|}{ Cold REDMAAS field campaign } \\
\hline$N_{t o t}$ & $\begin{array}{c}3497 \\
( \pm 1633)\end{array}$ & $\begin{array}{c}2122 \\
( \pm 1250)\end{array}$ & $\begin{array}{c}8600 \\
( \pm 2105)\end{array}$ & $\begin{array}{c}6187 \\
( \pm 724)\end{array}$ & $\begin{array}{c}7894 \\
( \pm 2962)\end{array}$ & $\begin{array}{c}7253 \\
( \pm 3176)\end{array}$ & $\begin{array}{c}13307 \\
( \pm 5422)\end{array}$ & $\begin{array}{c}7593 \\
( \pm 2617)\end{array}$ & $\begin{array}{c}4216 \\
( \pm 1136)\end{array}$ & $\begin{array}{c}4087 \\
( \pm 853)\end{array}$ & $\begin{array}{c}2028 \\
( \pm 832)\end{array}$ & $\begin{array}{c}1736 \\
( \pm 836)\end{array}$ & $\begin{array}{c}555 \\
( \pm 488)\end{array}$ & $\begin{array}{c}486 \\
( \pm 351)\end{array}$ \\
\hline $\begin{array}{c}\text { WEs/WKs } \\
\text { difference (\%) }\end{array}$ & & -39 & & -28 & & -8 & & -43 & & -3 & & -14 & & -12 \\
\hline$N_{\text {nuc }}$ & $\begin{array}{c}1715 \\
( \pm 962)\end{array}$ & $\begin{array}{c}1074 \\
( \pm 629)\end{array}$ & $\begin{array}{c}1166 \\
( \pm 480)\end{array}$ & $\begin{array}{l}570 \\
( \pm 99)\end{array}$ & $\begin{array}{c}2937 \\
( \pm 1331)\end{array}$ & $\begin{array}{c}2620 \\
( \pm 1199)\end{array}$ & $\begin{array}{c}2637 \\
( \pm 1467)\end{array}$ & $\begin{array}{c}2014 \\
( \pm 902)\end{array}$ & $\begin{array}{c}1095 \\
( \pm 734)\end{array}$ & $\begin{array}{c}1209 \\
( \pm 722)\end{array}$ & $\begin{array}{c}550 \\
( \pm 300)\end{array}$ & $\begin{array}{c}570 \\
( \pm 326)\end{array}$ & $\begin{array}{c}277 \\
( \pm 336)\end{array}$ & $\begin{array}{c}232 \\
( \pm 224)\end{array}$ \\
\hline $\begin{array}{c}\text { WEs/WKs } \\
\text { difference (\%) }\end{array}$ & & -37 & & -51 & & -11 & & -24 & & 10 & & 4 & & -16 \\
\hline$N_{\text {Ait }}$ & $\begin{array}{c}1322 \\
( \pm 576)\end{array}$ & $\begin{array}{c}779 \\
( \pm 474)\end{array}$ & $\begin{array}{c}5166 \\
( \pm 1376)\end{array}$ & $\begin{array}{c}3520 \\
( \pm 528)\end{array}$ & $\begin{array}{c}3727 \\
( \pm 1432)\end{array}$ & $\begin{array}{c}3469 \\
( \pm 1605)\end{array}$ & $\begin{array}{c}8189 \\
( \pm 3319)\end{array}$ & $\begin{array}{c}4570 \\
( \pm 1545)\end{array}$ & $\begin{array}{c}2221 \\
( \pm 523)\end{array}$ & $\begin{array}{c}2034 \\
( \pm 390)\end{array}$ & $\begin{array}{c}950 \\
( \pm 340)\end{array}$ & $\begin{array}{c}811 \\
( \pm 402)\end{array}$ & $\begin{array}{c}223 \\
( \pm 131)\end{array}$ & $\begin{array}{c}204 \\
( \pm 117)\end{array}$ \\
\hline $\begin{array}{c}\text { WEs/WKs } \\
\text { difference (\%) }\end{array}$ & & -41 & & -32 & & -7 & & -44 & & -8 & & -15 & & -9 \\
\hline Nacc & $\begin{array}{c}460 \\
( \pm 146)\end{array}$ & $\begin{array}{c}268 \\
( \pm 158)\end{array}$ & $\begin{array}{c}2268 \\
( \pm 326)\end{array}$ & $\begin{array}{c}2097 \\
( \pm 188)\end{array}$ & $\begin{array}{c}1229 \\
( \pm 293)\end{array}$ & $\begin{array}{c}1164 \\
( \pm 485)\end{array}$ & $\begin{array}{c}2480 \\
( \pm 746)\end{array}$ & $\begin{array}{c}1010 \\
( \pm 245)\end{array}$ & $\begin{array}{c}903 \\
( \pm 128)\end{array}$ & $\begin{array}{c}845 \\
( \pm 169)\end{array}$ & $\begin{array}{c}528 \\
( \pm 212)\end{array}$ & $\begin{array}{c}355 \\
( \pm 129)\end{array}$ & $\begin{array}{c}55 \\
( \pm 27)\end{array}$ & $\begin{array}{c}51 \\
( \pm 23)\end{array}$ \\
\hline
\end{tabular}



$\mathrm{SR}=$ Solar Radiation and AP=Atmospheric Pressure) at all sites during the REDMAAS field campaigns.

\begin{tabular}{|c|c|c|c|c|c|c|c|}
\hline & ACN-UB & CIEMAT-UB & BCN-UB & GRN-UB & ARN-RB & MSY-RB & IZAÑA-HA \\
\hline \multicolumn{8}{|c|}{ Warm REDMAAS field campaign } \\
\hline $\mathrm{T}\left({ }^{\circ} \mathrm{C}\right)$ & $16.2 \pm 2.5$ & $23.9 \pm 3.8$ & & & $21.8 \pm 2.2$ & $20.7 \pm 3.4$ & $15.7 \pm 3.6$ \\
\hline $\mathrm{RH}(\%)$ & $82 \pm 8$ & $34 \pm 10$ & & & $58 \pm 11$ & $60 \pm 15$ & $35 \pm 14$ \\
\hline WS $\left(m \cdot \mathrm{s}^{-1}\right)$ & $0.6 \pm 0.4$ & $4.1 \pm 1.3$ & & & $5.8 \pm 1.2$ & $0.9 \pm 0.2$ & $8.0 \pm 2.5$ \\
\hline $\mathrm{P}(\mathrm{mm})$ & & 0.5 & & & 0 & 60.6 & \\
\hline $\mathrm{SR}\left(\mathrm{W} \cdot \mathrm{m}^{-2}\right)$ & $219.9 \pm 77.7$ & $291.5 \pm 56.3$ & & & $335.9 \pm 51.3$ & $265.7 \pm 64.7$ & $380.3 \pm 26.5$ \\
\hline $\mathrm{AP}(\mathrm{mbar})$ & $1007.8 \pm 4.5$ & $937.9 \pm 2.6$ & & & $1009.5 \pm 2.0$ & $940.5 \pm 3.7$ & $771.7 \pm 1.6$ \\
\hline \multicolumn{8}{|c|}{ Cold REDMAAS field campaign } \\
\hline $\mathrm{T}\left({ }^{\circ} \mathrm{C}\right)$ & $14.0 \pm 1.2$ & $6.3 \pm 2.9$ & $12.7 \pm 2.0$ & $9.6 \pm 2.4$ & $11.6 \pm 2.0$ & $9.5 \pm 3.4$ & $9.8 \pm 2.4$ \\
\hline RH (\%) & $81 \pm 2$ & $83 \pm 12$ & $66 \pm 10$ & $66 \pm 10$ & $79 \pm 8$ & $61 \pm 18$ & $18 \pm 14$ \\
\hline WS $\left(\mathrm{m} \cdot \mathrm{s}^{-1}\right)$ & $1.0 \pm 0.5$ & $2.7 \pm 1.8$ & $1.9 \pm 0.8$ & $1.1 \pm 0.3$ & $4.5 \pm 1.1$ & $1.2 \pm 1.0$ & $5.7 \pm 2.7$ \\
\hline $\mathrm{P}(\mathrm{mm})$ & & 7.8 & 7.0 & & 4.6 & 12.8 & \\
\hline $\mathrm{SR}\left(\mathrm{W} \cdot \mathrm{m}^{-2}\right)$ & $35.1 \pm 17.1$ & $54.9 \pm 35.0$ & $84.4 \pm 24.0$ & & $99.9 \pm 37.9$ & $76.5 \pm 22.2$ & $195.1 \pm 14.5$ \\
\hline AP (mbar) & $1005.2 \pm 7.3$ & $944.6 \pm 5.9$ & $1009.6 \pm 6.2$ & & $1018.9 \pm 4.7$ & $942.8 \pm 6.2$ & $771.0 \pm 1.9$ \\
\hline
\end{tabular}


24 Table S7. Overview of the main meteorological aspects (T=ambient temperature, RH=relative humidity, WS=wind speed, 25 prevailing $\mathrm{WD}(\mathrm{s})=$ prevailing wind direction(s), $\mathrm{SR}=$ solar irradiance) and calculated parameters (GR and ER=growth and 26 evaporation rates) for the aerosol particle shrinkages events found during the warm REDMAAS field campaign at CIEMAT-UB,

27 ACN-UB and ARN-RB.

\begin{tabular}{|c|c|c|c|c|c|c|c|c|c|c|c|c|c|c|c|c|c|c|}
\hline \multirow[b]{2}{*}{ Site } & \multirow[b]{2}{*}{ Start Day } & \multicolumn{9}{|c|}{ Previous phase to the shrinkage } & \multicolumn{8}{|c|}{ Shrinkage phase } \\
\hline & & Phase & Period & Durantion & $\begin{array}{c}\text { GR } \\
\left(\mathrm{nm} \cdot \mathrm{h}^{-1}\right)\end{array}$ & $\begin{array}{c}\mathrm{T} \\
\left({ }^{\circ} \mathrm{C}\right)\end{array}$ & $\begin{array}{l}\text { RH } \\
(\%)\end{array}$ & $\begin{array}{c}\text { WS } \\
\left(\mathrm{m} \mathrm{s}^{-1}\right)\end{array}$ & $\begin{array}{c}\text { Prevailing } \\
\text { WD(s) }\end{array}$ & 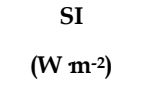 & Period & Duration & $\begin{array}{c}\text { ER } \\
\left(\mathrm{nm} \cdot \mathbf{h}^{-1}\right)\end{array}$ & $\begin{array}{c}\mathrm{T} \\
\left({ }^{\circ} \mathrm{C}\right)\end{array}$ & $\begin{array}{l}\text { RH } \\
(\%)\end{array}$ & $\begin{array}{c}\text { WS } \\
\left(\mathrm{m} \mathrm{s}^{-1}\right)\end{array}$ & $\begin{array}{c}\text { Prevailing } \\
\text { WD(s) }\end{array}$ & 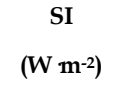 \\
\hline \multirow{7}{*}{ 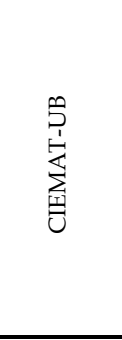 } & \multirow{2}{*}{$10 / 06 / 2012$} & \multirow{2}{*}{ NPF(Ia) } & $8: 00-10: 20$ & 2.33 & 4.9 & $25.0 \pm 1.4$ & $28 \pm 3$ & $3.3 \pm 1.3$ & WSW-W & $654 \pm 113$ & 10:20-11:00 & 0.67 & -3.4 & $28.1 \pm 0.5$ & $23 \pm 1$ & $3.0 \pm 0.4$ & WSW & $851 \pm 20$ \\
\hline & & & 11:00-13:00 & 2 & 6.2 & $29.8 \pm 0.5$ & $19 \pm 1$ & $2.8 \pm 0.7$ & WSW & $910 \pm 11$ & 13:00- 14:50 & 1.83 & -6.6 & $31.7 \pm 0.5$ & $15 \pm 1$ & $2.3 \pm 0.9$ & W-WSW & $794 \pm 84$ \\
\hline & $30 / 06 / 2012$ & NPF(Ia) & 13:40-16:30 & 2.83 & 5.3 & $25.0 \pm 0.4$ & $22 \pm 1$ & $6.4 \pm 0.1$ & WSW-SW & $770 \pm 110$ & $16: 30-19: 20$ & 2.83 & -6.4 & $24.3 \pm 0.8$ & $21 \pm 2$ & $6.5 \pm 1.3$ & NW-WNW & $226 \pm 186$ \\
\hline & $05 / 06 / 2012$ & G & 21:50-22:40 & 1.83 & 5.9 & $24.4 \pm 0.2$ & $34 \pm 2$ & $5.5 \pm 0.8$ & WNW & 0 & 22:40-00:00 & 1.33 & -10.4 & $23.3 \pm 0.4$ & $42 \pm 4$ & $4.4 \pm 0.4$ & WNW & 0 \\
\hline & $14 / 06 / 2012$ & G & $21: 10-22: 20$ & 1.16 & 3.5 & $23.7 \pm 0.5$ & $31 \pm 4$ & $3.3 \pm 0.6$ & $\mathrm{~W}$ & 0 & $22: 20-00: 30$ & 2.17 & -7.3 & $22.1 \pm 0.5$ & $39 \pm 1$ & $4.1 \pm 0.7$ & W-SW-WSW & 0 \\
\hline & 06/06/2012 & & & & & & & & & & 16:00-23:50 & 6.83 & -4.3 & $26.2 \pm 1.8$ & $37 \pm 8$ & $6.2 \pm 2.6$ & WSW-SW & $119 \pm 201$ \\
\hline & $29 / 06 / 2012$ & & & & & & & & & & $16: 20-20: 00$ & 3.67 & -2.2 & $27.3 \pm 1.0$ & $19 \pm 2$ & $7.2 \pm 0.9$ & WSW-SW & $230 \pm 222$ \\
\hline ACN-UB & $18 / 06 / 2012$ & & & & & & & & & & 19:30-21:30 & 2 & -2.8 & $15.2 .6 \pm 0.3$ & $81.3 \pm 0.5$ & $0.6 \pm 0.3$ & & $48.0 \pm 59.8$ \\
\hline \multirow{12}{*}{$\frac{\infty}{\frac{a}{2}}$} & $12 / 06 / 2012$ & NPF(Ia) & 10:50- 14:50 & 4 & 6.5 & $26.5 \pm 1.3$ & $26 \pm 2$ & $6.0 \pm 0.3$ & NNE-NE & $1002.6 \pm 57.1$ & 14:50- 15:40 & 0.8 & -9.6 & 23.2 & 49 & 7.3 & $\mathrm{~W}$ & 775 \\
\hline & $04 / 06 / 2012$ & & & & & & & & & & $22: 00-23: 50$ & 1.8 & -6.3 & $23.7 \pm 0.7$ & $57 \pm 3$ & $8.0 \pm 0.4$ & $\mathrm{~N}$ & 0 \\
\hline & $05 / 06 / 2012$ & & & & & & & & & & 21:30-23:30 & 2.0 & -2.2 & $24.0 \pm 1.1$ & $58 \pm 6$ & $7.0 \pm 1.3$ & NNW-N & 0 \\
\hline & $06 / 06 / 2012$ & & & & & & & & & & 22:50-00:40 & 2.6 & -2.8 & $20.8 \pm 0.5$ & $69 \pm 1$ & $4.4 \pm 0.2$ & NNW & 0 \\
\hline & $09 / 06 / 2012$ & & & & & & & & & & 21:40-23:50 & 2.2 & -11.4 & $21.8 \pm 0.7$ & $57 \pm 4$ & $7.8 \pm 1.2$ & NNW-N & 0 \\
\hline & $10 / 06 / 2012$ & & & & & & & & & & 20:50-2:20 & 5.5 & -4.7 & $21.7 \pm 2.0$ & $59 \pm 4$ & $6.4 \pm 1.0$ & NNW-N & 0 \\
\hline & $11 / 06 / 2012$ & & & & & & & & & & 18:10-23:00 & 4.8 & -4.5 & $22.9 \pm 2.1$ & $37 \pm 3$ & $7.1 \pm 1.0$ & NNW & $42.5 \pm 81.6$ \\
\hline & $14 / 06 / 2012$ & & & & & & & & & & $21: 50-23: 30$ & 1.7 & -3.7 & $22.4 \pm 0.8$ & $51 \pm 1$ & $6.4 \pm 0.3$ & $N$ & 0 \\
\hline & $15 / 06 / 2012$ & & & & & & & & & & 21:40-00:50 & 3.2 & -7.7 & $23.0 \pm 1.5$ & $57 \pm 6$ & $8.1 \pm 0.2$ & $\mathrm{~N}$ & 0 \\
\hline & $17 / 06 / 2012$ & & & & & & & & & & $19: 50-23: 40$ & 3.8 & -5.5 & $16.3 \pm 0.3$ & $83 \pm 2$ & $2.4 \pm 0.1$ & s & 0 \\
\hline & $22 / 06 / 2012$ & & & & & & & & & & 23:00- 1:50 & 2.8 & -4.4 & $21.9 \pm 0.8$ & $37 \pm 1$ & $7.9 \pm 0.8$ & $\mathrm{~N}$ & 0 \\
\hline & $28 / 06 / 2012$ & & & & & & & & & & 22:50- 3:00 & 4.2 & -8.1 & $20.8 \pm 1.3$ & $62 \pm 3$ & $6.5 \pm 0.7$ & NNW & 0 \\
\hline
\end{tabular}


References

29 Gómez-Moreno, F.J., Alonso, E., Artíñano, B., Juncal-Bello, V., Iglesias-Samitier, S., Piñeiro Iglesias, M., Mahía, P.L., Pérez, N., 30 Pey, J., Ripoll, A., 2015. Intercomparisons of Mobility Size Spectrometers and Condensation Particle Counters in the Frame of the Spanish Atmospheric Observational Aerosol Network. Aerosol Science and Technology 49, 777-785. 